\title{
Oogheelkunde in de huisartspraktijk
}

Citation for published version (APA):

Baggen, J. L. (1990). Oogheelkunde in de huisartspraktijk. [Doctoral Thesis, Maastricht University]. [s.n.]. https://doi.org/10.26481/dis.19900118jb

Document status and date:

Published: 01/01/1990

DOI:

10.26481/dis.19900118jb

Document Version:

Publisher's PDF, also known as Version of record

\section{Please check the document version of this publication:}

- A submitted manuscript is the version of the article upon submission and before peer-review. There can be important differences between the submitted version and the official published version of record.

People interested in the research are advised to contact the author for the final version of the publication, or visit the DOI to the publisher's website.

- The final author version and the galley proof are versions of the publication after peer review.

- The final published version features the final layout of the paper including the volume, issue and page numbers.

Link to publication

\footnotetext{
General rights rights.

- You may freely distribute the URL identifying the publication in the public portal. please follow below link for the End User Agreement:

www.umlib.nl/taverne-license

Take down policy

If you believe that this document breaches copyright please contact us at:

repository@maastrichtuniversity.nl

providing details and we will investigate your claim.
}

Copyright and moral rights for the publications made accessible in the public portal are retained by the authors and/or other copyright owners and it is a condition of accessing publications that users recognise and abide by the legal requirements associated with these

- Users may download and print one copy of any publication from the public portal for the purpose of private study or research.

- You may not further distribute the material or use it for any profit-making activity or commercial gain

If the publication is distributed under the terms of Article $25 \mathrm{fa}$ of the Dutch Copyright Act, indicated by the "Taverne" license above, 
OOGHEELKUNDE IN DE HUISARTSPRAKTIJK 



\section{OOGHEELKUNDE IN DE HUISARTSPRAKTIJK}

\section{PROEFSCHRIFT}

ter verkrijging van de graad van doctor aan de Rijksuniversiteit Limburg te Maastricht, op gezag van de Rector Magnificus, Prof. Dr. F.I.M. Bonke, volgens het besluit van het College van Dekanen, in het openbaar te verdedigen op donderdag, 18 januari 1990 om 16.00 uur

door

Josephus Leonardus Baggen

geboren te Schinveld in 1929 
Promotores:

Prof, dr. F.J.A. Huygen

Prof. dr. W.P.M.A. Lamers

Beoordelingscommissie: Prof. dr. J.A. Knottnerus (voorzitter)

Prof. dr. A.C. Breebaart

Prof. dr. G.J. Bremer

Prof. dr. H.J.F.M. Crebolder

Prof. dr. F. Sturmans

Dit proefschrift kwam mede tot stand dankzij de steun van het Preventiefonds 
Voor en met Contessa Vermicelli 


\section{Voorwoord}

Een voorwoord wordt meestal het allerlaatst geschreven. Zo ook in dit geval. Pas achteraf is men in staat de lezer met enkele pennestreken een indruk te geven wan de afgelegde weg.

Dit proefschrift wordt verdedigd tegen het einde van mijn loopbaan als huisarts, die op 1 oktober 1961 in Brunssum begon. Het nu voltooide onderzoek ligt rechtstreeks in het verlengde van mijn denken en handelen als huisarts. Van meet af aan was ik niet tevreden over de mogelijkheden van vroegdiagnostiek van ernstige ziekten in de eerste lijn van de gezondheidszorg. Het grote probleem voor de huisarts is en blijft, dat de eerste symptomen van ernstige ziekte zich niet onderscheiden van die van een griepje of een nacht slecht slapen. De - op de specialistische geneeskunde geënte leerboeken bieden hierbij weinig houvast. Accepteren van onzekerheden is onontbeerlijk bij het diagnostisch handelen in de huisartsgeneeskunde. Vermijden van schijnzekerheden echter evenzeer.

Ideeën over "noodzakelijk en voldoende" in denken en handelen, kristaliseerden zich in de loop der jaren uit. De weg waarlangs ze tot stand kwamen, is amper te reconstrueren. Het was een samenspel van waarnemen, redeneren, afschaffen van oude gewoontes en uitproberen van nieuwe.

Het was ook een samenspel met anderen, speciaal met mijn collega en associé, Thijs Vaessen, die evenzeer als ik het accent wilde leggen op preventie en vroegdiagnostiek. Een nieuwe benadering werd gekozen op het gebied van hart- en vaat-ziektem, chronische longziekten, diabetes, gehoor-stoornissen en oogziekten.

Dit proefschrift is de weerslag van onze werkwijze op het gebied van de huisartsgeneeskundige oogheelkunde.

Aan Wiel Lamers is het te danken, dat het door mij verzameld feitenmateriaal op expertise berustte en voor wetenschappelijk onderzoek bruikbaar was. Ik waardeer het bijzonder, dat hij, hoewel kritisch, mijn ijveren voor een volwaardige scholing van huisartsen in de oogheelkunde ondersteunde en dit idee ook tegenover anderen propageerde.

Het doen van onderzoek was voor mij een kompleet nieuwe ervaring. Zelfs een woord als "vraagstelling" was mij onbekend en bleef nog lange tijd een leeg begrip, alworens die denkgymnastiek werd opgeroepen die met dit woord werband houdt. Hetzelfde geldt voor woorden als projectvoorstel, onderzoeksprotocol, dubbeltellen en (on)afhankelijke variabele. Kortom, een geheel ander, niet huisarts-geneeskundig vocabulair, dat de communicatie aanvankelijk belemmerde, maar bij nader inzien vernuftig bleek en onontbeerlijk bij het zoeken naar verbanden tussen determinanten en uitkomsten. Het is te danken aan de kameraadschap en de zachtmoedige vasthoudendheid van Frans Huygen, dat ik niet in het moeras ben blijven steken. Ook Henk van den Hoogen bewonder ik achteraf, omdat hij mij telkens weer met alle geduld van de wereld het $\mathrm{ABC}$ van onderzoek uit de doeken deed en op de juiste momenten de nodige humor aan de dag legde. Desalniettemin ervaarde ik het vigerend wetenschappelijk paradigma vaak als een keurslijf, waarin uitkomsten van mijn jarenlang denken en experimenteren vaak als "niet bewezen" dus "als conclusie ongeoorloofd" werden gekwalificeerd. Yvonne weet dat als geen ander. Zij was er steeds bij, dacht mee en schreef mee. Zij heeft al die tijd onvermoeibaar gepleit voor nuanceringen in mijn uitspraken, zonder de kern van mijn ideeën aan te tasten. 
Daarwoor moest zelfs mijn eigenwijsheid door de knieën en ik heb ook steeds volledig op haar oordeel vertrouwd.

Voor het vertalen van de samenvatting in het engels hebben we de NATO ingeschakeld. Je woont tenslotte niet voor niets in Brunssum! Rob de Bruyn, bedankt!

Door dit promotiegebeuren ben ik in contact gekomen met de informatica, dat wil zeggen de computer. Van de een op de andere dag worden ineens zo en zoveel megabytes geheugen voor je neergezet. Mijn aarzeling om ook nog eens met dit schip in zee te gaan werd met flair aan de kant gezet door Cees van der Vleuten, die gewoon naast me ging zitten en niet wegging voor ik zelfstandig verder kon. Het latatste loodje: het verzorgen van de lay-out, heeft hij geheel voor zijn rekening genomen. Men realiseert zich pas goed wat dat betekent, indien men weet dat de ongeveer 80 tabellen die in dit proefschrift voorkomen bijna letterlijk "met de hand gezet" moeten worden. Verloren bestanden, kapotte harde schijven, door virus verminkt materiaal, we hebben het inmiddels allemaal meegemaakt. Dank zij de lankmoedige bereidwillgheid van de computer-leverancier Wolting kon de schade meestal hersteld worden. Mevrouw Jansen en Gertie, onze praktijkassistentes, zullen een zucht van verlichting slaken, nu "het proefschrift" geen telkens terugkerend item meer is, waarmee in meerdere opzichten rekening moest worden gehouden en ook gehouden werd.

Voor mij is dit promoveren geen einde, maar in zekere zin weer een begin. Meer dan ooit ben ik ervan overtuigd, dat de huisarts een veelheid aan adviezen nodig heeft, orm de oogheelkunde goed vorm te geven. Ik zal dan ook een aanzet geven voor een leerboek oogheelkunde voor de huisarts en voor een degelijke cursus voor huisartsopleiders. Verder zal ik mij in woord en geschrift blijven verweren tegen de opvatting, dat het grondig verkennen van een terrein binnen de huisartsgeneeskunde, teneinde al doende vast te stellen, wat des huisarts is en wat niet, als hobbyisme gekenschetst moet worden. De huisartsgeneeskunde kan zich niet permitteren zonder scrutineus onderzoeken van de waarde van nieuwe ontwikkelingen bij een aloud recept te zweren. In de huidige tijd zelfs minder dan ooit. 


\section{Inhoud}

1 Inlleiding 1

2 Oogheelkunde in de huisartspraktijk: stand van zaken 5

2.0 Inleiding 5

2.1 Richtlijnen voor het handelen van de huisarts bij oogheelkundige problemen $\quad 6$

2.2 Verwijscijfers 8

2.3 Het onderwijs in de oogheelkunde 8

2.4 Wetenschappelijk onderzoek met betrekking tot
oogheelkundige problemen in de huisartspraktijk

2.5 Samenvatting en conclusies 13

3 Aanleiding tot het onderzoek en de onderzoeksvragen 15

4 Beschrijving van de praktijk $\quad 17$

5 Methode $r$

$\begin{array}{lll}5.1 & \text { Organisatie } & 19\end{array}$

5.2 De registratieperiode 19

5.3 De wijzen van registreren $\quad 19$

5.4 Rubricering $\quad 19$

$\begin{array}{ll}5.5 & \text { Negatieve diagnostiek } \\ 5.62\end{array}$

$\begin{array}{lll}5.6 & \text { Incidenties } & 22\end{array}$

6 Aard en aantal der consulten

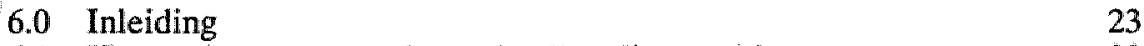

6.1 Het registreren van de oogheelkundige problemen 23

6.2. De oogheelkundige consulten nader bekeken 24

6.3 Controle op de juistheid van de gestelde diagnosen;
verwijzingen en follow-up

6.4 Samenvatting en conclusies 34

7 Morbiditeitsregistraties $\quad 37$

$\begin{array}{lll}7.0 & \text { Inleiding } & 37\end{array}$

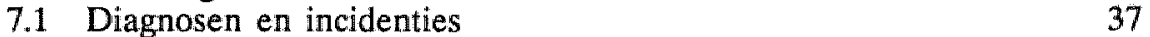

7.2 Vergelijking met andere morbiditeitsregistraties 39

7.3 Analyse van de gegevens uit paragraaf $7.2 \quad 43$

7.4 Samenvatting en conclusies $\quad 47$ 
8 Van kllacht naar diagnose

De reden van oogheelkundig onderzoek in relatie tot de diagnose

$\begin{array}{ll}\text { 8.0 Inleiding } & 49\end{array}$

8.1 Specifieke oogklachten 51

8.2 Bevindingen bij surveillerend oogonderzoek 60

8.3 Beschouwing 65

9 Tussen klacht en bevinding

Instrumentele voorwaarden voor oogdiagnostiek $\quad 67$

$\begin{array}{lll}9.0 & \text { Inleiding } & 67\end{array}$

9.1 De hulpmiddelen $\quad 67$

9.2 De relatie tussen klacht en hulpmiddel 69

9.3 De relatie tussen het gebruik van de spleetlamp en de diagnose

9.4 De relatie tussen het gebruik van de indirecte funduscoop en de diagnose

9.5 De relatie tussen het gebruik van de applanatietonometer en de diagnose

9.6 Samenvatting en conclusies

10 Blindheid en slechtziendheid; morbiditeit en preventie 77

$\begin{array}{lll}10.0 & \text { Inleiding } & 77\end{array}$

10.1 Slechtziendheid en blindheid; invaliditeit door oogziekten 77

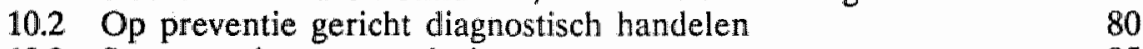

10.3 Samenvatting en conclusies 85

11 Samenvatting van de resultaten, conclusies en beschouwing 87

$\begin{array}{lll}11.0 & \text { Inleiding } & 87\end{array}$

$\begin{array}{lll}11.1 & \text { De resultaten in relatie tot de onderzoeksvragen } & 87\end{array}$

$\begin{array}{ll}11.2 \text { Conclusies } & 91\end{array}$

11.3 Kanttekeningen bij de onderzoeksopzet 91

11.4 Beschouwing en aanbevelingen 92

Samenvatting 95

$\begin{array}{ll}\text { Summary } & 101\end{array}$

$\begin{array}{ll}\text { Literatuur } & 107\end{array}$

Bijlagen 111

I Wijzigingen/aanpassingen Basistakenpakket dd 26-11-1985 111

II Kenmerken van de Huisarts II: de drie kennis- en vaardigheden-
nivos van de huisarts op het gebied van de oogheelkunde

III Computerformulier $\quad 115$

IV Rubriekenlijst $\quad 117$

V Lijst van incidenties 121

VI Restcategorie behorend bij tabel 7.2.- 1, 7.2.- 2 en 7.2.- 3 


\section{Hoofdstuk 1}

\section{INLEIDING}

Ongeveer een vijfde van de verwijzingen van ziekenfondspatiënten vanuit de huisartspraktijk naar de specialist betreft verwijzingen naar de oogarts. De meeste daarvan worden door doktersassistenten afgegeven (NIVEL 1987).

Dit grote aantal verwijzingen, dat veelal zonder vraagstelling of indicatie worden afgegeven, doet de vraag rijzen welke plaats de oogheelkunde heeft binnen het huisartsgeneeskundig handelen.

In de opleiding tot arts wordt oogheelkunde tot de "kleine vakken" gerekend. Het hoge verwijscijfer zou erop kunnen wijzen, dat voor de huisarts de oogheelkunde evenmin tot de grote aandachtsvelden behoort. Literatuurgegevens lijken deze indruk te bevestigen. Sterker nog, de huisarts lijkt de oogheelkunde enigszins uit het zicht te hebben verloren. De vraag in hoeverre een zo bescheiden plaats van de oogheelkunde binnen het huisartsgeneeskundig handelen terecht is, is een interessante vraag. Dit onderzoek is ondermeer bedoeld om hierop een antwoord te geven.

Het oogheelkundig diagnostisch instrumentarium, waarvan de Nederlandse huisarts doorgaans gebruik maakt, verschilt aanzienlijk van dat van de oogarts. Dit is niet zonder meer wanzelfsprekend. Een deel van het instrumentarium van de oogarts ligt wat betreft hanteerbaarheid en betaalbaarheid in principe binnen het bereik van de huisarts. Niet eerder is onderzocht in hoeverre de patiënt gebaat zou zijn bij een uitbreiding van het oogheelkundig instrumentarium van de huisarts met dien verstande, dat oogaandoeningen in een eerder stadium en met grotere zekerheid zouden kunnen worden vastgesteid. Dit onderzoek is mede uitgevoerd om hierop enig zicht te krijgen.

Aan het onderzoek ging een aantal jaren van intensieve scholing in de oogheelkunde vooraf. Deze scholing was vooral daarom zo intensief, omdat literatuur noch ervaring bij collegae-huisartsen veel houvast bood voor het vormgeven van een goede oogheelkunde binnen de huisartspraktijk. Apparatuur werd door de onderzoeker op zicht gevraagd en aangeschaft. Hiermee werden uiteindelijk de beelden verkregen, zoals die voorkomen en worden beschreven in leerboeken oogheelkunde. Door deze 
congruentie tussen theorie en praktijk, die voorheen ontbrak, werd het inzicht in de symptomatologie en het verloop van aandoeningen in hoge mate bevorderd.

Tijdens een tweetal stages op een polikliniek oogheelkunde werden veel kennis en ervaring opgedaan. Door leren en experimenteren ontstond langzamerhand een idee van wat wel maar ook van wat niet zou kunnen bijdragen aan een doelmatige benadering wath oogheelkundige problemen in de huisarts-praktijksetting. Gaandeweg werd het oogheelkundig onderzoek geintegreerd in de dagelijkse praktijkvoering.

Vele aandoeningen werden gediagnostiseerd die voorheen hooguit werden vermoed. Risicogroepen als diabeten en hypertensie-patiënten werden regelmatig gescreend op oogheelkundige complicaties.

De patiënten raakten vertrouwd met het idee, dat verwijzingen naar de oogarts niet meer vanzelfsprekend alleen via de assistente liepen.

Allengs ontstond de behoefte systematisch na te gaan, welke oogheelkundige problemen in de praktijk werden aangeboden en wat het oogheelkundig onderzoek daarbij opleverde. Het opzetten van dit onderzoek was zodoende een vanzelfsprekende volgende stap. Daar het de bedoeling was vooral aandacht te besteden aan de opbrengst van surveillerend oogonderzoek bij risicogroepen en aan de waarde van vroegdiagnostiek werd subsidie bij het Preventiefonds aangevraagd en verkregen.

De indeling van dit proefschrift is als volgt:

In hoofdstuk 2 wordt de stand van zaken betreffende de inhoud van de thuidige huisartsgeneeskundige oogheelkunde geilllustreerd aan de hand van opvattingen van huisartsen, oogartsen en andere speciallisten hierover, zoals verwoord in de literatuur. Tevens wordt een beschrijving gegeven van het aandeel van de oogheelkunde binnen de basisopleiding tot arts en de beroepsopleiding tot huisarts. Tot slot wordt een indruk gegeven van het aandeel van de oogheelkunde binnen de nascholing voor de huisarts, bestaande uit literatuur enerzijds en cursussen en symposia anderzijds.

Hoofdstuk 3 bevat de onderzoeksvragen.

In hoofdstuk 4 wordt de praktijk waarin het onderzoek plaatsvond beschreven en wordt de opbouw van de praktijkpopulatie wat betreft leeftijd en geslacht vergeleken met die van de Nederlandse bevolking.

In hoofdstuk 5 wordt de methode van het onderzoek uiteengezet.

Hoofdstuk 6 presenteert de omvang en de diversiteit van het oogheelkundig probleemaanbod gedurende de registratieperiode. Tevens komt het aantal verwijzingen naar de oogarts en de contróle op de kwaliteit van de gestelde diagnosen aan de orde.

Hoofdstuk 7 bevat de uit het aanbod te destilleren incidentiecijfers van oogaandoeningen, geldend voor deze praktijk. Deze worden vergeleken met de cijfers vit andere morbiditeitsregistraties.

In hoofdstuk 8 worden de uiteindelijk gestelde diagnosen in verband gebracht met hetgeen de aanleiding vormde voor het uitvoeren van het oogheelkundig onderzoek: hetzij een klacht van de patiënt betreffende de ogen, hetzij een bij de arts gevoelde noodzaak om een oogonderzoek te verrichten, bijvoorbeeld bij een diabetespatiënt.

In hoofdstuk 9 komen de gebruikte diagnostische hulpmiddelen in relatie tot de gestelde diagnosen ter sprake. Bijzondere aandacht wordt besteed aan de opbrengst van het onderzoek met de spleetlamp, de indirecte funduscoop en de applanatietonometer.

Hoofdstuk 10 belicht de activiteiten van de arts in het kader van surveillerend oogonderzoek en de opbrengst daarvan. Tevens wordt aandacht besteed aan blindheid 
en slechtziendheid en de daarvoor aan te wijzen oorzaken bij de onderzochte populatie.

In hoofstuk 11 worden de belangrijkste resultaten geresumeerd en besproken evenals de methode van onderzoek. Aanbevelingen worden gedaan voor verder onderzoek en voor het vormgeven van de huisartsgeneeskundige oogheelkunde. 


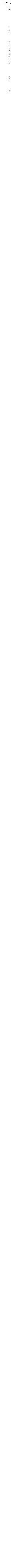




\subsection{Inleiding}

Gegevens die rechtstreeks betrekking hebben op de werkwijze van de Nederlandse huisarts bij oogheelkundige problemen en de daartoe aanwezige praktijkuitrusting zijn niet of nauwelijks voorhanden. Wel kan daaromtrent op indirekte wijze een indruk worden verkregen, bijvoorbeeld door bestudering van de gegeven richtlijnen voor het handelen van de huisarts op oogheelkundig gebied en van de "aanbevolen" kennis en vaardigheden. In dat kader zullen onder andere het Basistakenpakket voor de huisarts (LHV 1983) en het boek Kenmerken II (van Es, de Melker en Goosmann 1983) worden besproken.

Een tweede indicatie voor de stand van zaken wordt gevormd door het verwijscijfer naar de oogarts. Dit verwijscijfer geeft geen rechtstreekse indruk van de mate waarin de huisarts oogheelkundige problemen zelfstandig afhandelt. Het totale oogheelkundig probleemaanbod is immers niet in het cijfer verdisconteerd. Toch wordt het verwijscijfer geregeld als maat gehanteerd voor de kwaliteit van het huisartsgeneeskundig handelen. Enkele gegevens omtrent verwijscijfers zullen worden gepresenteerd.

Bestudering van het door huisartsen genoten onderwijs op het gebied van de oogheelkunde binnen basis- en beroeps-opleiding geeft inzicht in de kennis en kunde van de Nederlandse huisarts, zoals die redelijkerwijze aanwezig geacht mag worden. Uit het nascholingsaanbod aan huisartsen betreffende oogheelkundige onderwerpen is iets af te leiden over de belangstelling van de huisarts voor de oogheelkunde.

Tot slot wordt een overzicht gegeven van het reeds uitgevoerde onderzoek met betrekking tot de oogheel.kunde in de huisartspraktijk.

Medio 1986 is een literatuurstudie gedaan. Allereerst is materiaal verzameld door screening van de laatste 15 jaargangen van niet-specialistische Nederlandse medische tijdschriften en specifieke vakliteratuur voor huisartsen. 
Tevens is literatuur gezocht met behulp van de computer van de bibliotheek van de Rijksuniversiteit Limburg in het Engelse en Duitse taalgebied met als trefwoorden "oogheelkunde" en "huisartsgeneeskunde" in combinatie.

$\mathrm{Na} 1986$ is de literatuur in de Nederlandse niet-specialistische literatuur bijgehouden.

2.1 Richtlijnen voor het handelen van de huisarts bij oogheelkundige problemen

De Landelijke Huisartsen Vereniging formuleerde haar opwattingen omtrent de taken van de huisarts op oogheelkundig gebied in 1983 heel expliciet in het Basistakenpakket van de huisarts (LHV 1983). Hierin worden de van de huisarts te verwachten oogheelkundige vaardigheden aldus geformuleerd:

- het bepalen van de visus bij volwassenen.

- het onderzoek door middel van inspectie en palpatie naar witwendig te beoordelen oogafwijkingen van oogleden, oogbol, conjunctivae, sklerae, traansysteem, iris en pupil

- het onderzoek naar uitwendig te beoordelen oogafwijkingen door middel van globale gezichtsveldbepaling en door middel van ophthalmoscopie van de lens, het glasvocht en de fundus.

- het globale onderzoek van afwijkingen in oogstand, oogbewegingen en kleuronderscheidingsvermogen.

In de toelichting wordt opgemerkt, dat de huisarts een aantal vaardigheden, zoals funduscopie en tonometrie door diverse oorzaken, o.a. door onvoldoende routine, onvoldoende uitrusting en onvoldoende opleiding, niet altijd optimaal beheerst.

In de nota "Aanvullingen op het Basistakenpakket" (LHV 1985) wordt een aantal oogheelkundige verrichtingen aangemerkt als facultatief. Een facultatieve taak wordt omschreven als een taak die kennis en vaardigheid vereist, welke niet in thet onderwijspakket aan aanstaande (huis)artsen is opgenomen. Hieronder vallen volgens de nota:

het aanmeten van brillen (op enkele moeilijke gevallen na) en het voorafgaand hieraan uitsluiten van andere pathologie dan refractieafwijkingen.

Aangegeven wordt welk instrumentarium men hiervoor nodig acht. De exacte omschrijving van de facultatieve taken en het hiervoor benodigde instrumentarium worden weergegeven in bijlage I.

Van Es, de Melker en Goosmann (1983) onderscheiden in "Kenmerken van de Huisarts II" drie kennis- en vaardighedennivos:

nivo 1: (oog-yziekten die de huisarts zelfsiandig moet kunnen diagnostiseren en behandelen.

nivo 2: (oog-)ziekten die de huisarts in zijn/haar differentiaaldiagnose moet kunnen opnemen en na overleg met de oogarts zelf afhandelen.

niwo 3: (oog-)ziekten die de huisarts in zijn/haar differentiaaldiagnose moet kunnen opnemen waarbij hij/zij moet kumnen aangeven in hoeverre deze "pluis" dan wel "niet pluis" zijn.

Het overzicht van de genoemde oogziekten behorende bij de drie nivo's is opgenomen in bijlage II. 
Tan bespreekt in haar dissertatie: "Tekorten in de opleiding tot huisarts" (Tan 1989) de uitkomst van een panelonderzoek onder 102 huisartsen werkzaan aan een huisartsinstituut. Het panel spreekt zich onder andere uit over het pakket aan kennis en waardigheden op oogheelkundig gebied, dat de huisarts zich tijdens basis- en beroepsopleiding zou moeten verwerven. Bij $80 \%$ overeenstemming tussen de panelleden over de noodzaak het onderwerp in het onderwijs op te nemen, wordt het oordeel "positief" genoemd. De voor het onderzoek gebruikte lijst van ziektebeelden en syndromen is gebaseerd op het rapport Kenmerken II. Het panel is van oordeel, dat alle in het rapport Kenmerken II genoemde aandoeningen in het theoretisch gedeelte van het basisonderwijs aan de orde moeten komen ( 28 aandoeningen). Slechts zes daarvan, dienen volgens het panel ook in de huisartsopleiding, hetzij in theorie, hetzij in de praktijk, hetzij beide, aan de orde te komen. Deze zogenaamde "huisartsitems", zijn de volgende zes:

conjunctivitis, blefaritis, hordeolum, niet perforerend corpus alienum, lasogen, glaucoom.

Wat de vaardigheden betreft, worden van de 24 opgesomde vaardigheden er 12 aangemerkt als "huisartsitem", te weten:

omklappen van de oogleden; inspectie met behulp van lamp/loep en ophthatmoscopisch onderzoek van respectievelijk: conjunctiva, comea, sclera, iris en pupil; onderzoek comea met behulp van fluoresceinestrips; onderzoek van de oogstand (latent strabismus, aantonen met de afdekproef); bepalen van de visus; roestring verwijderen d.m.v. uitkrabben/boortje; oogverband aanleggen.

Uitspraken omtrent het oogheelkundig takenpakket gedaan door individuele huisartsen, zijn in de literatuur slechts sporadisch te vinden. Bremer (1970) en Smit (1986) pleiten voor meer aandacht van de huisarts voor oogheelkundige problematiek. De laatste auteur noemt de oogheelkunde "een groot vak van een klein orgaan".

Enkele huisartsen pleiten voor een betere aanpak van een aantal specifieke oogheelkundige problemen, waaronder glaucoom, cataract en diabetische retinopathie (van Rens 1976, Nolet en Prick-Slothouwer 1978, van Weel 1979, Karmal e.a. 1986, van den Bosch 1986, van de Kar 1988).

Oogartsen lijken evenmin geneigd om hun opvattingen over het oogheelkundig takenpakket van de huisarts op schrift te stellen. Niet én artikel werd gevondlen, waarin een oogarts zich hierover expliciet uitspreekt. Wel wordt ook door enkele oogartsen de taak van de huisarts bif de opsporing van een aantal specifieke aandoeningen besproken (Hagedoorn 1968, Crone 1972, Henkes en van Balen 1983, Lamers 1986; in Engeland o.a.: Bain 1977, Bulger 1981 Fielder 1985).

Samenvattend kan het volgende worden gesteld:

In het Basistakenpakket van de Landelijke Huisartsen Vereniging wordt een opsomming gegeven van het oogheelkundig onderzoek dat de huisarts zou moeten beheersen. Facultatieve taken worden apart vermeld. De voor witvoering van het omschreven onderzoek noodzakelijke vaardigheden zijn niet steeds exact omschreven. Meerdere malen wordt de term "globaal onderzoek" gebezigd, zonder dat precies wordt aangegeven wat hieronder wordt verstaan. 
In Kenmerken II worden aandoeningen die de huisarts moet kennen met name genoemd en ingedeeld in nivo's. Voor elk nivo worden aparte richtlijnen voor het beleid gegeven. Richtlijnen voor diagnostiek, noodzakelijk om onderscheid te kunnen maken tussen de diverse niwo"s, worden echter niet gegeven.

Het panelonderzoek van Tan levert een summiere lijst van oogheelkundige aandoeningen en vaardigheden $\mathrm{op}_{*}$ die als "huisartsitems" worden aangemerkt. Bepaalde delen van het volledig oogonderzoek vallen hier geheel buiten, zoals oogdrukmeting en fundoscopie.

Buiten de hier vermelde rapporten bestaat nauwelijks literatuur, waarin richtlijnen voor het bandelen van de huisarts worden gegeven.

\subsection{Verwijscijfers}

Onder het verwijsciffer naar de oogarts wordt verstaan het aantal verwijzingen per 1000 ziekenfondsverzekerden. Het landelijk gemiddelde hiervan, evenals het landelijk gemiddelde van verwijzingen naar alle specialismen tesamen wordt in tabel 2.2.- 1 weergegeven voor een aantal jaren uit de laatste twee decennia (Post 1986, 1989).

Tabel 2.2.- 1: Aantal verwijzingen per 1000 ziekenfordswerzekerden door hwisantsen natar oogartsen vergeleken met het tolaal der verwijzingen.

\begin{tabular}{ccc} 
Jaar & Oogarts & Totaal \\
\hline 1975 & 122 & 486 \\
1976 & 113 & 491 \\
1980 & 116 & 508 \\
1982 & 110 & 520 \\
1984 & 99 & 495 \\
1986 & 101 & 520
\end{tabular}

Uit deze cijfers blijkt dat het verwijscijfer naar de oogarts ongeveer een vijfde van het totaal der verwijzingen uitmaakt. Er blijkt overigens ook uit, dat het aantal verwijzingen een lichte daling vertoont, terwijl dat niet het geval is voor het totaal der verwijzingen.

Uit het onderzoek van Post (Post 1986) blijkt verder, dat in 1975 een oogarts gemiddeld 3.277 verwijskaarten kreeg. In 1984 was dit afgenomen tot 2.575 . Het totaal aantal verrichtingen van oogartsen nam in die tijd echter met $122 \%$ toe, terwijl het aantal oogartsen min of meer gelijk bleef.

Het hoge verwijscijfer betreffende de oogheelkunde roept vragen op ten aanzien van het handelen van huisartsen bij oogheelkundige problemen en verleent onderzoek naar de oogheelkundige morbiditeit in de huisartspraktijk een extra rechtvaardiging.

\subsection{Het onderwijs in de oogheelkunde}

Het onderwijs in de oogheelkunde aan (aanstaande) huisartsen vindt plaats binnen de kaders, die in de navolgende hoofdstukken aan de orde komen, te weten:

- de opleiding tot basisarts (2.3.1)

- de specifieke beroepsopleiding tot huisarts (2.3.2)

- de georganiseerde nascholing (2.3.3)

- de literatuur (2.3.4) 


\subsubsection{De opleiding tot basisarts}

Oogheelkunde vormt samen met keel- neus- en oor-heelkunde en dermatologie binnen de opleiding tot basisarts het cluster van de zogenaamde "kleine vakken". Dit komt onder meer tot uiting in de tijd die deze vakken is toebedeeld in het kader van de coassistentschappen. Binnen de klassieke curricula wordt in de eerste vier jaren in wisselende mate aandacht besteed aan het theoretisch onderwijs in de oogheelkunde. In Nijmegen wordt in het derde en vierde jaar een serie colleges in de oogheelkunde. aangeboden. In Maastricht wordt ongeveer $0.3 \%$ van de totale onderwijstijd in de eerste vier jaar besteed aan oogheelkundige problematiek, die verspreid over verschillende blokken wordt aangeboden (l'Espoir e.a. 1988). Het praktisch onderwijs in de oogheelkunde beslaat binnen de klassieke curricula in de pre-doctorale fase enkele dagdelen. Maastricht heeft binnen het skillslab-programma ruimschoots plaats ingeruimd voor basale oogheelkundige vaardigheden. Toch geven studenten $n_{n}$ die het co-schap huisartsgeneeskunde in Maastricht hebben doorlopen, aan, dat oogheelkunde tot een van de drie vakken behoort (naast neurologie en dermatologie) die zij naar hun mening bij aanvang van het coassistentschap onvoldoende beheersen (Wolfhagen. 1988).

Het coassistentschap oogheelkunde beslaat aan de medische faculteiten gemiddeld drie weken. In Maastricht wordt het doel daarvan als volgt omschreven:

- de student moet op basis van anamnese en oogheelkundig onderzoek tot een (differentiaal) diagnose kunnen komen. Bij het onderzoek moet gebruik worden gemaakt van oogspiegel en spleetlamp.

- de student moet leren welke oogheelkundige klachten en aandoeningen door de huisarts kunnen worden behandeld en welke klachten tot een verwijzing naar de oogarts leiden.

- de student moet leren welke mogelijkheden de moderne oogheelkunde op diagnostisch en therapeutisch gebied te bieden heeft.

- de student moet bekend raken met de meest gebruikte therapieën zowel operatief als medicamenteus (Rijksuniversiteit Limburg 1987).

In hoeverre deze doelstellingen worden gehaald is niet bekend. Uit het reeds aangehaalde landelijke onderzoek van Tan (Tan 1989) blijkt, dat het aanbod aan onderwijs in oogheelkundige vaardigheden laag is in vergelijking met dat in andere vaardigheden.

\subsubsection{Onderwijs in de oogheelkunde binnen de beroepsopleiding tot huisarts}

Moeilijk is na te gaan, van welke omvang en van welk gehalte het onderwijs in de oogheelkunde is binnen de huisartsopleiding. De huisarts in opleiding brengt immers het grootste gedeelte van de opleiding door in de huisartspraktijk waar hij/zij wordt gesuperviseerd door een huisartsopleider. De aandacht die deze besteedt aan oogheelkundige problemen is mede bepalend voor het nivo van kennis" en vaardigheden dat de huisarts in opleiding behaalt. Ook in het kader van instituutsonderwijs, onderwijs plaatshebbend op de zogenaamde "terugkomdagen", wordt aandacht aan de oogheelkunde besteed; echter niet meer dan enkele dagdelen. Daarin worden enkele capita selecta behandeld. Het rode oog is daarbij favoriet. Slechts enkele vaardigheden komen op een aantal instituten aan de orde; verwijderen wan een corpus alienum en uitboren van een roestring zijn nagenoeg de enige systematisch gedoceerde vaardigheden. 
Uit het onderzoek van Tan blijkt, dat de aangegeven behoefte aan scholing. betreffende ooghelkundige vaardigheden zowel aan het begin als gedurende de huisartsopleiding het hoogst is van alle vaardigheden.

Resumerend kan men stellen, dat het reguliere onderwijs aan huisartsen, bestaande uit basis- en beroeps-opleiding, een summier pakket aan "oogheelkunde" bevat. Voor de aanstaande huisarts kan men dit pakket gerust als te summier bestempelen. Dit blijkt ook uit de grote behoefte aan scholing op oogheelkundig gebied bij aanstaande huisartsen.

\subsubsection{Naseholing voor huisartsen met betrekking tot de oogheelkunde}

\subsubsection{Georganiseerde nascholing}

Georganiseerde nascholung biedt de huisarts de mogelijkheid kennis en vaardigheden op diverse gebieden op te doen. De aard van de geboden onderwerpen weerspiegelt niet zozeer de lacunes in kennis en kunde bij de huisarts, alswel de belangstelling voor bepaalde onderwerpen (Bouhuys 1981).

Het postacademisch onderwijs in de geneeskunde wordt in Nederland verzorgd door diverse plaatselijke, regionale en landelijke organisaties. De Boerhaave Commissie te Leiden, het PAOG te Nijmegen en de Dr G.J. van Hoytema Stichting te Enschede behoren tot de grootste.

In Leiden werd in de periode van 1981 tot 1986 eén eendaagse cursus oogheelkunde voor huisartsen gegeven. Hetzelfde geldt voor Enschede. Het PAOG-H te Nijmegen organiseerde in die zes jaar een tweedaagse cursus oogheelkunde voor huisartsen en een eendaagse cursus vaardigheidstraining oogheelkunde voor huisartsen, welke vijf maal werd herhaald.

In de winter van 1982-83 werd door Professor Lamers te Maastricht voor (aanstaande) huisartsen een cursus oogheelkunde van 6 mall drie uur gegeven. Gedurende zeven wintermaanden werd een maal per maand een drie-urige cursus gegeven. Geoefend werd met spleetlamp, applanatie-tonometer en indirecte fundoscoop.

\subsubsection{Vakliteratuur}

Ook door het bestuderen van vakliteratuur kan de huisarts zich nascholen. Nagegaan werd hoe groot het aantal artikelen betreffende oogheelkunde was in de belangrijkste voor de huisarts toegankelijke tijdschriften.

Tot deze categorie zijn die medische tijdschriften gerekend die niet tot de specialistische literatuur behoren en in de Nederlandse taal zijn geschreven.

Tabel 2.3.3.2.- 1 geeft een overzicht van de bestudeerde tijdschriften en het aantal artikelen per tijdschrift van 1970 tot medio 1986 dat betrekking had op een oogheelkundig onderwerp. 


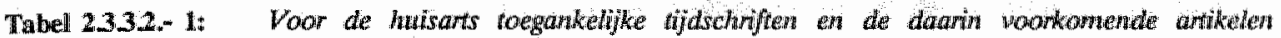
betreffende de oogheelkunde in de aangegeven periode.

Tijdschrift

Huisarts en Wetenschap

Patient Care (Ned ed.)

Practitioner (Ned ed.)

Vademecum ${ }^{2}$

Geneesmiddelenbulletin.

N.T.W.G ${ }^{3}$

Periode

$\begin{array}{lr}71-86 & 4 \\ 74-86 & 6 \\ 84-86^{1} & 8 \\ 83-86^{11} & 6 \\ 71-86 & 6 \\ 71-86 & 47\end{array}$

hiet voor deze periode werschenen

Vademecum Permanente Nascholing Huisartsen

Wederlands Tijdschrift voor Geneeskunde. N.B. alleen die artikelen zijn geselecteerd die mogelijk van belang zouden kunnen zijn voor de huisarts.

Uit de tabel blijkt, dat de oogheelkunde in 15 jaar in de genoemde tijdschriften in feite nauwelijks an de orde is geweest. Alleen het Nederlands Tijdschrift voor Geneeskunde heeft een respectabel aanbod.

Wat opvalt in een groot aantal voor de huisarts geschreven boeken c.q. artikelen is de discrepantie tussen de beschrijving van oogheelkundige bevindingen en de onderzoeksmethoden die worden geadviseerd om deze op het spoor te komen. Men adviseert bijvoorbeeld het gebruik van de directe fundoscoop en laat afbeeldingen van de oogfundus zien zoals waargenomen met een indirecte funduscoop (Schweitzer 1986). Het benadrukte belang van het aantonen van oogdruk-verschillen wordt weersproken door het advies de oogdruk te meten met de Glaucotest (o.a.: Collins e.a. 1977). Een pleidooi voor vroeg-diagnostiek van ernstige aandoeningen bij het rode oog wordt geillustreerd met afbeeldingen van een ernstig beschadigd oog, b.v. ten gevolge van een iridocyclitis of een chronische herpesinfectie (o.a.: van Bijsterveld, Ekdom 1987).

\subsection{Wetenschappelijk onderzoek met betrekking tot oogheelkundige problemen in de huisartspraktijk}

Het aantal onderzoeken dat betrekking heeft op oogheelkundige problemen in de huisartspraktijk is uiterst beperkt. Screening van de Nederlandse tijdschriften en bestudering van de met behulp van de literatuursearch verzamelde buitenlandse artikelen leverde in totaal zeven ter zake doende artikelen op. Slechts twee daarvan haddlen betrekking op onderzoek dat daadwerkelijk binnen de huisartspraktijksetting plaatswond. Twee proefschriften geschreven door een huisarts, handelen over een oogheelkundig onderwerp.

In totaal zijn vier studies gewijd aan de opsporing van glaucoom.

Van Rens (1976), huisarts, onderzocht alle inwoners van Oirschot boven 65 jaar op het bestaan van een te hoge oogdruk. Het onderzoek vond niet plaats in de praktijk van de verschillende huisartsen, maar werd in de vorm wan een bevolkingsonderzoek uitgevoerd. Er werd zowel met de Schiötz-tonometer als met de Glaucotest gemeten. $10 \%$ van de onderzochten bleken een te hoge oogdruk (hoger dan $22 \mathrm{~mm} \mathrm{Hg}$ ) te hebben die voorheen niet bekend was. 
Tielens e.a. (1985) onderzochten het feitelijk medisch-diagnostisch handelen van 57 huisartsen aan de hand van observatie-gegevens van 520 contacten. $Z$ ij onderscheidden drie grote categorieên:

A: de huisarts neemt alleen de anamnese op en doet nauwelijks een lichamelijk onderzoek.

B: de huisarts doet ook een witvoerig lichamelijk onderzoek.

C: anamnese en lichamelijk onderzoek zijn zeer gericht.

Oogklachten blijken wolgens dit onderzoek een typisch voorbeeld van de medischdiagnostische benadering door de huisarts volgens categorie A.

Van de Beek en Schiffelers (1982), onderzochten via een aselecte steekproef van 100 Nederlandse huisartsen in hoeverre de Nederlandse huisarts de funduscopie beoefent. 55 Artsen beantwoordden de enquête. 51 bezaten een directe en 4 bezaten een indirecte oogspiegel. Acht beoefenden dagelijks de funduscopie,", de rest wekelijks tot hooguit sporadisch. Tien zeiden het direct spiegelen goed te beheersen; één zei het indirect spiegelen goed te beheersen.

Van de $\operatorname{Kar}$ (1988) onderzocht de bruikbaarheid van fundusfotografie als diagnostisch hulpmiddel bij vroegtijdige opsporing van diabetische retinopathie ten behoeve van de huisarts. Vier huisartsen en een internist gaven op grond van de afzonderlijke foto's hun oordeel over het al dan niet aanwezig zijn van diabetische retinopathie. De beoordelingen werden vergeleken met de beoordelingen van twee oogartsen. Het gebruik van de fotomethode door niet-oogartsen leidde tot een hoge sensitiviteit.

De bellangrijkste morbiditeitsregistraties uit de huisartspraktijk worden uitvoerig besproken in hoofdstuk 7 , te weten: het monitoringproject van Lamberts (Lamberts 1984), de Continue Morbiditeits Registraties van Nijmegen (NUHI 1985) en de registraties van Hodgkin (1978) en Oliemans (1969). De categorie oogheelkunde binnen al deze registraties is zeer globaal ingedeeld. Een categorie betreffende fundoscopische bevindingen ontbreekt geheel.

Een aantal artikelen had betrekking op onderzoek uitgevoerd in en rond huisartspraktijken in Engeland en Amerika. De situatie aldaar is in meerdere opzichten niet geheel vergelijkbaar met de Nederlandse. De opleiding van de huisarts verschilt en in zowel Engeland als Amerika is de opticien veel actiever op het gebied van oogheelkundige diagnostiek. Deze meet bijvoorbeeld ook de oogdruk.

In de Verenigde Staten ondervroeg Tucker (1981), zelf huisarts, 352 opleidingspraktijken voor huisartsen ("family practice residencies") met behulp van een vragenlijst naar hun activiteiten ter opsporing van glaucoom (respons 66.2\%). 67.8\% van de respondenten gaf aan hierop regelmatig te onderzoeken. De indicaties en onderzoeksmethoden verschilden echter aanzienlijk.

Howie en Taylor (1982), twee Engelse huisartsen, onderzochten op welke wijze patienten met verhoogde oogdruk bij de oogarts terecht kwamen. Zij concludeerden, dat de meeste patienten die met mogelijk verhoogde oogdruk door huisartsen werden verwezen in feite waren opgespoord door de opticien. De auteurs bepleitten de mogelijkheid voor opticiens rechtstreeks te verwijzen naar de oogarts om doctorsdelay te voorkomen.

Ook Steinmann, (1982), huisarts, onderzocht in Engeland via welke kanalen potentiële glaucoompatiënten uiteindelijk bij de oogarts terechtkwamen. 205 glaucoma simplex patienten bleken te zijn verwezen door de opticien waarvan $88 \%$ onder de 
correcte diagnose. Via de huisarts werden 65 glaucoma simplex patiënten verwezen waarvan $25 \%$ onder de correcte diagnose.

Bij deze twee laatstgenoemde artikelen van Engelse artsen moet worden aangetekend dat Engelse oogartsen geen brillen voorschrijven. Alle refractieproblematiek gaat rechtstreeks naar de opticien, die ook de oogdruk meet.

Price en Philips (1976), huisarts respectievelijk oogarts beschrijven het resultaat van het inzetten van een huisarts een ochtend in de week op de Eerste Hulp van een universitaire oogkliniek (Edinburgh). Deze huisarts had geen specifieke oogheelkundige training voordat het experiment begon. Zij volgde tien ochtenden de colleges oogheelkunde aan medische studenten, kreeg tien ochtenden les in oogheelkundige spoedgevallen, woonde vijf spreekuren van een oogarts bij, maakte vier zaalvisites mee en deed vier ochtenden samen met een ervaren oogarts het eerste hulp-werk op de oogheelkundige kliniek. Daarna kreeg zij een ochtend in de week de verantwoording voor het oogheelkundige eerste hulp werk, met de mogelijkheid terug te vallen op een ervaren oogarts. Haar via steekproeven gecontroleerde arbeid bleek kwalitatief gelijk aan dat van de oogartsen.

Bain (1977), huisarts, observeerde 20 huisartsen tijdens hun zuigelingen- en kleuterburowerk en registreerde de door de huisarts uitgevoerde onderzoekingen. Slechts een kwart van de kinderen werd op scheelzien onderzocht. Het bepalen van de gezichtsscherpte varieerde per leeftijdscategorie. Belangrijk was de constatering, dat de huisartsen de waarde van de uitgevoerde testen betwijfelden. Zij varen in hun oordeel meer op het kennen van het gezin en de moeder en haar oordeel over het kind dan op het resultaat van hun onderzoekingen. Bain vindt dit in geval van tests betreffende het horen en het zien niet terecht.

Deze summiere opsomming laat de conclusie toe, dat de oogheelkunde in de huisartspraktijk een wetenschappelijke onderbouwing nog grotendeels ontbeert en gebaat zou zijn bij verder onderzoek.

\subsection{Samenvatting en conclusies}

Over de wijze, waarop huisartsen omgaan met oogheelkundige problemen in de Nederlandse huisartspraktijk is weinig bekend.

De in het Basistakenpakket en in het rapport Kenmerken II gegeven richtlijnen geven globaal aan, wat van de huisarts aan kemnis en vaardigheden op het gebied van de oogheelkunde mag worden verwacht. Deze richtlijnen verdienen echter nadere uitwerking, om als leidraad voor systematische nascholing te kunnen dienen.

Uit het onderzoek van Tan komt een lijstje van noodzakelijk geachte kennis en vaardigheden naar voren dat aanzienlijk beperkter is, dan hetgeen in bovengenoemde rapporten wordt vermeld.

Het aantal tijdschriftartikelen, gericht op de huisarts waarin de oogheelkunde aan de orde komt, is niet groot. In de meeste daarvan wordt de noodzaak van vroegtijdig onderkennen van diverse oogaandoeningen benadrukt. Bij de didactische kwaliteit van de gedane aanbevelingen zijn kanttekeningen te plaatsen.

Uit de verwijscijfers naar de oogarts blijkt, dat oogproblemen veel worden verwezen.

Het onderwijs in de oogheelkunde aan de basisarts betreft slechts een oriëntatie in dit vak. In de beroepsopleiding tot huisarts en de nascholing is onderwijs in de oogheelkunde een randgebeuren. 
Onderzoek naar het feitelijk handelen van huisartsen betreffende oogheelkunde in de praktijk en de opbrengst daarvan is uiterst schaars.

Ook de inventarisatie van het morbiditeitsaanbod laat te wensen over. De gehanteerde indelingen zijn grofmazig of lacunair (ophthalmoscopische gegevens, bijvoorbeeld, zijn nauwelijks te vinden) en scherp omschreven criteria voor de diverse diagnosecategorieen ontbreken of verschillen per registratie.

Men zou mogen stellen, dat huisartsen hun taak op het gebied van de oogheelkunde nog niet voldoende duidelijk en volledig hebben omschreven, om de individuele huisarts een houvast te bieden voor bijscholing en intensivering van aandacht voor dit onderdeel van het wak. Een probleem daarbij is, dat onderzoeksgegevens op grond waarvan men een oordeel zou kunnen vellen over de juistheid van de gegeven en te geven richtlijnen, niet voorhanden zijn.

Een aanzet om te komen tot voorstellen voor een haalbare en effectieve aanpak wan oogheelkundige problemen door de huisarts zal moeten beginnen bij een adekwate inventarisatie van het aanbod.

Vervolgens vraagt de gehanteerde werkwijze en de opbrengst daarbij de aandacht. Is die opbrengst zodanig, dat gesproken kan worden van voorkomen van vermijdbaar verlies van gezichtsvermogen en van langdurig bestaande oogklachten? Levert die opbrengst de huisarts informatie op ten aanzien van de algemene gezondheidstoestand van de patiënt? Welke onderzoeksmethoden leiden tot het diagnostiseren van aandoeningen en welke argumenten zijn te geven voor het propageren van deze methoden voor huisartsen in het algemeen? Een en ander is uitgewerkt in de onderzoeksvragen die in het volgende hoofdstuk worden besproken. 


\section{Hoofdstuk 3}

\section{AANLEIDING TOT HET ONDERZOEK EN DE ONDERZOEKSVRAGEN}

De gegevens uit de vorige hoofdstukken roepen vragen op ten aanzien van het handelen van huisartsen bij oogheelkundige problemen. De constatering, dat in elk gevall de eigen werkwijze niet adekwaat was en de overtuiging, dat dit mede veroorzaakt werd door de wijze waarop huisartsen de oogheelkunde kregen geleerd, vormde de aanleiding voor een intensieve "herscholing" op het gebied van de oogheelkunde. Doel was daarbij in de eerste plaats te achterhalen, waar de grens lag tussen de huisartsgeneeskundige en de specialistische oogheelkunde en wat binnen het domein van de huisartsgeneeskundige oogheelkunde tot het pakket van kennis en vaardigheden zou moeten behoren. Leidraad daarbij was het oogheelkundig probleemaanbod in de eigen praktijk, de "inpasbaarheid" van oogheelkundig onderzoek in de totale praktijkvoering en de "opbrengst" in de zin van adekwaat en efficient benaderen van oogheelkundige problemen. Vanaf 1977 werd oogheelkundige apparatuur aangeschaft en aanvullende scholing gevolgd. Al doende kristalliseerde zich een idee uit betreffende huisartsgeneeskundige oogheelkunde. Een plan tot systematische inventarisatie wan het oogheelkundig probleemaanbod en van de opbrengst van de eigen benadering daarvan wormden de aanleiding tot het onderhavige onderzoek.Besloten werd speciaal aandacht te besteden aan preventie van verminderd gezichtsvermogen.

Een en ander resulteerde in de volgende onderzoeksvragen:

A. Met welk probleemaanbod - in termen van diagnosen op het gebied van de oogheelkunde - werd de huisarts in deze praktijk geconfronteerd?

B. In hoeverre betrof dit diagnosen, van belang in het kader van preventie van verminderd gezichtsvermogen?

C. Met welke klachten en/of problemen presenteerden de mensen zich bij wie de bovengenoemde diagnosen werden gesteld? 
D. Welke oogheelkundige onderzoeksmethoden werden daarbij gebruikt?

E. In welke mate werden de gepresenteerde oogheelkundige problemen zelfstandig afgehandeld dan wel verwezen naar oogarts of opticien?

F. In hoeverre werd de juistheid van de onder $A$ bedoelde diagnosen door de followup bevestigd? 


\section{Hoofdstuk 4}

\section{BESCHRIJVING VAN DE PRAKTIJK}

De huisartspraktijk waar het onderzoek plaatsvond is gevestigd te Brunssum. Brunssum telt ongeveer 27.000 inwoners. Aan het einde van de vorige eeuw woonden er 3000 mensen. De aanblik van Brunssum is aan het begin van deze eeuw sterk veranderd door de opkomst van de mijnindustrie. De bevolkingsaanwas werd vooral bepaald door de toestroom van arbeiders uit gebieden elders in Nederland met een hoge werkloosheid. Onder de alleroudste inwoners zijn nog mijnwerkers uit de beginjaren, die, terugdenkend aan die tijd geëmotioneerd praten over hoe ze hun vertrouwde huiselijke omgeving moesten verlaten en "emigreerden" naar Zuid-Limburg waar goed geld was te verdienen.

Ten tijde van het onderzoek, peildatum 1-1-1983, telde de duo-praktijk (Baggen \& Vaessen) ongeveer 4500 patiënten, waarvan 3300 fondspatienten en 1200 particulieren. De opbouw in aantallen verdeeld naar leeftijd en geslacht wordt weergegeven in tabel 4.- 1. Daarbij wordt tevens een vergelijking gemaakt met de opbouw van de Nederlandse bevolking.

Tabel 4.- 1: Praktijkopbouw en opbouw van de Nederlandse bevolking noar leeftijd en geslacht (in percentages).

\begin{tabular}{|c|c|c|c|c|}
\hline \multirow[b]{2}{*}{ Leefitijd } & \multicolumn{2}{|c|}{ Praktijk } & \multicolumn{2}{|c|}{ Bevolking } \\
\hline & Mannen & Vrouwen & Mamnen & Vrouwen \\
\hline $0=4$ & 2.7 & 2.5 & 3.2 & 3.0 \\
\hline $5-14$ & 7.7 & 6.5 & 7.3 & 7.0 \\
\hline $15-24$ & 8.4 & 8.8 & 8.9 & 8.5 \\
\hline $25-44$ & 1148 & 15.5 & 15.6 & 14.8 \\
\hline $44-64$ & 11.8 & 12.5 & 9.9 & 10.2 \\
\hline 65 en ouder & 4.0 & 4.8 & 4.7 & 6.9 \\
\hline
\end{tabular}


Uit de tabel blijkt dat de opbouw van de praktijk weinig afwijkt van die van de Nederlandse bevolking. Alleen de vrouwen van 65 jaar en ouder lijken in de praktijk jets ondervertegenwoordigd. 


\section{Hoofdstuk 5}

\section{METHODE}

Het onderhavige onderzoek moet worden beschouwd als een descriptief onderzoek betreffende het oogheelkundig probleemaanbod in een tweemanspraktijk. De oogheelkundige problemen werden alle gezien en geregistreerd door één huisarts (Baggen), tevens onderzoeker.

\subsection{Organisatie}

In de praktijk (4500 patiënten) werken twee huisartsen, soms éen, soms twee huisartsen in opleiding en twee doktersassistenten. Tijdens de periode van onderzoek gold de afspraak, dat alle oogproblematiek naar de onderzoeker zou worden verwezen. Regelmatig werd nagegaan of deze afspraak ook werd nagekomen.

\subsection{De registratieperiode}

Gedurende ruim 21 maanden werden alle door de onderzoeker geziene oogheelkundige problemen geregistreerd. Indien hiervan de dagen wegens afwezigheid worden afgetrokken blijven ongeveer 18 maanden over. De totale registratieperiode betrof dus anderhalf jaar.

\subsection{De wijze van registreren}

Bij de registratie werd gebruik gemaakt van een standaardformulier. Hiermee werden in totaal 910 consulten geregistreerd. De onderzoeker registreerde de consulten zelf. Uit het feit, dat gebruik werd gemaakt van een standaardformulier moet niet worden opgemaakt, dat ten behoeve van het onderzoek steeds een standaard-c.q. volledig oogonderzoek werd uitgevoerd. Het oogonderzoek werd verricht op geleide van de gestelde hypothese(n), zoals in de huisartspraktijk gebruikelijk is.

\subsection{Rubricering}

$\mathrm{Na}$ de registratieperiode werd een rubriekenlijst samengesteld aan de hand waarvan het computerformulier door de onderzoeker werd ingevuld. Computerformulier en rubriekenlijst zijn weergegeven in respectievelijk bijlage III en IV.

Een aantal rubrieken vereisen enige toelichting: 
Soon van eerste consult

Bij het oplossen van problemen speelt vo6rkemnis van dat probleem een grote rol. Met "soont wan het eerste consult" wordt verwezen nat de aard van die voorkennis in relatie tot het betreffende oogprobleem. Er werden drie subcategorie.en onderscheiden:

Onder "nieuwe" problematiek (1) werd verstaan, een zodanige presentatie van oogklachten door de patiënt, dat de arts bij de aanvang van het consult veronderstelde, met een nieuw oogprobleem te maken te hebben. Dit laat onverlet, dat tijdens het consult kon blijken, dat het in feite om een reeds bekend probleem ging.

Onder "oude" problematiek (2) werd verstaan, oog-problematiek die bij de aanvang wan het consult door de arts werd herkend als bekend. Dus een probleem, dat vó6r de registratieperiode hetzij reeds gezien was door de (huis)arts betzij door de oogarts. Dit laat onverlet, dat gaande het consult nieuwe afwijkingen aan het licht konden komen.

Een derde categorie (3) betrof niet-oogheelkundige aandoeningen, waarbij risico voor oog-complicaties aanwezig was, zoals hypertensie en diabetes, maar waarbij de patiënt geen klachten met betrekking tot het oog naar voren bracht. Oogonderzoek bij deze categorie van aandoeningen vond uitsluitend plaats op initiatief van de arts.

\section{Kenmerken van de patiënt}

Een drietal soorten van aandoeningen die bekend staan om het bijbehorend risico op oogcomplicaties, werd geregistreerd onder het hoofd: kenmerk van de patient.

"Hypertensie" werd als kenmerk van een patiënt aangeduid, indien die patiënt tijdens het onderzoek of in het verleden antihypertensiva gebruikte of had gebruikt.

"Diabetes" werd als kenmerk van de patiënt geregistreerd, indien de patiënt bij de (huis)arts dan wel bij de internist werd gecontroleerd voor zijn/haar diabetes.

"Cardiovasculaire ziekte" werd als kenmerk geregistreerd bij personen met ziekten van de kransslagaderen, claudicatio intermittens, hartdecompensatie en herseninfarcten. Rheumatische en congenitale klepgebreken werden niet geregistreerd als cardiovasculaire ziekten.

\section{Initiatief tot oogonderzoek}

In deze rubriek werd aangegeven op wiens initiatief het oogonderzoek werd verricht. Dit kan zijn op verzoek van de patiënt of diens begeleider (b.v. ouders), van de (huis)arts (= de onderzoeker) of van "anderen". Onder "anderen" wordt verstaan: andere artsen, b.v. artsen van het consultatieburo.

\section{Reden van oogheelkundig onderzok}

De geregistreerde klacht was de klacht, waarmede de patiënt zich presenteerde. Deze werd zoveel mogelijk letterlijk geregistreerd. De klachten werden achteraf onderverdeeld in "specifieke oogklachten" en (geen oogklachten, maar) "vage, algemene klachten" (b.v. misselijkheid, hoofdpijn). Bij deze laatste categorie klachten vormde de verdere anamnese de aanleiding, om tot onderzoek van de ogen te besluiten.

De specifieke oogklachten werden onderverdeeld in: klachten over het zien, pijn aan het oog, klachten over standsafwijkingen, klachten over het gezichtsveld, klachten over de adnexen en overige oogklachten. Voor een uitvoeriger beschrijving wordt verwezen naar paragraaf 8.1. 
Omdat ook oogonderzoek werd verricht op initiatief van de arts bij personen die geen oogklachten hadden maar een afwijking met risico woor het oog, zoals diabetes, werd nog een derde rubriek toegevoegd, namelijk "geen klachten; wel afwijkingen met risico voor oogcomplicaties".

Meestal werd slechts én reden van oogheelkundig onderzoek op het computerformulier geregistreerd. Slechts sporadisch werd zowel een specifieke oogklacht geregistreerd, als ook "geen klachten, wel afwijkingen" bijv. bij diabetes.

\section{Resultaat visusonderzoek}

Bedoeld is de visus veraf. Indien de persoon brildragend was is de visus met correctie opgegeven. Bij waarden beneden 0.4 werd "minder dan $0.4^{\text {" }}$ geregistreerd. Volgens de WHO-criteria is een oog met een visus minder dan 0.4 maar meer dan $2 / 60$ slechtziend. Een oog met een visus van minder dan $2 / 60$ wordt blind genoemd. Beneden de waarde 0.4 werd in dit onderzoek geen verder onderscheid gemaakt, omdat dit voor het beleid niet relevant werd geacht. Personen met een visus van minder dan 0.4 van beide ogen samen werden benoemd als "slechtziend/blind"

\section{Soort bevinding}

Geconstateerde afwijkingen werden als volgt ingedeeld:

1: deze afwijking wordt nu voor het eerst geconstateerd; de gevonden afwijking is zeer waarschijnlijk de verklaring voor de klacht van de patiënt.

2: deze afwijking wordt nu voor het eerst geconstateerd; de gevonden afwijking verklaart mogelijk de klacht van de patiënt.

3: deze afwijking wordt nu voor het eerst geconstateerd; het is een zuivere toevalsbevinding, of is ontdekt bij surveillerend onderzoek.

4: deze afwijking werd reeds eerder door de arts/onderzoeker ontdekt.

5: deze afwijking werd reeds eerder door de oogarts ontdekt.

\section{Diagnose/bevinding}

De vermelde diagnosen zijn de diagnosen zoals die gesteld werden door de onderzoekend (huis)arts en waarmee de patiënt bij wijze van spreken "het praktijkpand verliet".

Sommige van die diagnosen zijn voorzien van het adjectief "mogelijk", "misschien" of "waarschijnlijk". Daarmee werd aangegeven dat ofwel meer exacte diagnostiek van weinig klinisch belang was (b.v. conjunctivitis), of dat meer exacte diagnostiek alleen in de tweede lijn, met andere hulpmiddelen, kon plaatsvinden (b.v. glaucoom).

Enkele diagnosen c.q. bevindingen verdienen nog enige toelichting:

- presbyopie

Presbyopie is eigenlijk geen refractieafwijking, maar een probleem ten gevolge van accomodatiezwakte. Omdat deze accomodatiezwakte echter wordt gecorrigeerd met een sferische correctie voor het dichtbij zien, werd de presbyopie gerangschikt onder de refractieafwijkingen.

- visusafwijking ten gevolge van een refractieafwijking

Deze globale omschrijving werd, in plaats van bijvoorbeeld myopie of hypermetropie, gehanteerd, wanneer er een refractieafwijking bestond waarvan de aard niet duidelijk was of wanneer er combinaties van refractieafwijkingen in het spel waren. Bijvoorbeeld presbyopie met een slecht gecorrigeerde myopie. 


\section{- cataract}

Bij cataract gaat het om troebelingen in de ooglens. Zeer veel personen hebben trowelingen in de onglens, zonder daarvan hinder te ondervinden. Zij hebben een normale visus. In dit onderzoek is in dergelijke gevallen niet van cataract gesproken. Gesproken werd van "in geringe mate cataract" bij troebelingen in de ooglens en een visus tussen 0.8 en 1.0, warbij andere oorzaken van de visusvermindering waren uitgesloten. Troebelingen in de ooglens werden als "(duidelijk) cataract" geregistreerd, indien de patient daarbij een visus had van minder dan 0.8 .

\section{Hoofddiagnose van dit probleem}

Onder de kop: hoofddiagnose, werd de voornaamste oogheelkundige bevinding van het betreffende consult geregistreerd. Deze hoofddiagnose kon in principe los staan van het door de patient aangeboden probleem. Bijvoorbeeld, bij iemand met klachten van slecht zien bij het lezen, waarbuj naast een presbyopie een primair chronisch glaucoom werd geconstateerd, werd dit laatste als hoofddiagnose geregistreerd.

\section{Follow up en evaluatie}

Ruim drie jaar na het laatst geregistreerde consult werden alle geregistreerde oogproblemen opnieuw doorgenomen. Nagegaan werd, of achteraf gezien, de gestelde diagnose juist was geweest. Bij de niet verwezen patiënten werd op de patiëntenkaart gekeken of zich achteraf ontwikkelingen hadden voorgedaan die konden wijzen op een foutief gestelde diagnose. Bij de naar de oogarts verwezen patiënten werd de verwijsindicatie vergeleken met hetgeen de oogarts naar wie werd verwezen, terugrapporteerde.

\subsection{Negatieve diagnostiek}

De zo genoemde "negatieve diagnostiek" neemt in dit onderzoek een bijzondere plaats in en vereist enige toelichting.

Een konsekwente voortgang van het diagnostisch proces veronderstelt vaak de noodzaak bepaalde ziekten uit te sluiten. Vaak gaat het daarbij om ernstiger afwijkingen. Men zou zelfs mogen zeggen, dat pas tot een onschuldige aandoening besloten mag worden, nadàt men de mogelijkheden van een ermstige ziekte heeft overwogen en uitgesloten. Het concluderen tot de afwezigheid van bepaalde ernstige aandoeningen stelt vaak hogere eisen aan het onderzoek (en de onderzoeker) dan het aantonen van aperte pathologie.

Voor het beleid bij oogheelkundige problemen is de negatieve diagnostiek van eminent belang. Verwijzing naar de opticien bij een wermeende refractieafwijking is pas dan verantwoord, indien en aantal potentieel gevaarlijke aandoeningen, zoals glaucoom en funduspathologie, is uitgesloten.

Ondlat in dit onderzoek het uitsluiten van bepaalde pathologie vaak een essentieel onderdeel van de diagnostiek uitmakte, zijn de negatieve diagnosen in de registratie opgenomen. In dergelijke gevallen is gesproken van "geen glaucoom" "geen diabetische retinopathie enz".

\subsection{Incidenties}

Daar waar in de tekst sprake is van incidenties wordt bedoeld het aantal nieuwe gevallen, c.q. nieuw ontdekte gevallen, zoals geregistreerd door de (huis)arts/onderzoeker per 1000 geregistreerde personen per jaar. 


\section{Hoofdstuk 6}

\section{AARD EN AANTAL DER CONSULTEN}

\subsection{Inleiding}

Doel van dit hoofdstuk is inzicht te geven in de omvang en diversiteit van het oogheelkundig probleemaanbod dat gedurende de registratrieperiode aan de onderzoeker werd gepresenteerd.

Een overzicht wordt gegeven van de aard en aantallen van de consulten die besteed zijn aan oogheelkundige en daaraan gerelateerde problemen.

Tevens wordt de oogheelkundig onderzochte populatie omschreven in termen van leeftijds- en geslachts-verdeling alsmede verzekeringsvorm.

Tot slot komt het aantal zelfstandig afgehandelde problemen in relatie tot het aantal verwijzingen aan de orde.

\subsection{Het registreren van de oogheelkundige problemen}

De periode gedurende welke werd geregistreerd bedroeg anderhalf jaar. Gedu-rende deze periode werd het oogheelkundig probleemaanbod geregistreerd, dat bij de (huis)arts/onderzoeker op het spreekuur werd gepresenteerd.

De afspraak gold daarbij, dat deze alle in de praktijk gepresenteerde problemen zou zien. Verzoeken om een verwijskaart voor de oogarts zonder diens tussenkomst werden niet ingewilligd. De assistenten hadden tot taak erop toe te zien, dat oogheelkundige problemen niet bij de associé terecht kwamen, terwijl de associé de alsnog aan hem gepresenteerde oogheelkundige problemen in tweede instantie naar de onderzoeker verwees. Later werd nagegaan, of deze afspraak ook zorgvuldig was nagekomen. Daarbij bleek geen noemenswaardig verschil te bestaan in geregistreerd aanbod tussen perioden van aan- en afwezigheid van de associé. De met de associé gemaakte afspraak gold ook voor de assistenten in opleiding tot huisarts. De consulten van de oogarts die tot stand kwamen zonder tussenkomst van de huisarts, ten behoeve van degenen die zich rechtstreeks tot de Eerste Hulp of de oogarts wendden, werden niet in de registratie opgenomen. Daar zowel bij patienten als bij het ziekenhuis al jaren bekend was, dat de oogheelkunde tot de speciale aandachtsgebieden van de 
onderzoeker behoorde, mag men aannemen, dat het aantal van dergelijke consulten gering was.

Men kan er derhalve van uitgaan, dat het in dit onderzoek gepresenteerde aanbod nagenoeg het gehele aanbod van in deze praktijk gepresenteerde oogheelkundige problemen betreft.

\subsection{De oogheelkundige consulten nader bekeken}

\subsubsection{Aantal oogheelkundige consulten, patiënten en problemen}

Geregistreerd zijn zowel het aantal consulten als het aantal patiënten aan wie deze consulten werden besteed als het aantal oogheelkundige problemen.

In tabel 6.2.1.- 1 zijn de aantallen oogheelkundige consulten, patiënten en problemen weergegeven, die in anderhalf jaar tijd werden geregistreerd, evenals de daaruit berekende jaarcijfers voor een norm-praktijk (2250 patiënten)

Tabel 6.2.1.- 1: Geregistreerd auntal ogghelkundige consulten, patiënten en problemess in een periode van anderhalf jaar in het eigen onderzoek en daanuit afgeleide jaarciffers woor een norn-praktijk (2250 paitenten).

Eigen onderzock Normpraktijk

anderhalf jaar op jaarbasis

Aantal consullen

910

303

Aantal personen

Aantal afzonderlijke problemen

Indien deze cijfers representatief zouden zijn voor de Nederlandse huisarts, dan zou dat betekenen, dat:

- de huisarts gemiddeld eenmaal per dag zou worden geconfronteerd met een oogheelkundig probleem.

- jaarlijks ongeveer $10 \%$ van de praktijkpopulatie oogheelkundig zou worden onderzocht.

Nagegaan is, in hoeverre oogheelkundige problemen steeds door dezelfde dan wel door verschillende personen werden gepresenteerd, hetgeen wordt weergegeven in tabel 6.2.1.-2.

Tabel 6.2.1.- 2: Aantal oogheekundige problemen per persoon

$\begin{array}{cc}\text { Aant:al } & \text { Aantal } \\ \text { oogproblemen } & \text { personen }\end{array}$

$\begin{array}{rr}1 & 629 \\ 2 & 51 \\ 3 & 3 \\ 4 & 2\end{array}$

Uit tabel 6.2.1.- 2 blijkt dat slechts vijf personen meer dan twee afzonderlijke oogheelkundige problemen aanboden in de gehele registratieperiode. 
Een indicatie voor de "bewerkelijkheid" van oogheelkundige problemen wordt gevormd door het aantal consulten per probleem.

Een overzicht van het benodigd aantal consulten per oogprobleem wordt weergegeven in tabel 6.2.1.- 3. Hierbij moet worden opgemerkt, dat geen onderscheid is gemaakt tussen herhaalconsulten op initiatief van de arts en herhaalconsulten op initiatief van de patiënt.

Tabel 6.2.1.- 3: Aantal geregistreerde consulten per oogprobleem $(N=748)$.

\begin{tabular}{cr}
$\begin{array}{c}\text { Aantal } \\
\text { oogproblemen } \\
\text { in percentages }\end{array}$ & $\begin{array}{r}\text { Aantal } \\
\text { consulten } \\
\text { absolute aan }\end{array}$ \\
\hline 84.4 & 1 \\
11.2 & 2 \\
2.1 & 3 \\
1.1 & 4 \\
0.8 & 5 \\
0.3 & 6 \\
0.1 & 7
\end{tabular}

Opvallend is het hoge percentage oogproblemen dat in een eenmalig consult werd afgehandeld. Daarbij moet worden aangetekend, dat in $9.7 \%$ van de gevallen na een eenmalig consult verwijzing maar de oogarts plaatsvond.

Uit de tabel blijkt, dat in nog geen $5 \%$ van de gevallen drie of meer consulten aan één oogprobleem werden besteed en in slechts $2.3 \%$ van de gevallen vier consulten of meer.

Nagegaan is, welk soort van problemen zo intensief werd vervolgd. Tabel 6.2.1.- 4 geeft een overzicht van de hoofddiagnosen, waaraan vier of meer consulten werden besteed. Ook is het aantal malen weergegeven, dat de genoemde aandoeningen in de totale registratie voorkwamen.

Opvallend is, dat de lijst zowel onschuldige aandoeningen zoals virale conjunctivitis, als gevaarlijke aandoeningen zoals keratitis dendritica en ernstige fundus-pathologie bevat. Ook gaat het zeker niet hoofdzakelijk om aandoeningen, die men het label "chronisch" zou kunnen geven. Een noemer waaronder de opgesomde aandoeningen zouden kunnen worden geschaard, ligt niet direkt voor de hand. Uit de tabel blijkt ook, dat het aantal malen, dat meerdere consulten aan een aandoening werden besteed, slechts een fractie is van het aantal malen, dat de betreffende aandoening voorkwam. Men kan dus evenmin concluderen, dat bepaalde aandoeningen in dit onderzoek als zodanig "bewerkelijk" waren. Een uitzondering hierop vormt de acute uveïtis anterior. Hieraan werden in drie van de vier gevallen vier of meer consulten besteed. 


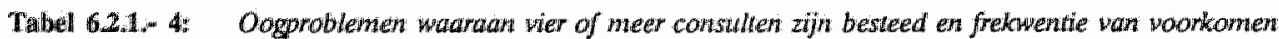
wan deze diagnosen in de gehele onderzoeksperiode $(N=17)$

\begin{tabular}{|c|c|c|}
\hline Hoofdriagnose & Aantal & $\begin{array}{l}\text { Frequentie } \\
\text { vain } \\
\text { voorkomen }\end{array}$ \\
\hline \multicolumn{3}{|l|}{ refractiea wijkingen } \\
\hline $\begin{array}{l}\text { wisusalwijking tgv. } \\
\text { Een refractieafwijking } \\
\text { oogleden }\end{array}$ & 2 & 191 \\
\hline blefaritis & 1. & 10 \\
\hline trichiausis & 1 & 5 \\
\hline \multicolumn{3}{|l|}{ congunculiwal } \\
\hline virale conjunctivitis & 1 & 86 \\
\hline keratilis punctata & 1 & 13 \\
\hline keratitis dendritica & 1 & 2 \\
\hline keratitis marginalis & 1 & 11. \\
\hline roestring in cornea & 2 & 10 \\
\hline \multicolumn{3}{|l|}{ uvea } \\
\hline $\begin{array}{l}\text { acute wrentis anterior } \\
\text { fundes }\end{array}$ & 3 & 4 \\
\hline $\begin{array}{l}\text { fundus hypertonicus met bloedingen } \\
\text { diabetische retinopathic }\end{array}$ & 1. & 9 \\
\hline met bloedingen en exudaten & 1 & 4 \\
\hline andere vaatpathologie in fundo & 2 & 4 \\
\hline
\end{tabular}

Totalal

Ter illustratie volgt hier de casuïstiek van de vier personen met een iritis/iridocyclitis.

1. Bij een man van 49 jaar werd een corpus alienum uit de comea van het linker oog verwijderd. De volgende dag was het oog heftig rood ontstoken en werden met de spleetlamp cellen in de voorste oogkamer gezien. De conclusie was: iritis ten gevolge van traumatische prikkeling van de voorste oogkamer. Er werden in totaal vijf consulten aan het ziektegeval besteed. De patient werd aanvankelijk behandeld met chloramphenicol- en atropine-oogdruppels. Later met Di-adreson- en atropineoogdruppels. De man werd niet verwezen naar de oogarts en genas zonder restverschijnselen in ongeveer 10 dagen.

2. Een vrouw van 33 jaar had pijnklachten aan het rechter oog na zich te hebben geprikt aan een tak van de kerstboom. Bij onderzoek werd een comea-erosie gezien. De volgende dag was het oog flink pijnlijk en de erosie nog niet gesloten. De derde dag werden met de spleetlamp cellen in de voorste oogkamer gezien. De conchusie was: iritis ten gevolge van traumatische prikkeling van de voorste oogkamer. Er werden in totaal vijf consulten aan het ziektegeval besteed. Patiënte werd behandeld met chloramphenicol- en atropine-oogdruppels. Zij werd niet verwezen naar de oogarts en genas zonder restverschijnselen. 
3. Een vrouw van 33 jaar, dezelfde vrouw van casus 2 , werd dit keer aan haar linker oog geraakt door een uitzwaaiende hand wan haar baby, die zil op haar amn droeg. Bij onderzoek werd een comea-erosie gezien en cellen in de voorste oogkamer. Behandeling en genezing werliepen conform de beschrijving in casus 2.

4. Een vrouw van 50 jaar klaagde over een pijnlijk linker oog. Bij onderzoek met de spleetlamp werden cellen en Tyndall-fenomeen in de woorste oogkamer gezien. De diagnose iridocyclitis werd gesteld. Zij bleek in het verleden meerdere malen een inidocyclitis te hebben doorgemaakt. Haar gedrag was bovendien psychotisch. Derhalve werd zij direct verwezen naar de eerste hulp ter attentie van de PAAZ en tevens van de oogarts. Een verband tussen beide problemen werd niet verondersteld.

\subsubsection{Het aanbod aan oogheelkundige problemen, gerelateerd aan leeftijd en geslacht} van de patiënt

Nagegaan is, hoe "het probleemaanbod" werd gekenmerkt naar leeftijd en geslacht. Daartoe zijn de problemen die werden aangeboden ingedeeld naar leeftijd en geslacht van degenen die het probleem inbrachten. Ondat het aanbod, ook in dit opzicht, sterk bepaald wordt door de samenstelling van de praktijkpopulatie, is tevens nagegaan, hoe het aanbod zich per leeftijds- en geslachts-categorie verhoudt tot het totaal aantal personen in de betreffende categorie in de praktijk. Tabel 6.2.2.- 1 geeft de uitkomst hiervan weer.

Tabel 6.2.2-1: Alanbod van oogheelkundige problemen, gerelateerd aan leeftijd en geslachi van de patient; absoliut en als percentage van het totaal aantal personen per leeftijds-en geslachis-groep binnen de praktijkpopulatie.

\begin{tabular}{|c|c|c|c|c|c|c|}
\hline \multirow[b]{2}{*}{ Leeftijd } & \multicolumn{2}{|c|}{ Mannen } & \multicolumn{2}{|c|}{ Vrouwen } & \multicolumn{2}{|c|}{ Totaal } \\
\hline & Absoluut & Procentueel & Absoluut & Procentueel & Absoluut & Procentueel \\
\hline $0-4$ & 12 & 10.1 & 5 & 4.6 & 17 & 7.5 \\
\hline $5-14$ & 34 & 9.9 & 41 & 14.3 & 75 & 11.9 \\
\hline $15-24$ & 32 & 8.6 & 58 & 14.8 & 90 & 11.7 \\
\hline $25-44$ & 78 & 11.9 & 102 & 14.8 & 180 & 13.4 \\
\hline $45-64$ & 130 & 24.7 & 136 & 24.5 & 266 & 24.6 \\
\hline$\geq 65$ & 39 & 21.8 & 81 & 37.7 & 120 & 30.5 \\
\hline
\end{tabular}

Totaal 325 423 748

Uit de tabel blijkt, dat het aanbod toenam met de leeftijd, met een "top" in de klasse 45-64. Er werden meer vrouwen dan mannen gezien. Wordt rekening gehouden met de samenstelling van de praktijkpopulatie, dan stijgt het aanbod nog duidelijker met de leeftijd.

Uit tabel 6.2.1.- 2 is gebleken, dat 56 personen, ruim $10 \%$, gedurende de onderzoeksperiode twee of meer problemen presenteerden. Strikt genomen is thet daarom niet geoorloofd, om personen en problemen in aantal aan elkaar gelijk te stellen. Het lijkt er echter op, dat met de leeftijd ook het aantal personen uit de betreffende leeftijdscategorie met een oogprobleem, stijgt. 
Bovenstaande wordt nogmaals weergegeven voor "refractieproblematiek" respectievelijk "andere oogaandoeningen" in de navolgende drie tabellen.

Tabel 6.2.2.-2: Aanbod an refractieafiwijkingen, respectievelijk "andere oogacndoeningen", gerelateerd aan leefrijd en geslacht van de patiënt* absoluut en als percentage wan de becreffende leefujdsgroep in de praktijk.

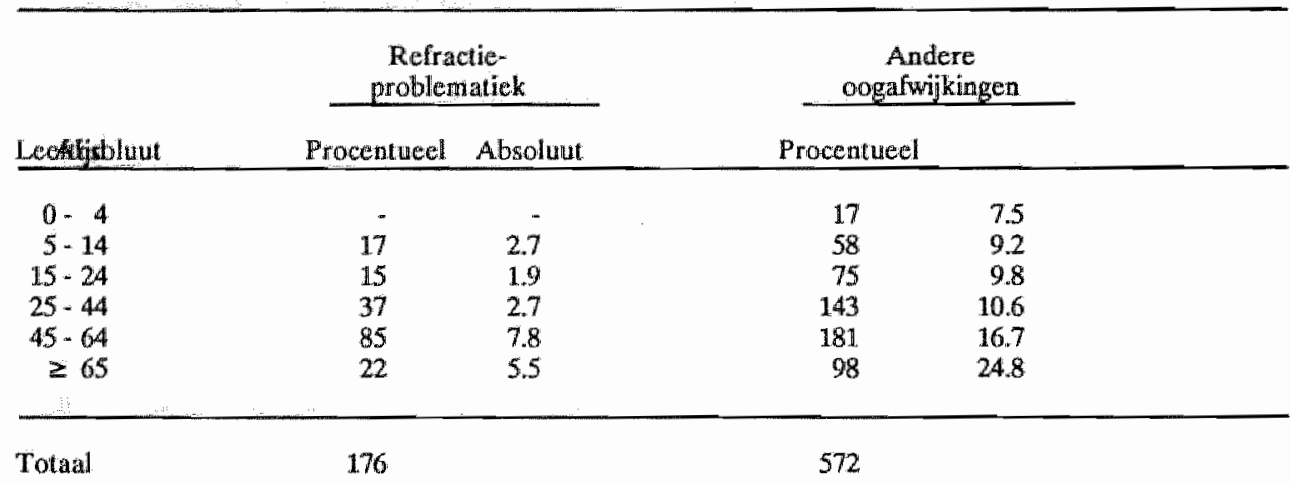

Tabel 6.2.2.- 3: Aanbod aan refractieafwijkinger, gerelaterd aan de leeftijd en het geslocht van de patient; absoluut en als percentage van de betreffende leeftijdsgroep in de praktijk.

\begin{tabular}{|c|c|c|c|c|c|c|}
\hline \multirow[b]{2}{*}{ Leeftijd } & \multicolumn{2}{|c|}{ Mannen } & \multicolumn{2}{|c|}{ Vrouwen } & \multicolumn{2}{|c|}{ Totaal } \\
\hline & Absoluat & Procentueel & Absoluut & Procentueel & Absolutut & Procentueel \\
\hline $0-4$ & - & - & - & - & - & . \\
\hline $5-14$ & 9 & 2.6 & 8 & 28 & 17 & 27 \\
\hline $15-24$ & 6 & 1.6 & 9 & 23 & 15 & 1.9 \\
\hline $25 \cdot 44$ & 14 & 2.1 & 23 & 3.3 & 37 & 2.7 \\
\hline $45-64$ & 33 & 6.3 & 52 & 9.3 & 85 & 7.8 \\
\hline$\geq 65$ & 8 & 4.5 & 14 & 6.5 & 22 & 5.5 \\
\hline
\end{tabular}

Totaal

70

106

176 


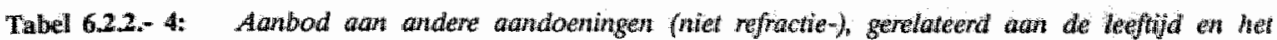

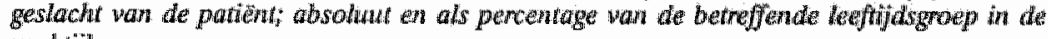
prakijijk.

\begin{tabular}{|c|c|c|c|c|c|c|}
\hline \multirow[b]{2}{*}{ Leefiijd } & \multicolumn{2}{|c|}{ Mannen } & \multicolumn{2}{|c|}{ Vrouwen } & \multicolumn{2}{|c|}{ Totinal } \\
\hline & Absoluvt & Procentueel & Absoluut & Procentueal & Absoluut & Procentueel \\
\hline $0-4$ & 12 & 10.1 & 5 & 4.6 & 17 & 7.5 \\
\hline $5-14$ & 25 & 7.3 & 33 & 11.5 & 58 & 9.2 \\
\hline $15-24$ & 26 & 69 & 49 & 12.5 & 75 & 9.8 \\
\hline $25-44$ & 64 & 9.8 & 79 & 11.5 & 143 & 10.6 \\
\hline $45-64$ & 97 & 18,4 & 84 & 15.1 & 181 & 16.7 \\
\hline$\geq 65$ & 31 & 17.3 & 67 & 31.2 & 98 & 24.8 \\
\hline Totaal & 255 & & 317 & & 572 & \\
\hline
\end{tabular}

Uit tabel 6.2.2.- 2 blijkt, dat de refractieproblematiek ongeveer een kwart van het totaal aan oogheelkundige problemen uitmakkte. Bijna de helft van de refractieproblematiek (85) werd aangeboden door personen uit de leeftijdscategorie 45-64 jaar, Dat betekent naar alle waarschijnlijkheid, dat bijna de helft van het totale aanbod van refractieproblematiek werd bepaald door het presbyopie-probleem. Boven de 65 jaar nam de refractie-problematiek af. Dit was ook te verwachten, gezien het feit, dat verslechtering van de presbyopie (gemiddeld 2.5 dioptrieën in totaal) doorgaans stopt bij het 65 ste jaar.

Uit tabel 6.2 .2 - 3 blijkt, dat vrouwen vaker dan mannen een refractieafwijking hadden. Relatief de meeste afwijkingen kwamen voor in de leeftijdscategorie 45-64 jaar.

Uit tabel 6.2.2.- 4 blijkt, dat eveneens "andere oogaandoeningen" vaker door vrouwen dan door mannen werden aangeboden. Binnen de leeftijdscategorie 65 jaar en ouder werden "andere oogaandoeningen" ruim twee maal zo vaak door vrouwen als door mannen aangeboden.

In tabel 6.2.2.- 5 wordt de leeftijdscategorie 65 jaar en ouder nog eens apart belicht.

Tabel 6.2.2.- 5: Refroctieafwikingen en andere oogaandoeningen bij personen wan 65 jaar en ouder. Absolum en als percentage van het totaal aumal aandoeningen in de legfijdscategorie.

Totral

\begin{tabular}{lccccc}
\hline & & & & \multicolumn{2}{c}{ Total } \\
\cline { 5 - 5 } Hoofddiagnose & Mannen & Vrouwen & & Absoluut & Procentued \\
\hline Refractieafwijking & 8 & 14 & 22 & 1.8 \\
Andere oogaandoening & 31 & 67 & 98 & 82 \\
\hline
\end{tabular}

Totaal

39

81

120

100 
Uit tabel 6.2.2. 5 blijkt het relatief grote aandeel van niet refractie-problemen; tevens wederom het duidelijk grotere aanbod van wrouwen dan van mannen.

6.2.3 Verdeling van het aanbod oogheelkundige problemen maar verzekeringsvorm. Bij indeling naar verzekeringsworm bleek de oogheelkundige problematiek verdeeld, zoals weergegeven in tabel 6.2.3.- 1:

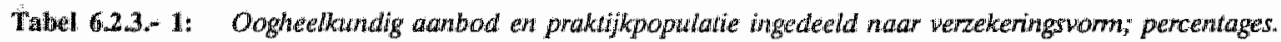

Arinbod

Ziekeniondspathenten

Particullieren
77.9

22.1
Praktijkpopalatie

72.6

27.4

Uit de tabel blijkt, dat de verdeling naar verzekeringsvorm voor het aanbod van oogheelkundige problemen en voor de praktijkpopulatie globaal overeenkwamen.

\subsubsection{Frequentie van oogheelkundige problemen naar selizoen}

Het aanbod aan oogheelkundige problemen per maand vertoonde weinig variatie. Nagegaan is of seizoensinwloeden aanwijsbaar waren. Men zou bijvoorbeeld bij pollinosis een groter aanbod in het voorjaar of de zomer verwachten. Ten aanzien van geen enkele diagnose bleek echter de invloed van het seizoen aanwijsbaar. De aantallen zijn mogelijk te klein om verschillen aan het licht te brengen.

\subsubsection{Nieuwe versus oude problematiek, zoals gepercipieerd door de arts bij aanvang van het eerste consult}

Het aanbod aan oogheelkundige problematiek is onderverdeeld in "nieuw" en "oud", zoals uiteengezet in hoofdstuk 5. Bovendien is een derde categorie problemen onderscheiden, namelijk die, waarbij geen sprake was van oogklachten, maar waarbij op grond van aandoeningen als hypertensie en diabetes door de arts een risico op complicaties van de aandoening met betrekking tot het zien aanwezig werd geacht.

De aantallen problemen voor deze drie categorieën zijn in tabel 6.2.5.- 1 weergegeven.

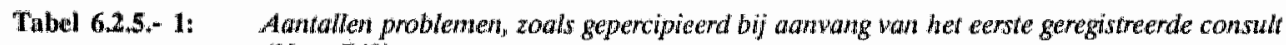
$(N=748)$.

Absolunt

Nieuw oogprobleem

Oud oogprobleem

Algemeen probleem met mogelijke

complicaties t.a.v, het zien
Procentued

70.6

18.0

$\$ 1.4$

Uit deze tabel blijkt, dat het in bijna driekwart van de gevallen bij het eerste geregistreerde consult om een nieuw oogheelkundig probleem ging. Het percentage aandoeningen met mogelijke complicaties ten aanzien van het zien is echter niet onaanzienlijk. 


\subsubsection{Patiënten onder controle bij de oogarts}

Een aantal patiënten was bij aanvang van het eerste consult reeds onder controle van de oogarts, hetzij voor een ander oogprobleem hetzij voor het gepresenteerde oogprobleem. Het aantal patiënten dat bij aanvang van het eerst geregistreerde consult onder controle van de oogarts stond was 14, d.w., $1.9 \%$ van het totaal aantal geregistreerde patiënten.

\subsubsection{Initiatief tot oogonderzoek}

In paragraaf 6.2 .5 is reeds aangegeven, dat in een aantal gevallen oogonderzoek niet plaatsvond op initiatief van de patiënt, namelijk in die gevallen, waarin er een algemene aandoening bestond met mogelijke complicaties m.b.t. het zien. Echter, ook in een aantal andere situaties ging het initiatief tot oogonderzoek niet uit van de patiënt. Bijvoorbeeld indien iets gezien werd aan het oog van de patiënt wat deze nog niet was opgevallen, of in geval van keuringen (door schoolarts, arts consultatieburo, keurend arts). Oogonderzoek bij kinderen op initiatief van de ouders is in dit kader opgevat als initiatief van de patiënt zelf.

In tabel 6.2.7.- 1 wordt weergegeven hoe vaak het initiatief tot een oogonderzoek uitging van de patiënt, van de huisarts dan wel van andere artsen.

In ruim een vijfde van de gevallen was het iemand anders dan de patiënt, voornamelijk de huisarts, die een oogonderzoek noodzakelijk achtte. Eerder is gebleken. (tabel 6.2.5. - 1), dat ruim $11 \%$ van het aantal consulten surveillerend onderzoek bij niet-oogheelkundige aandoeningen (b.v. hypertensie en, diabetes) betrof, steeds op initiatief van de huisarts. In ongeveer $7 \%$ van de gevallen werd oogonderzoek door de huisarts dus op andere gronden noodzakelijk geacht (b.v. een reeds bekend beginnend cataract, marginale oogdrukken).

Tabel 6.2.7. 1: Initiatief tot oogonderzoek $(N=748)$.

Absolluut

Patiënt

Huisarts

Andere artsen
588

137

23
Procentueel

78.6

18.3

3.1

In hoofdstuk $8 \mathrm{zal}$ de opbrengst aan diagnostiek voor wat betreft klachten van de patiënt enerzijds en oogonderzoek op initiatief van de huisarts anderzijds afzonderlijk worden belicht. 


\subsection{Controle op de juistheild van de gestelde diagnosen; verwijzingen en follow-up}

\subsubsection{Criteria voor de juistheid van de gestelde diagnosen}

De waarde van een preventief en therapeutisch beleid zal in grote mate afhangen van de juistheid van de gestelde diagnosen. De diagnosen dienen derhalve op hun juistheid te worden getoetst. Daarvoor dient men te beschikken over een "Gouden Standaard" als referentiepunt. Deze is echter veelal niet voorhanden, ook in dit onderzoek niet. Als "goede standaard" werd gehanteerd:

- indien de patient werd verwezen naar de oogarts: het oordeel van de oogarts naar wie werd verwezen.

- indien de patiënt niet naar de oogarts werd verwezen: aan- of afwezigheid van gegevens op de patienten-kaart in de periode volgend op de geregistreerde consulten (follow-up), welke betrekking hadden of zouden kunnen hebben op het betreffende oogheelkundige probleem.

Door deze keuze wan "goede standaarden" komt de onjuistheid van diagnosen betreffende verschillende "self-limiting" aandoeningen niet aan het licht. Bijvoorbeeld, de diagnose virale conjunctivitis kan zijn gesteld, waar het een bacteriële conjunctivitis betrof. Beide verdwijnen vanzelf. Een dergelijke "fout" is echter ook van weinig klinisch belang.

Het totaal aantal verwijzingen wordt in tabel 6.3.1.* 1 weergegeven. De verwijzingen naar de oogarts, welke werden geëffectueerd na de registratieperiode doch betrekking hadden op een probleem, dat tijdens de registratieperiode aan de orde was geweest, zijn hierbij meegeteld.

Uit tabel 6.3.1.- 1 blijkt, dat een derde van het aantal problemen werd verwezen, doch slechts $11 \%$ naar de oogarts. Tweemaal zoveel problemen werden verwezen naar de opticien.

Tabel 63.1.- 1: Aantales problemen dat werd verwezen naar de werschillende instanties, absoluat en procentueet.

Absoluut

Nict verwezer

Verwezen natar: opticien

oogarts

andere specialist.

Reeds onder behandeling (oogarts, andere specialist)

$\begin{array}{rr}486 & 66 \\ 160 & 21 \\ 81 & 11 \\ 10 & 1\end{array}$

11

Totall

748

100

Tabel 6.3.1.- 2 laat zien, welke de diagnosen/hypothesen waren bij de 81 naar de oogarts verwezen patiënten. 
Tabel 63.1.-2.: Diagnosen c.q. hypothesen bil patienten ventezen narar de oogarts.

Hoofddiagnose

Aantal

Visuswermindering t.g.w. refractieafwijking

Cataract

Totaal geen afwijkingen

Misschien primair chronisch glaucoom

Waarschijnlijk primair chronisch glaucoom

Visusvermindering niet t.g.v. een refractieafwijking

Diabetische retinopathie

(Mogelijk) strabisme

Vasculaire retinopathie

Tumor in de conjunctiva

21

Restgroep sclera-afwijkingen

Maculaafwijkingen

Conjunctivitis

Chalazion

Wratje oogleden

Secundair glaucoom

Restgroep retina-afwijkingen

Restgroep cormearafwijkingen

Ophthalmia neonatorum

Glasvochtmembraanloslating.

Geen oogstandafwijkingen

Geen visusvermindering; goed gecorrigeerd

Geen corpus vitreum afwijkingen

Geen diabetische retinopathic

Entropion

Acute uveitis anterior

Totaal

1

Uit tabel 6.3.1.- 2 blijkt, dat de verwijsindicaties zeer divers van aard zijn. Ongeveer een kwart van de verwijzingen betreft visusvermindering ten gevolge van een refractieafwijking. De negatieve diagnosen wijzen hetzij op het verzoek

van de patiểnt alsnog te worden verwezen, hetzij op een hypothese, waarvan de arts nadere bevestiging wenste.

\subsubsection{Controle op de juistheid van de gestelde diagnosen aan de hand van de terugrapportage van de oogarts}

Er werd op toegezien, dat van elke verwezen patiënt een terugrapportage van de oogarts werd ontvangen, hetzij per brief, hetzij telefonisch.

De verwijsindicatie c.q. diagnose is vergeleken met de door de oogarts gestelde diagnose. Op geleide hiervan is een oordeel toegekend aan de verwijsindicatie, in de zin van al dan niet correct.

Van de 81 personen die volgend op het eigen onderzoek werden verwezen naar de oogarts, geschiedde de werwijzing in 13 gevallen op uitdrukkelijk verzoek van de patiënt. In geen van deze 13 gevallen week het oordeel van de oogarts af van dat van de huisarts- onderzoeker. 
21 van de overige 68 verwijzingen naar de oogarts vonden plaats, omdat er bij de huisarts onduidelijkheid over de diagnose bestond. De rest van de verwijzingen vond plaats, omdat therapeutisch ingrijpen door een oogarts noodzakelijk werd geacht.

Tabel 6.3.2.- 2 geeft een overzicht van de 21 diagnosen, die als werkhypothese dan wel als nader te specificeren probleenl aan de oogarts werden voorgelegd.

Tabel 63.2, 2: Verwezen naar de aogars woor nadere diagnostiek.

Diagnose c.g. bypothese

Misschien of waarschijnlijk glawcoom

Gecompliliceerd refractieprobileem

Melanoom van de conjunctiva

Maculadegeneratie

Glasvochtmembraanloslating

Metastasen in fundo

Niet te verklaren pijn bij contactlensdrager

Ophthalmia neonatorum
Aantal

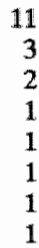

21
11

3

2

1

1

1

1

Totaal

Uit tabel 6.3.- 2 blijkt, dat vooral glaucoomproblematiek ten behoeve van verdere diagnostiek naar de oogarts werd verwezen.

Bij acht oogproblemen bestond er een discrepantie tussen het oordeel van de oogarts en dat van de onderzoeker. De bijbehorende ziektegeschiedenissen werden volledig uitgeschreven en ter beoordeling voorgellegd aan een andere oogarts. Naar het oordeel van deze laatste waren de verschillen geen van alle klinisch relevant.

Samenvattend kan men concluderen, dat de diagnose van de oogarts in geen van de gevallen een (terechte) ontkenning vormde van de diagnose van de huisarts/onderzoeker.

\subsubsection{Controle op de juistheid van de gestelde diagnosen bij niet verwezen problemen} aan de hand van de notities op de "groene kaart".

De periode gedurende welke de gegevens zijn nagetrokken besloeg ongeveer $31 / 2$ jaar. Indien uit de gegevens op de "groene kaart" volgend op de geregistreerde consulten bleek, dat sprake moest zijn geweest van een andere aandoening dan door de onderzoeker werd vermoed, dan zou de kwalificatie "niet correct gestelde diagnose" worden gegeven. Hetzelfde gold voor het gevoerde beleid.

Uit de follow-up is echter geen enkele maal een aanwijzing gevonden voor een nietcorrecte diagnose.

\subsection{Samenvatting en conclusies}

In totaal werden in anderhalf jaar 748 oogproblemen gepresenteerd. Voor een normpraktijk zou dat een aantal van ongeveer 250 per jaar opleveren, hetgeen neerkomt op ongeveer é̂n oogprobleem per werkdag. Ruim $80 \%$ van de problemen behoefde slechts éen huisartsconsult. $10 \%$ werd na én consult naar de oogarts verwezen. 
Ouderen met oogproblemen waren duidelijk oververtegenwoordigd. Een derde van het aanbod kwam uit de groep personen van 65 jaar en ouder, waarbij in veruit de meeste gevallen een andere diagnose dan "refractieafwijking" als hoofddiagnose werd gesteld. Gezien de ondervertegenwoordiging van vrouwen boven 65 jaar in de praktijkpopulatie is er mogelijk nog sprake van een onderschatting de incidentie van aandoeningen in deze groep. Refractieafwijkingen kwamen het meest voor in de leeftijdscategorie 45-64 jaar. Daarbij ging het bijna uitsluitend om presbyopie.

De door de patiënt aangeboden oogproblematiek betrof in $70 \%$ der gevallen een nieuw probleem. In $80 \%$ der gevallen vond oogonderzoek plaats op initiatief van de patiënt. Oogonderzoek op initiatief van de huisarts, $18 \%$ in totaal, werd in ongeveer $11 \%$ verricht bij patiënten met aandoeningen als diabetes en hypertensie en in ongeveer $7 \%$ bij patiënten met van tevoren bekende beginstadia van oogaandoeningen, zoals marginale oogdrukken en beginnend cataract. Het aandeel van activiteiten gericht op preventie was dus niet onaanzienlijk.

In totaal werd $11 \%$ van de problemen verwezen naar de oogarts, het dubbele daarvan naar de opticien. Van de 81 verwijzingen naar de oogarts geschiedde $16 \%$ op uitdrukkelijk verzoek van de patiënt; $26 \%$ werd verwezen wegens onzekerheid van de huisarts omtrent de diagnose of wegens de onmogelijkheid de diagnose nader te specificeren. Hierbij betrof het vooral een verdenking op glaucoom op grond van verhoogde oogdruk of oogdrukverschillen, waarbij bepaling van het gezichtsveld wensellijk werd geacht.

Toetsing van de gestelde diagnosen aan de hand van de terugrapportage van de oogarts en aan de hand van de eigen gegevens (patiëntenkaart) in de follow-upperiode, wees uit, dat er geen sprake was van klinisch relevante foutieve diagnosen. 


\section{Hoofdstuk 7}

\section{MORBIDITEITSREGISTRATIES}

\subsection{Inleiding}

In paragraaf 7.1 wordt een overzicht gegeven van de diagnosen, die gedurende de periode van registratie werden gesteld.

Wat betreft de diagnosen c.q. bevindingen in de eigen registratie is onderscheid gemaakt in nieuwe bevindingen en oude bevindingen:

- nieuwe bevindingen zijn die welke vór de registratie niet bekend waren aan de huisarts. Deze zijn omgerekend naar aantal per 1000 ingeschreven personen per jaar, resulterend in een incidentiecijfer.

- oude bevindingen zijn bevindingen die voor de registratieperiode reeds bekend waren bij de oogarts dan wel bij de onderzoekende huisarts en waarmee de patiënt gedurende de registratieperiode nogmaals op het spreekuur kwam. Prevalenties konden niet worden berekend. Immers, de patiënten ontbraken die onder controle van de oogarts stonden en zich in de registratieperiode niet bij de huisarts meldden. In paragraaf 7.2 wordt een vergelijking gemaakt met andere morbiditeitsregistraties. De paragrafen 7.3 en 7.4 bevatten een analyse respectievelijk conclusies naar aanleiding van de gegevens.

\subsection{Diagnosen en incidenties}

De volledige lijst van gestelde diagnosen, nieuw, respectievelijk oud en de daaruit resulterende incidentielijst, is opgenomen in bijlage $\mathrm{V}$.

Tabel 7.1.- 1 bevat een gecomprimeerde versie, waarin de incidenties worden weergegeven van de verschillende diagnosegroepen, voor zover mogelijk ingedeeld nalar anatomisch substraat.

De incidenties van potentieel gevaarlijke aandoeningen worden apart vermeld. 
Tabel 7.1.- 1: Incidenties per diognosegroep en incidenties van potentieel gevaardike aandoeningen (cursief gedinkt).

\begin{tabular}{ll} 
Diagnosegroep & $\begin{array}{c}\text { Incidentie van } \\
\text { Incidentie } \\
\text { diagnosegroep }\end{array}$ \\
aandoeningen \\
\hline
\end{tabular}

Refractieprobiematiek

Oogleden

Bleforitis herpetica

Traanwegen

Conjunctiva

Ophthatria neonatomn

Melanoom

Cornea

Keratitis dendritica

Keratitis marginalis

Keratitiss punctala

Sclera

Uvea

Acute aveitus anterior

Ooglens

Corpus vitreum Glasvochubloeding

Fundus hypertonicus

Bloedingen Cotton wools

Diabetische retinopathic

Bloedingen + exsudaten

Vaatproliferaties

Arteriosclerotische fundus.

Andere vactpathologie in fundo

Afwilkingen in macula

Papiloedeem

Glaucoom

Misschien glaucoom

Waarschijnlijk glaucoom
28.3

8.1

1.3

19.9

0.3

1.6

1.9

0.1

1.1

8.6

2.6

7.1

0.8

0.1

2.6

3.8

3.4
0.1

1.2

0.3

0.4

0.6

1.6

0.1

0.6

0.4

Wat met name opvalt is, dat bijna het hele palet aan mogelijke oogaandoeningen in de registratie voorkwam, zij het dat de meeste aandoeningen een lage incidentie hebben. Refractieafwijkingen en aandoeningen van de conjunctiva kwamen het meest frekwent voor, alle fundusafwijkingen tesamen kwamen op de derde plaats.

Bij een aantal aandoeningen verschillen de incidenties bij mannen en vrouwen duidelijk. Tabel 7.1.- 2 geeft de betreffende incidenties weer voor mannen en vrouwen apart.

De meeste aandoeningen, waarbij de incidenties geslachtsverschillen vertoonden, kwamen meer bij vrouwen voor dan bij mannen. Alleen corpora aliena werden meer bij mannen gezien, zeer waarschijnlijk te verklaren uit verschillen in beroep en vrijetijdsbesteding.

De refractieproblematiek en gering dan wel duidelijk cataract kwamen opvallend vaak meer bij vrouwen voor. Deze bevinding is ook in andere registraties terug te 
vinden. Een verklaring hiervoor wordt nergens gegeven. Wellicht ondervinden vrouwen bij het handwerken eerder hinder van slecht zien dan mannen.

Ook blefaritis kwam meer bij vrouwen voor dan bij mannen evenals keratitis marginalis en keratitis punctata. Deze beide laatste aandoeningen kunnen als complicatie voorkomen bij een chronische blefaritis. Een duidelijke verklaring voor het gevonden geslachtsverschil is er echter niet.

Tabel 7.1.- 2: Oagaandoeningen met een duidelijk werschill in incidentie bij mannen en urouwen.

\begin{tabular}{lrr} 
& Mannen & Vrouwe \\
\hline Refractieproblematiek & 22.5 & 34.0 \\
Blefaritis & 0.1 & 2.7 \\
Keratitis marginalis & 0.9 & 2.4 \\
Keratitis punctata & 0.9 & 3.0 \\
Cataract & 2.7 & 5.3 \\
Gering cataract & 1.5 & 7.7 \\
Corpus alienum & 1.9 & -
\end{tabular}

\subsection{Vergelijking met andere morbiditeitsregistraties}

De eigen cijfers zullen worden vergelleken met de cijfers uit het monitoringproject van Ommoord, periode 1-5-79 tot 1-5-81 (Lamberts 1984), de CMR van Nijmegen, periode 1978-1982 (Nijmeegs Universitair Huisartsen Instituut 1985) en de registratie van Oliemans, periode 1967-1968 (Oliemans 1969), en Hodgkin, periode 1967-1971 (Hodgkin 1978).

Bij vergelijking van morbiditeits-statistieken doet zich het probleem voor, dat de diagnostische criteria gebruikt door de verschillende onderzoekers niet altijd dezelfde zijn. Lamberts gaat uit van de ICHPPC-2, Nijmegen en Oliemans van de E-lijst van het Royal College of General Practitioners, Hodgkin gebruikt de ICD-8 en waar mogelijk het equivalente codenummer van de E-lijst.

Het is daarom onmogelijk om alle gegevens in één vergelijkend overzicht onder te brengen. Derhalve zullen de gegevens van de verschillende registraties afzonderlijk worden gepresenteerd, afgezet tegen de gegevens uit dit onderzoek.

Omdat in het onderhavige onderzoek een meer gedifferentieerde registratie betreffende oogaandoeningen is gehanteerd dan in alle genoemde onderzoeken, zal dikwijls een "samengesteld" incidentie-cijfer worden gepresenteerd. Bijvoorbeeld: waar in het overzicht van Lamberts het incidentie-cijfer voor "infecties oogleden" wordt vermeld, worden ter vergelijking in het eigen bestand de cijfers voor "chalazion", "hordeolum", "blefaritis" en "herpes-infectie van de oogleden" samengenomen.

Ter verduidelijking zal dit in de tabellen in een aparte kolom worden vermeld, met daarin aangegeven, uit welke afzonderlijke incidentiecijfers het totaal-cijfer uit het eigen onderzoek is samengesteld.

Tevens is in elke tabel een aparte "restcategorie" opgenomen. Deze categorie bevat aandoeningen, voorkomend in het eigen bestand, die niet kunnen worden ondergebracht in één van de categorieëen van de registratie waarmee wordt vergeleken. Per vergelijking verschilt de restcategorie van inhoud, wegens het verschil in indeling van de andere registraties. De aandoeningen die telkens in de restcategorie 
zjjn opgenomen staan met bijbehorende incidentiecijfers vermeld in bijlage VI. Vermeld dient te worden, dat in de bovengenoemde morbiditeitsregistraties in geval van verwijzing, de diagnose werd geregistreerd c.q. gecorrigeerd na terugrapportage door de oogarts. In het eigen onderzoek was dit niet het geval. Uit hoofdstuk 6 bleek echter, dat de diagnose van de oogarts in geen enkel geval wezenlijk verschilde van die van de huisarts. Alleen bij de diagnose glaucoom werden door de oogarts "definitievere" uitspraken gedaan.

Lamberts vermeldt twee incidentiecijfers, namelijk aparte cijfers voor de twee opeenvolgende jaren van het onderzoek. Ook Hodgkin vermeldt twee getallen. Hier geeft het eerste getal het aantal gevallen aan, waarbij hij zeker is van de diagnose, in het tweede getal zijn ook de twiffelgevallen verdisconteerd.

In tabel 7.2.- 1 worden de incidentie-cijfers uit dit onderzoek vergeleken met die wan Oliemans en Nijmegen (CMR).

Tabel 7.2.- 2 geeft de wergelijking met de registraties zoals gerapporteerd door Lamberts.

In tabel 7.2.- 3 wordt de eigen registratie vergeleken met die van Hodgkin.

Tabel 7.2.- 1: Vergelijking van incidenticejijters van Oliemans (1) en Nijmegen (1978-1982) (2) met die uit eigen onderzoek (3); toelichting op de samenstelling van het eigen totaalcijfer per categorie.

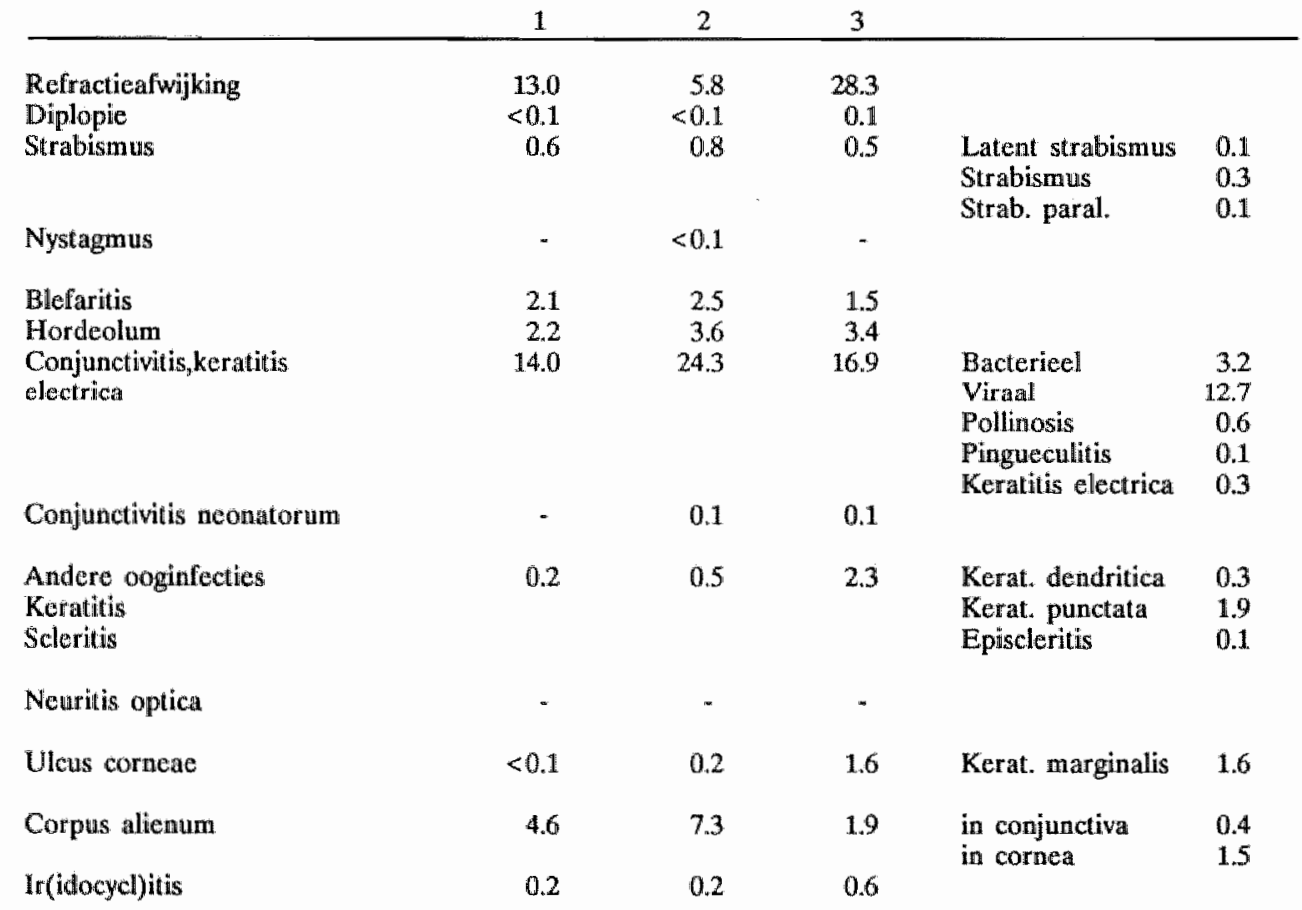


Venolg tabel $7.2-1$

$\begin{array}{lcccll}\begin{array}{l}\text { Ontsteking traanklier, } \\ \text { Stenosis traanwegen. }\end{array} & 0.4 & 0.7 & 0.1 & \text { alleen stenosis } \\ \text { Cataract } & 0.5 & 1.7 & 8.6 & \begin{array}{l}\text { gering cattaract } \\ \text { duidelijk cataract }\end{array} & 4.0 \\ & & & & & \\ \text { Glaucoma } & <0.1 & 0.3 & 3.8 & \begin{array}{l}\text { misschien } \\ \text { warschijnlijk }\end{array} & 3.4 \\ & & & & 0.4 \\ \text { Rest } & 23.5 & 3.7 & 21.7 & \begin{array}{l}\text { 24 diagnosen } \\ \text { (bijlage VI) }\end{array}\end{array}$

Tabell 7.2.- 2: Vergelijking van incidentiecijers van Lambents (1) met die uit het eïgen onderzoek (2); toelichting op de samenstelling van het eigen totaalcijfer per categorie.

\begin{tabular}{|c|c|c|c|c|}
\hline & 1 & 2 & & \\
\hline Refracticprobleem & $6.8-7.9$ & 28.3 & & \\
\hline Virale conjuncivitis & $0.8=0.9$ & 12.7 & & \\
\hline $\begin{array}{l}\text { Conjunctivitis, } \\
\text { Ophthalmia }\end{array}$ & $22.0-22.1$ & 4.0 & $\begin{array}{l}\text { Bact. conj, itis } \\
\text { Ophthalmila neon. } \\
\text { Pollinosis } \\
\text { Pingueculitis }\end{array}$ & $\begin{array}{l}3.2 \\
0.1 \\
0.6 \\
0.1\end{array}$ \\
\hline $\begin{array}{l}\text { Infecties oogleden, } \\
\text { Chalazion }\end{array}$ & $6.5-7.0$ & 5.4 & $\begin{array}{l}\text { Chalazion } \\
\text { Hordeolum } \\
\text { Blefaritis } \\
\text { Herpesinfectie }\end{array}$ & $\begin{array}{l}0.4 \\
3.4 \\
1.5 \\
0.1\end{array}$ \\
\hline Corpus alienum & $1.9-2.1$ & 1.9 & $\begin{array}{l}\text { in conjunctiva } \\
\text { in contea }\end{array}$ & $\begin{array}{l}0.4 \\
1.5\end{array}$ \\
\hline Stenosis traanwwegen & $0.0 \cdot 0.1$ & 0.1 & & \\
\hline Cataract & $1.0 \cdot 1.4$ & 86 & $\begin{array}{l}\text { gering cataract } \\
\text { Cataract }\end{array}$ & $\begin{array}{l}4.0 \\
4.6\end{array}$ \\
\hline Glaucoom & $0.2-0.5$ & 3.8 & $\begin{array}{l}\text { misschien glauc. } \\
\text { waarschl glauc. }\end{array}$ & $\begin{array}{l}3.4 \\
0.4\end{array}$ \\
\hline Andere oogziekten & $6.3-6.6$ & 26.8 & \multicolumn{2}{|c|}{$\begin{array}{l}\text { restcategorie, } \\
32 \text { diagnosen, bijlage v1 }\end{array}$} \\
\hline Blind & $0.1-0.2$ & 2.2 & slechtziend/blind & 2.2 \\
\hline
\end{tabular}




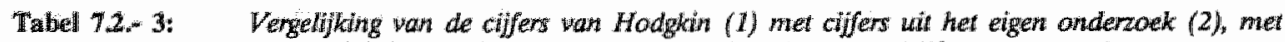
eien toelichting op de sameristelling wan het eigen totalciffer per categorie.

1

Refractie problemen

Strabismus

Blefaritis

Hordeolum

Conjunctivitis,

Keratitis electrica

Subconjunctiwale bloeding

Ulcus corneae

Jridocyclitiss

Stenosis traanwegen

Cataract

Glaucoom

Vaataccident in het oog

Restcategorice
$10.4-12.5$

$1.5-4.3$

$4.9-10.6$

$4.9 \cdot 18.8$

$21.3-32.0$

1.8

$0.4-1.1$

$0.3 \cdot 0.4$

0.3

$3.4-4.1$

$0.3-0.9$

0.1

0.1

25.1

283

0.5

15

3.4

17,0

0.9

0.6

0.1

8.6

3.8
Latent strabismus

Strabismus

0.1

Str.paralyticus!

0.1

Bact.conj.itis j.

3.2

Ophthalmia neon. 0.1

Virale conj.

12.7

Pollinosis

0.6

Pingueculitis

0.1

Keratitis electrica

0.3

1.6 Kerat. marginalis

1.6

gering cataract 4.0 duidelijk cataract $\quad 4.6$

misschien glauc. $\quad 3.4$ waarschl glauc.

0.4

bloeding

corpus vitreum

27 diagnosen

bijlage VI 


\subsection{Analyse van de gegevens uit paragraaf 7.2}

Het incidentiecijfer voor refractieproblemen verschilt per registratie aanmerkelijk, zoals tabel 7.3.- 1 nogmaals laat zien.

Tabel 73.- 1: Incidentie van refractieproblemen voor de verschillende registraties.

Registratie

Oliemans

Nijimegen

Lamberts

Hodgkin

Eigen onderzock
Incidentie

13.0

5.8

$6.8-7.9$

$10.4-12.5$

28.3

Het cijfer uit de eigen registratie ligt ruim twee maal zo hoog als het hoogste cijfer van de anderen. Hiervoor zijn verschillende verklaringen aan te geven:

In Nijmegen en in Ommoord gaan wellicht veel patiënten rechtstreeks naar de opticien zonder tussenkomst van de huisarts, zoals vaak te doen gebruikelijk. In de eigen praktijk wordt deze gang van zaken al jaren lang zoveel mogelijk "ontmoedigd".

Een deel van de verklaring is mogelijk gelegen in het feit, dat in de eigen registratie ook die refractieproblemen als "nieuw" zijn geregistreerd, die weliswaar al bekend waren - de patiënt was brildragend - maar die bij onderzoek zodanig verergerd bleken te zijn, dat aanpassing van de brilleglazen noodzakelijk was. Deze groep refractieproblemen is door de anderen als "oud probleem" bestempeld.

Verder is gebleken, dat in het eigen onderzoek door grondige screening patienten met refractieproblemen werden opgespoord, die zich van deze afwijking niet bewust waren en daarover dus ook niet klaagden. Hierop wordt nader ingegaan in hoofdstuk 8.

De cijfers voor de verschillende infectieuze aandoeningen van de oogleden, conjunctiva en cornea tonen nog opmerkelijker verschillen. Van de andere onderzoekers vermeldt alleen Lamberts de virale conjunctivitis apart, maar met een onwaarschijnlijk laag incidentiecijfer in vergelijking met het eigen onderzoek. Men zou de conclusie kunnen trekken, dat het onderscheid tussen bacteriële, virale en allergische conjunctivitiden, moeilijk is te maken, hetgeen ook overeenkomt met de eigen ervaring. Het onderscheid, gemaakt in het eigen onderzoek is daarom ook niet geheel valide.

Op welke manier de verschillende auteurs de kwalificatie "het rode oog" nader specificeren laat tabel 7.3.- 2 zien.

Met conjunctivitis neonatorum (Oliemans, Nijmegen) wordt waarschijnlijk, gezien het lage incidentiecijfer van 0.1 , bedoeld de ophthalmia neonatorum, welke ziekte inderdaad weinig voorkomt. Dit in tegenstelling tot de banale conjunctivitis bij zuigelingen, die frekwent voorkomt. 


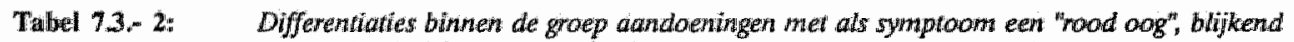
uit incridentiectiffers; exclusiof infecties oogleden, initis en corpus alienum.

\begin{tabular}{|c|c|c|c|c|c|}
\hline & Oliemans & Nijmegen & Lamberts & Hodgkin $^{2}$ & Baggen \\
\hline Conjumetrivitis totaal & 14.0 & 24.3 & 23.0 & 32,0 & 16.5 \\
\hline - viraal & & & 0.9 & & 12.7 \\
\hline - totaal minus wiraal & & & 22.1 & & \\
\hline bacterieel & & & & & 3.2 \\
\hline allergisch. & & & & & 0.6 \\
\hline Kevatelectrica + conj.itis neon. & & 0.1 & & & \\
\hline - Keratitis electrica & & & & & 0.3 \\
\hline Ophthalmia neonatorum & & & & & 0.1 \\
\hline Ulcus corneae & 0.1 & 0.2 & & 1.1 & \\
\hline Ontsteking traanklier & 0.4 & 0.7 & & & \\
\hline Stenosils traanwegen & & & & 0.3 & \\
\hline Pingueculitis & & & & & 0.1 \\
\hline Keratitis dendritica & & & & & 0.3 \\
\hline Keratitis punctata & & & & & 1.9 \\
\hline Keratitis marginalis & & & & & 1.6 \\
\hline Kalkconcrementen in de conjunctiva & & & & & 0.6 \\
\hline Episcleritis & & & & & 0.1 \\
\hline T'richiasis & & & & & 0.6 \\
\hline Entropion & & & & & 0.1 \\
\hline Siccasyndroom & & & & & 0.9 \\
\hline Vaatingroei i/d cornea & & & & & 0.1 \\
\hline Rest & 0.2 & 0.5 & & & \\
\hline
\end{tabular}

Totaal

14.7

25.8

22.9

33.1

23.2

Het gemiddelde van twee opeenvolgende jaren

Zekere plus onzekere diagnosen.

Het totaal van de categoriëen met als gemeenschappelijk kenmerk een rood oog, ligt gemiddeld rond de 25 . De spreiding is echter groot. De differentiëring binnen het eigen onderzoek is aanzienlijk groter dan bij de anderen. De mate waarin deze differentiëring zinvol is met betrekking tot de therapie wordt geillustreerd aan de hand van tabel 7.3.- 3. Bij 12 van de 14 gestelde "rode oog"- diagnosen blijkt de therapie anders dan de meestal voorgeschreven antibiotica in oogzalf/oogdruppels.

Opvallend zijn bij Hodgkin de relatief hoge incidentiecijfers woor blefaritis, conjunctivitis, en hordeolum. Een verklaring ligt niet direkt voor de hand. Het meest aannemelijk is nog, dat in de vijftiger jaren infecties aan het uitwendige oog zich meer endemisch manifesteerden.

Opmerkelijk is het eigen lage cijfer voor corpus alienum. Mogelijk spelen streekverschillen voor wat betreft industrie en dergelijke, een rol. Ook is mogelijk, dat de meeste mensen met een corpus alienum in het oog rechtstreeks naar de eerste hulp van het plaatselijke ziekenhuis zijn gegaan. 


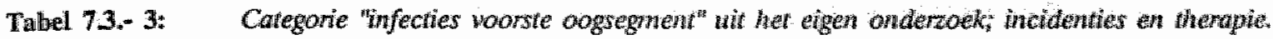

\begin{tabular}{|c|c|c|}
\hline Cattegorie & Incidentie & Therapie \\
\hline Conjunctivitis & 15.9 & antibiotica \\
\hline Pollinosis & 0.6 & cromoglycal \\
\hline Pingueculitis & 0.1 & conticosteroiden * antibiotica \\
\hline Keratitis electrica & 0.3 & antibiotica \\
\hline Ophthalmia neonatorum & 0.1 & met spoed naar oogarts \\
\hline Keratitis dendritica & 0.3 & acyclowir \\
\hline Keratitis punctata & 1.9 & oppervlakkig-werkende cortico's \\
\hline Keratitis marginalis & 1.6 & corticosteroiden + antibiotica \\
\hline Kalkconcrementen $\mathrm{i} / \mathrm{d}$ conjunctiva & 0.6 & verwijdaren. \\
\hline Episcleritis & 0.1 & corticosteroiden + antibiotica \\
\hline Trichiasis & 0.6 & epileren \\
\hline Entropion & 0.1 & naar oogarts \\
\hline Sicca syndroom & 0.9 & traanwervangende middelen \\
\hline Vaatingroei cornea & 0.1 & adviezen t.a.v. contactlenzen \\
\hline
\end{tabular}

De categorie traanwegen scoort in het eigen onderzoek in vergelijking met de andere registraties opvallend laag. Een mogelijke verklaring ligt in het feit, dat in het eigen onderzoek geen consultatiebureau-contacten zijn opgenomen. Verder zijn pussende oogjes van de zuigeling in het eigen onderzoek geregistreerd als conjunctivitis en niet als stenosis van de traanwegen, terwijl dat bij de andere mogelijk wel het geval is. Onder stenosis traanwegen wordt in het eigen onderzoek alleen verstaan: tranende ogen bij volwassenen, waarbij de proef van Anel negatief (afwijkend) uitvalt, dat wil zeggen: bij het door-spuiten van het traankanaal blijkt het kanaal niet doorgankelijk.

De incidenties uit de verschillende registraties voor cataract worden in tabel 7.3.4 nogmaals weergegeven.

Tabel 73.- 4: Incidenties woor cataract uit de verschillende registraties.

Onderzoker

Oliemans

Nijmegen

Lamberts

Hodgkin

Eigen onderzoek

- gering

- duidelijk
Incidentic

0.5
1.7
$1.0-1.4$
$3.4-4.1$
8.6

$\quad 4.0$
4.6

Opmerkelijk is het relatief hoge getal voor cataract in het eigen onderzoek. Het gebruik van de spleetlamp is een van de mogelijke verklaringen voor het gevonden werschil. Hiermee worden met name ook geringe lens-troebelingen waargenomen. 
De verschillende incidentiecijfers voor glaucoom worden weergegeven in tabel 7.3.- 5 .

Tabel 7.3.= 5: Incidentiecijfers voor glaucoom bij de verschillende onderzoekers.

Onderzoeker

Oliemans

Nijmegen:

Lamberts

Hodgkin

eigen onderzoek

- misschier

- waarschinjnilijk
Incidentie

$<0.1$
0.3
$0.2-0.5$
$0.3-0.9$
3.8
$\quad 3.4$
0.4

Opvallend is weer het hoge cijfer in het eigen onderzoek. Er dient echter rekening gehouden te worden met het feit, dat het eigen ciffer de resultante is van misschien respectievelijk waarschijnlijk (primair chronisch) glaucoom, een en ander, ongeacht de uiteindelijke diagnose van de oogarts. Als criteria werden daarbij gehanteerd: verhoogde oogdruk; te groot verschil in oogdruk tussen beide ogen; te groot verschil in oogdruk op verschillende tijdstippen; een verdachte C/D-ratio van de papil.

Ten behoeve van de vergelijking is nagegaan in thoeveel gevallen het eigen vermoeden op glaucoom werd bevestigd door de oogarts in die zin, dat deze ofwel de kwalificatie "verdacht voor glaucoom" ofwel de kwalificatie "zeker glaucoom" toekende. Het oordeel van de huisarts, het aantal verwezenen en het oordeel van de oogarts worden weergegeven in tabel 7.3.- 6.

Tabell 7.3.- 6: Aantal malen oog onderzoch op glaucoom; werdenking op het bestaan van glaucoom: oordeel wan huisants en oogaris.

\begin{tabular}{lccccc}
\hline & & & \multicolumn{3}{c}{ Oordeel oogarts } \\
\cline { 5 - 6 } Oordeal thuisarts & $\begin{array}{c}\text { Aantal } \\
\text { onderzocht }\end{array}$ & $\begin{array}{c}\text { Aantal } \\
\text { verwezen }\end{array}$ & Zeker Verdacht & Geen \\
\hline Waarschijnlijk geen glaucoom & 218 & 0 & - & - & - \\
Misschien glaucoom & 23 & 8 & 2 & 1 & 5 \\
Waarschijnlijk wel glaucoom & 3 & 3 & 2 & 1 & - \\
\hline Totaal & 244 & 11 & 4 & 2 & 5
\end{tabular}

Indien "verdacht" op glaucoom tot glaucoom wordt gerekend, dan hadden van de elf naar de oogarts verwezen patienten zes een glaucoom. Dat resulteert in een incidentie van 0.9. Daaruit blijkt, dat ook het eigen gecorrigeerde cijfer voor glaucoom hoger ligt dan dat van de meeste anderen. Alleen Hodgkin komt in zijn categorie van nietzekere diagnosen tot eenzelfde cijfer. 
Aangezien de aandoening primair chronisch glaucoom pas in een zeer laat stadium klachten geeft ligt het voor de hand te veronderstelien, dat een hoger incidentie-cijfer voor een groot deel te danken is aan een meer op preventie gerichte benadering. Bij de niet verwezen patiënten met de diagnose "misschien glaucoom" (15) is uit followup gegevens niet gebleken, dat verwijzing wegens verdenking op glaucoom alsnog noodzakelijk was. In dit verband is het ook belangrijk op te merken, dat bij 218 patiënten gericht gezocht is naar tekenen van glaucoom, maar dat deze niet werden gevonden (diagnose: "zeer waarschijnlijk geen glaucoom"). Tot april 1989 is bij geen van deze patienten de diagnose glaucoom gesteld.

Het incidentiecijfer voor blindheid ligt bij Lamberts, de enige van de andere auteurs die deze categorie hanteert, aanzienlijk lager dan in het eigen onderzoek: $0.1-0.2$ versus 2.2. Een verschil. in gehanteerde criteria is hier de meest waarschijnlijke verklaring. Volgens de WHO-definitie is van blindheid sprake bij een visus van het beste oog van 2/60 of minder (Breebaart 1983). Bij een visus minder dan 0.4 van het beste oog spreekt men van slechtziendheid. In het eigen onderzoek zijn blindheid en slechtziendheid samengenomen, met als reden dat het maken van onderscheid hier tussen klinisch weinig zinvol is. Het is waarschijnlijk, dat Lamberts slechtziendheid niet onder de categorie blindheid heeft geschaard. Bovendien zijn de eigen cijfers niet achteraf gecorrigeerd wanneer na behandeling dan wel refractiecorrectie de visusvermindering werd gecorrigeerd, c.q. genezen. Toch dient te worden opgemerkt, dat in het eigen onderzoek een aantal gevallen van blindheid/slechtziendheid zijn opgespoord, waarvan de patiënt zich niet bewust was, c.q. waarover deze niet klaagde.

\subsection{Samenvatting en conclusies}

Bij vergelijking van de eigen incidentielijst met die uit de vier andere morbiditeitsregistraties valt als eerste op, dat in het eigen onderzoek een veel meer gedifferentieerde indeling in categorieën van aandoeningen is gehanteerd. Het is zeer goed mogelijk, dat door de anderen wel degelijk meer gedifferentieerd werd gediagnostiseerd, maar dat het gehanteerde registratiesysteem niet de mogelijkheid bood om dit tot uiting te laten komen. Op zich is het echter van betekenis dat in de bestaande registratie-systemen voor het huisartsgeneeskundig handelen de categorie oogheelkunde zo globaal is ingedeeld. Verondersteld mag immers worden dat een dergelijk systeem een afspiegeling vormt van bet handelen van de huisarts.

Naast het feit, dat de eigen registratie meer gedifferentieerd is, valt op, dat een aantal categorieën uit de eigen registratie bij de anderen geheel ontbreken of nauwelijks zijn gevuld. Dit geldt met name voor de categorie fundus-afwijkingen.

Behalve verschil in wijze van registreren bestaan er werschillen in incidenties van een aantal gevonden aandoeningen; met name refractieafwijkingen, cataract, glaucoom en fundusafwijkingen worden in het eigen onderzoek opmerkelijk meer waargenomen. Het corpus alienum daarentegen minder. Gezien de ondervertegenwoordiging van vrouwen boven 65 jaar in de praktijkpopulatie, is er mogelijk nog sprake van een onderschatting van aandoeningen die vooral op die leeftijd voorkomen, zoals cataract, glaucoom en fundusafwijkingen in de eigen registratie.

In hoeverre de wijze van uitvoeren van het oogonderzoek met gebruik maken van de betere apparatuur debet is aan de gevonden verschillen is niet na te gaan. Dat de verschillen hierdoor woor een deel worden verklaard is echter wel aannemelijk. 



\section{Hoofdstuk 8}

\section{VAN KLACHT NAAR DIAGNOSE}

De reden van oogheelkundig onderzoek in relatie tot de diagnose

\subsection{Inleiding}

Hoe de relatie is tussen klacht en diagnose bij de in dit onderzoek geregistreerde consulten komt in dit hoofdstuk aan de orde. De diagnostische betekenis van de klacht wordt geanalyseerd, waarbij de vraag centraal staat: welke diagnosen werden gesteld bij een aantal welomschreven clusters van klachten, bijvoorbeeld: "pijn aan het oog" en "klachten over het zien".

Het waren meestal specifieke oogklachten die voor de arts de aanleiding vormden de ogen van de patiënt na te kijken. Echter, ook vage algemene klachten, zoals hoofdpijn en misselijkheid, werden soms als eerste gepresenteerd bij de geregistreerde consulten. In dergelijke gevallen bood de verdere anamnese aanknopingspunten voor hypothesen betreffende oogaandoeningen. Tenslotte vormden aandoeningen met risico woor het zien zonder oogklachten een indicatie voor oogheelkundig onderzoek.

In de opeenvolgende paragrafen 8.1 en 8.2 komen de diverse redenen voor oogheelkundig onderzoek aan de orde in hun relatie tot de uiteindelijk gestelde diagnose.

De redenen voor oogheelkundig onderzoek zijn onderverdleeld in drie categorieën: specifieke oogklachten (1), vage algemene klachten (2) en aandoeningen met risico voor oogcomplicaties zonder klachten m.b.t. de ogen (3).

De verdeling van de 748 problemen over deze drie categorieën is weergegeven in tabel 8.0.- 1 . 
Tabel 8,0, 1: Reden voor ooghelkandig onderzoek; absolwut en procentucel $(N=751)$.

Absoluut

Procentueel

(1) specifieke oogklachten
(2) vage, algemene klachten
(3) gecn klachter mbit de ogen, well risico

$\begin{array}{rr}580 & 77 \\ 80 & 11 \\ 91 & 12\end{array}$

Totalal

751

100

Uit de tabel valt te lezen, dat in ruim drie kwart van de gevallen het oogonderzoek werd uitgevoerd naar aanleiding van klachten van de patiënt. Bij drie problemen werd blijkbaar meer dan eén reden van oogonderzoek geregistreerd, immers het totaal aan geregistreerde oogproblematiek was 748 .

Nagegaan is, of er duidelijke verschillen bestonden tussen de leeftijdscategorieën en de geslachten ten aanzien van de redenen van oogheelkundig onderzoek.

De indeling van de drie bovengenoemde redenen van oogheelkundig onderzoek naar leeftijd en geslacht van de patiënten wordt in tabel 8.0.- 2 weergegeven.

Tabel 8.0.- 2: $\quad$ Redenen wan oogheelkundig onderzoek $(N=751)$, ingedeeld natar leefijd en geslacht van de patienten; absoluut en als percentage van de betreffende categorie in de totale praktijkpopulatie.

\begin{tabular}{|c|c|c|c|c|c|c|c|c|c|}
\hline & & \multicolumn{4}{|c|}{ Manmen } & \multicolumn{4}{|c|}{ Vrouwen } \\
\hline & & $<25$ & $25-44$ & $45-64$ & $>65$ & $<25$ & $25-44$ & $45-64$ & $>65$ \\
\hline $\begin{array}{l}\text { Specifieke } \\
\text { oogklachten }\end{array}$ & $\%$ & $\begin{array}{r}72 \\
8\end{array}$ & $\begin{array}{r}63 \\
5\end{array}$ & $\begin{array}{l}88 \\
17\end{array}$ & $\begin{array}{l}25 \\
14\end{array}$ & $\begin{array}{l}95 \\
12\end{array}$ & $\begin{array}{l}80 \\
12\end{array}$ & $\begin{array}{l}74 \\
13\end{array}$ & $\begin{array}{l}53 \\
25\end{array}$ \\
\hline $\begin{array}{l}\text { Vage algemene } \\
\text { klaichten }\end{array}$ & $\%$ & $\begin{array}{l}4 \\
\mathbb{1}\end{array}$ & $\begin{array}{r}10 \\
2\end{array}$ & $\begin{array}{r}13 \\
2\end{array}$ & $\begin{array}{l}8 \\
4\end{array}$ & $\begin{array}{l}9 \\
1\end{array}$ & $\begin{array}{r}14 \\
2\end{array}$ & $\begin{array}{r}15 \\
3\end{array}$ & $\begin{array}{l}7 \\
3\end{array}$ \\
\hline $\begin{array}{l}\text { Geen klachten } \\
\text { wel risico }\end{array}$ & $\%$ & $\begin{array}{l}2 \\
0\end{array}$ & $\begin{array}{l}5 \\
1\end{array}$ & $\begin{array}{r}31 \\
6\end{array}$ & $\begin{array}{l}6 \\
3\end{array}$ & $\begin{array}{l}1 \\
0\end{array}$ & $\begin{array}{l}9 \\
1\end{array}$ & $\begin{array}{r}17 \\
3\end{array}$ & $\begin{array}{r}20 \\
9\end{array}$ \\
\hline
\end{tabular}

In hoofdstuk 6 is reeds alangegeven, dat meer vrouwen dan mannen een oogonderzoek ondergingen. Uit tabel 8.0.- 2 blijkt, dat dit verschil met name zit in de presentatie van specifieke oogklachten. Wat betreft de vage algemene klachten en aandoeningen met risico voor het oog zonder klachten zijn de geslachtsverschillen veel minder duidelijk. Met de leeftijd nemen zowel de specifieke oogklachten toe als de aandoeningen waarvoor de arts een oogonderzoek geïndiceerd acht. 


\subsection{Specifieke oogkllachten}

De 580 specifieke oogklachten zijn onder te verdelen in een aantal hoofdgroepen. Tabel 8.1.- 1 geeft hiervan een overzicht. Per groep is het aantal klachten aangegeven, absoluut en als percentage van het totaal aantal specifieke oogklachten.

Tabel 8.1.- 1: $\quad$ Aantal specifieke oogklachten onderverdeeld nadar hoofdgroep; absoluit en procentucel $(N$ $=580$ ).

Absolunt

Klachten over het zien

Pijo aan het oog

Klachten betreffende de oogstand

Klachten over het gezichtsveld

Klachten over de adnexem

Overige oogklachten
247

235

7

2

42

47
Procentueed

42.6

40.5

1.2

0.4

7.2

8.1

Totaal

580

100

Klachten over het zien en pijn aan het oog blijken het overgrote deel van de specifieke oogklachten te vertegenwoordigen. Nagegaan is, of er duidelijke verschillen bestonden tussen de leeftijdscategorieên en de geslachten ten aanzien van de diverse categorieën specifieke oogklachten. Tabel 8.1.- 2 geeft hiervan een overzicht. Klachten over het gezichtsveld en over de oogstand zijn wegens het kleine aantal niet opgenomen.

Tabel 8.1.- 2: $\quad$ Aantal klachten over het zien (1), pijn aan het aog (2), klachten over de adnexen (3) en overige oagklachten (4) ingedeeld naar leeftijal en geslachi; absoluut en als percentage van de betreffende categorie in de torale praktijkpopulatie.

\begin{tabular}{|c|c|c|c|c|c|c|c|c|c|}
\hline & & \multicolumn{4}{|c|}{ Mannen } & \multicolumn{4}{|c|}{ Vrouwen } \\
\hline & & $<25$ & $25-44$ & $45-64$ & $>65$ & $<25$ & $25-44$ & $45-64$ & $>65$ \\
\hline \multirow[t]{2}{*}{ (1) Zien } & & 23 & 15 & 43 & 18 & 19 & 33 & 61 & 35 \\
\hline & $\%$ & 3 & 2 & 8 & 10 & 2 & 5 & 11 & 16 \\
\hline \multirow[t]{2}{*}{ (2) Pijn } & & 34 & 40 & 34 & 3 & 58 & 31 & 25 & 10 \\
\hline & $\%$ & 4 & 6 & 6 & 2 & 7 & 5 & 4 & 5 \\
\hline \multirow[t]{2}{*}{ (3) Adnex } & & 4 & 5 & 8 & 1 & 5 & 7 & 5 & 7 \\
\hline & $\%$ & 0 & 1 & 2 & 1 & 1 & 1 & 1 & 3 \\
\hline \multirow[t]{2}{*}{ (4) Overig } & & 6 & 3 & 3 & 2 & 13 & 7 & 12 & 1 \\
\hline & $\%$ & 1 & 0 & 1 & 1 & 2 & 1 & 2 & 0 \\
\hline
\end{tabular}


Uit tabel 8.1.- 2 blijkt, dat het klagen over het zien toenam met de leeftijd. Het hogere "aanbod" van vrouwen wat betreft specifieke oogklachten komt vooral voor rekening van deze categorie. De andere klachten waren vrij gelijkmatig verdeeld over de verschillende leeftijds- en geslachts-categorieën.

\subsubsection{Nieuw geconstateerde aandoeningen bij klachten betreffende het zien}

Nagegaan is, welke tot dan toe onbekende aandoeningen die als verklaring voor de klacht zouden kunnen dienen, werden aangetroffen bij patiënten die klaagden over het zien. In deze paragraaf wordt daarvan verslag gedaan.

De volgende klachten werden ingedeeld bij de categorie klachten over het zien:

slecht zien veraf, slecht zien dichtbij, geflikker en/of sterretjes zien, mouches volantes zien, draden voor de ogen zien, wazig zien, kringen voor de ogen zien, niet goed zien in het donker, wens toi brilcontrole, bril kapot, refractie-correctie bevalt niet.

De aandoeningen die werden aangetroffen bij diegenen die klaagden over het zien en die als verklaring van de klacht werden beschouwd, zijn weergegeven in tabel 8.1.1.1.

Tabel 8.1.1." 1: Nieuw gewonden aandoeningen bij personen met klachten over het zien $(N=247)$.

Aandoening

Refractieproblemen

Cataract

In geringe mate cataract

Glaswochtmembraanloslating

Verdichte structuur glasvocht

Veel Drusen in macula

Vaatpathologie in fundo

Restgroep retinapathologie

Restgroep

Totalal

potentieel gevaarlijk
Aantal

Refractieafwijkingen ( $74 \%)$ en cataract $(8.5 \%)$ bleken een relatief veel voorkomende bevinding bij klachten over het zien. Alle andere pathologie kwam sporadisch voor, doch is als groep verantwoordelijk voor $17.5 \%$ van de aandoeningen bij klachten over het zien.

De restgroep bestaat uit een aantal aandoeningen die alle én maal werden aangetroffen. Deze staan vermeld in tabel 8.1.1.- 2 . 
Tabel 8.1.1.- 2: Een maal geregistreende aandoeningen bij klachten over het aien.

Aandoening

Strabismus paralyticus
Hordeolum
Blefaritis
Kalk-concrementen
Bacteriele conjunctivitis
Cornea-pigmentaties
Keratitis punctata
Restgroep uvea-afwijkingen
Bloeding pre-retinaal
Fundus thypertonicus graad I en $\mathbb{I I}^{\prime \prime}$
Diabetische retinopathie met bloedingen'
Peripapillaire atrofie
potenticel gevaarlijk

Het totaal aan afwijkende bevindingen als verklaring voor de klacht is 200 . Het total aan klachten betreffende het zien bedroeg echter 247 . De verklaring voor dit verschil is de volgende: enerzijds bevinden zich bij deze 200 geconstateerde afwijkingen dubbeltellingen, met dien verstande dat bij eén en dezelfde persoon meerdere afwijkingen werden geconstateerd. Anderzijds ontbreken in deze opsomming de zogenaamde "negatieve diagnosen", dus die aandoeningen c.q. afwijkende bevindingen, waarnaar gericht werd gezocht, maar die niet werden gevonden (zie voor verdere uitleg Hoofdstuk 5).

De negatieve diagnosen c.q. bevindingen bij klachten over het zien worden weergegeven in tabel 8.1.1.- 3 .

Tabel 8.1.1.- 3: Negarieve bevindingen bij klachten over het zien.

Negatieve bevinding

Aantal

Gave macula

Geen cataract

Geen corneaafwijking

Geen fundus hypertonicus

Geen afwijking van het corpus vitreum

Geen vaatsclerose in fundo

Normale papil

Geen oogstandafwijking

Geen diabetische retinopathie

Waarschijnlijik geen glaucoom

Normale visus; geen refractieafwijking

Totaal

8

7

5

3

3

2

2

1

1

1

43

Uit het bovenstaande kan het volgende worden geconcludeerd: de refractieafwijkingen vormden de grootste categorie van aandoeningen bij klachten over het zien. In $26 \%$ van de gevallen was er echter sprake van een andere aandoening die als oorzaak 
wan de klacht kon worden beschouwd. Het betrof hier in totaal 19 verschillende aandoeningen. Zes gevonden afwijkingen bleken potentieel gevaarlijk. Visusonderzoek alleen, al of niet met refractioneren, zou bij klachten over het zien dus allerminst toereikend zijn geweest.

76 Maal was (een onderdeel wan) het oogonderzoek speciaal gericht op het uitsluiten van een bepaalde aandoening.

\subsubsection{Nieuw geconstateerde aandoeningen bij pijn aan het oog}

Nagegaan is, welke tot dan toe onbekende aandoeningen die als verklaring voor de klacht zouden kunnen dienen, werden aangetroffen bij patiënten die klaagden over pijn aan het oog. In deze paragraaf wordt daarvan verslag gedaan.

De volgende klachten werden ingedeeld bij de categorie pijn aan het oog:

pifn rond/aan/in/achter het oog, rood oog, oogverwonding; chernicaliën in het oog, gevoel of er iets in het oog zit, contacilenzen doen pijn.

In totaal werd 235 maal de klacht pijn aan het oog geregistreerd.

De aandoeningen die werden aangetroffen bij degenen die klaagden over pijn aan het oog en die als verklaring van de klacht werden beschouwd, zijn weergegeven in tabel 8.1.2.- 1 .

Tabel 8.1.2.- 1: Nieuw gevonden aandoeningen bij personen inet klachten over pijn aan het oog $(N=235)$.

Aandoening Aantal

Virale folliculaire conjunctivitis 80

Bacteriale conjunctivitis

Erosio coneae

Keratitis punctata

Corpus alliemum/roestring in corneam

Keratitis marginalis

Hordeolum

Keratoconjunctivitis sicca

Subconjunctivale bloeding

Blefaritis

Trichiasis

Refractieproblemen

Corpus alienum conjunctivae

Acule uveitis anterior

Kalkconcrementen

Pollunosis

Keratitis dendritica

Restgroep cornea-afwijkingen

Restgroep totad

Totaal

potentieel gevaarlijk

De restgroep bestaat uit een aantal aandoeningen die alle é́n maal werden aangetroffen. Deze staan vermeld in tabel 8.1.2.- 2 . 
Tabel 8.1.2. 2: Eën maal geregistreende aandoeningen bij kachten over pijn aan thet oog

Aandoening

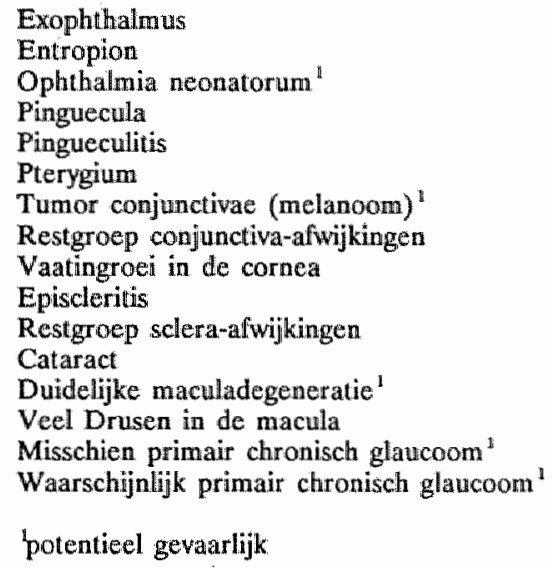

Het totaal aan afwijkende bevindingen als verklaring voor de klacht is 205 . Het totaal aan klachten betreffende pijn aan het oog bedroeg echter 235. De verklaring voor dit verschil is gelijk aan die welke werd gegeven in paragraaf 8.1.1.

De negatieve diagnosen c.q. bevindingen bij klachten over pijn aan het oog worden weergegeven in tabel 8.1.2.- 3 .

Tabel 8.1.2.- 3: Negatieve bevindingen bij pijn aan het oog.

Negatieve bevinding

Aantal

Geen cornea-afwijking

46

Geen conjunctiva-afwijking

35

Geen uwea-afwijking

Geen ooglidafwijking

11

Waarschijnlijk geen primair glaucoom

3

Geen oogstandsafwijking

Geen afwijkingen traanwegen

Normale visus, geen refractieafwijking

Totaal

Uit de tabellen 8.1.2.- 1 en 8.1 .2 - 2 blijkt, dat de meeste aandoeningen het voorste oogsegment betroffen. Slechts 8 aandoeningen vallen hier buiten: refractieproblematiek (4), exophthalmus (1), tekenen van maculadegeneratie (2), glaucoom (2).

De twee vermelde fundusafwijkingen (maculadegeneratie, veel Drusen in macula) zijn in theorie niet pijnlijk. Via welke vertaalslag deze twee patiënten hun ongemak 
in pijn hebben vertaald, is niet duidelijk. Ook pijn ten gevolge van refractieproblematiek ligt niet direkt voor de hand. Uit de literatuur is echter bekend, dat een lang bestaande onvoldoende gecorrigeerde refractieafwijking een chronische conjunctivitis ten gevolge kan hebben. Ook "turen" kan pijnsensaties geven.

Onder de vermelde aandoeningen bevinden zich een tiental (potentieel) ernstige, waarbij tijdige onderkenning en behandeling blijvend verlies van het gezichtsvermogen kan voorkomen.

Onder degenen die klaagden over piin aan het oog bevonden zich ook acht contactlensdragers.

Contactlensdragers met pijn aan het oog vormen een groep met specifieke oogpathologie. Deze groep werd daarom apart geanalyseerd.

In total zeven vrouwen en éen man presenteerden zich met contactlens-problematiek. Onderscheid in harde en zachte contactlenzen werd bij de registratie niet gemaakt. De als oorzaak van de klacht pijn aan het oog geregistreerde aandoeningen waren de volgende:

$3 \times$ conjunctivitis;

$1 \times$ kerato-conjunctivitis, zeer waarschijnlijk t.g.v. een adenovirusinfectie;

$1 \times$ episcleritis;

$1 \times$ keratitis punctata;

$1 \mathrm{x}$ vaatingroei in de cornea;

$1 \mathrm{x}$ oorzaak van de pijn onduidelijk.

De groep van contactlensdragers is te klein om conclusies te trekken ten aanzien van specifieke contactlensproblemen. Wel is duidelijk, dat de huisarts meermalen werd geconsulteerd door contactlensdragers met banale ooginfecties.

Uit het bovenstaande kan het volgende worden geconcludeerd:

Klachten over pijn aan het oog verwezen in verreweg de meeste gevallen naar aandoeningen van het voorste oogsegment. Het scala van aandoeningen, dat hier werd aangetroffen was groot.

28 Verschillende aandoeningen van het voorste oogsegment en vijf andere aandoeningen werden als oorzaak van de klacht pijn aan het oog aangemerkt.

Drie procent van de geconstateerde aandoeningen betrof aandoeningen die blijvend visusverlies tot gevolg hadden kunnen hebben als ze niet tijdig waren onderkend en behandeld.

Wederom is ook het aantal aandoeningen dat werd uitgesloten, groot.

\subsubsection{Nieuw geconstateerde aandoeningen bij klachten betreffende de oogstand}

Nagegaan is, welke tot dan toe onbekende aandoeningen die als verklaring voor de klacht zouden kunnen dienen, werden aangetroffen bij patiënten die klaagden over de oogstand. In deze paragraaf wordt daarvan verslag gedaan.

Scheelzien, dubbelzien en exophthalmus werden ingedeeld bij klachten betreffende de oogstand.

In totaal werd zeven maal én van deze klachten gepresenteerd. Het betrof de volgende gevallen: 
Vier kleuters met scheelzien, waarvan twee wan én jaar en twee van drie jaar. Zij werden verwezen naar de oogarts.

Een vrouw van 29 jaar, die wegens exophthalmus werd verwezen naar de internist; Een jongen van tien jaar die klaagde over dubbelzien, waarbij geen afwijkingen werden gevonden, ook niet in de follow-up periode.

Een vrouw van 62 jaar met klachten over dubbelzien ten gevolge van een slecht gecorrigeerde refractieafwijking van het rechter oog.

Klachten betreffende de oogstand kwamen dus niet veel voor, maar noopten in de meerderheid der gevallen wel tot verdere actie in de zin van verwijzen of beliandelen.

\subsubsection{Nieuw geconstateerde aandoeningen bij klachten betreffende het gezichtsveld}

Deze klacht werd slechts tweemaal geregistreerd. De casuistiek zal daarom in zijn geheel wordlen weergegeven.

1. Een man van 80 jaar werd gezien tijdens een zondagsdienst. Hij vertelde met het rechter oog niet goed te kumnen zien. Bij navraag bleek de uitval het onderste gedeelte van het gezichtsveld te betreffen. Bij oogheelkundig onderzoek werden geen afwijkingen geconstateerd. Dit werd gerapponteerd aan zijn inuisarts. Het vervolg is niet bekend.

2. Bij een vrouw van 33 jaar werden op verzoek van de associé de gezichtswelden onderzocht (perimetrie) wegens haar migraineuze hoofdpijn en haar klacht soms "niets meer te zien". De gezichtsvelden waren nomaal. Zij werd niet verwezen naar de oogarts.

N.B. In de daaropvolgende jaren kwam zij geregeld met dezelfde klachten terug. Vier jaar later volgde verwijzing naar de oogarts. Ook deze kon geen afwijkingen vinden.

Klachten over het gezichtsveld kwamen dus nauwelijks voor, maar gaven wel aanleiding tot het doen van een volledig oogonderzoek.

8.1.5 Nieuw geconstateerde aandoeningen bij klachten betrelfendle de adnexen Nagegaan is, welke tot dan toe onbekende aandoeningen die als verklaring woor de klacht zouden kunnen dienen, werden aangetroffen bij patiënten die klachten hadden met betrekking tot de adnexen. In deze paragraaf wordt daarvan verslag gedaan.

Tot de categorie klachten met betrekking tot de adnexen werden de volgende uitingen gerekend:

al of niet pijnlijk knobbeltje aan oogleden, dikke oogleden, tranerde ogen.

42 personen meldden zich met eén van deze klachten. Nagegaan is, welke nog niet eerder bekende aandoeningen als oorzaak van klachten werden geregistreerd. Deze staan vermeld in tabel 8.1.5.- 1 . 
Tabel 8.15.- 1: Nieume berindingen bif klachten ower de adnexen.

Hordleghinin 14

Dedeem oogleden e.c.i

Challarion

Wratje

Niet aanliggende traanpunten

Resitgroep

De restgroep bestaat uit een aantal aandoeningen die alle én maal werden geregistreerd. Het betreft hier de volgende aandoeningen: blefaritis, herpesinfectie van de oogleden, neurodermitis van de oogleden en pollinosis.

Het totaal aan afwijkende bevindingen als verklaring voor de klacht is 30 , terwijl 42 maal een klacht met betrekking tot de adnexen werd gepresenteerd. De verklaring voor dit verschil is gelijk aan die, welke is gegeven in de paragrafen 8.1.1 en 8.1.2.

De negatieve diagnosen worden weergegeven in tabel 8.1.5.- 2.

Tabel 8.1.5. 2: Negatieve bevindingen bij klachten ower de adnexen; gerich gezocht maar niet gewonden.

Bievinding

Aantal

Geen afwijkingen traanwegen

Geen afwijkingen conjunctivae

Geen ooglidafwijkingen

9

4

2

Totall

15

Uit het bovenstaande kan het volgende worden geconcludeerd:

Bij klachten over de adnexen was de localisatie van de pathologie bijna altijd gerelateerd aan de inhoud van de klacht; bijwoorbeeld klachten over een pijnlijk klein gezwel aan de oogleden betrof meestal een hordeolum, tranende ogen verwezen naar het traanafvoersysteem. Met andere woorden: de diagnostiek leverde weinig problemen op. Een volledig oogonderzoek was zelden noodzakelijk. Onderzoek van het voorste oogsegment leverde echter wel een aantal afwijkingen op.

\subsubsection{Nieuw geconstateerde aandoeningen bij overige oogklachten}

Nagegaan is, welke tot dan toe onbekende aandoeningen die als verklaring voor de klacht zouden kunnen dienen, werden aangetroffen bij patiënten met "overige oogklachten". In deze paragraaf wordt daarvan verslag gedaan.

De volgende klachten werden ingedeeld bij "overige oogklachten": 
jeuk aan de ogen, ogen 's morgens dichtgeplakt, droge ogen, wermoeid gevoel achter/ in de ogen, patiënt meent om wat voor reden dan ook zijn ogen te moeten laten nakijken.

In totaal werd 47 maal een klacht gepresenteerd, vallend binnen deze categorie.

De ter verklaring van deze oogklachten nieuw geconstateerde aandoeningen werden geïnventariseerd en staan vermeld in tabel 8.1.6.- 1.

Tabel 8.1.6.- 1: Nieuwe ontdekte aandoeningen ter verklaring van "overige oogkJachten".

Aandoeming

Aantal

Neurodermitis oogleden

Virale conjunctivitis

Blefaritis

Keratitis marginalis

Bacterielle conjunctivitis

Restgroep

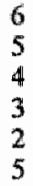

Totaal

25

De restgroep bestaat uit een aantal aandoeningen die alle éen maal werden geregistreerd. Het betreft hier de volgende aandoeningen: stenosis van de traanwegen, verminderde traanproductie, sub-conjunctivale bloeding, pollinosis, een tumor in de conjunctiva.

Het totaal aan afwijkende bevindingen als verklaring voor de klacht (25) wijkt wederom af van het totaal aantal maal, dat een klacht in deze categorie werd gepresenteerd (47). De verklaring voor dit verschil is dezelfde als vermeld in paragraaf 8.1.1, 8.1.2 en 8.1.5.

De negatieve diagnosen/bevindingen worden weergegeven in tabel 8.1.6.- 2 .

Tabel 8.1.6.- 2: Negatiene bevindingen bij owerige oogklachten.

Bevinding

Aandal

Geen afwijkingen conjunctiva

Geen primaï chronisch glaticoom

Geen ooglidafwijking

Geen afwijkingen traanwegen

Geen cornea-afwijking

8

3

1

1

1

Totaal

Uit het bovenstaande kan het volgende worden geconcludeerd: 
Oogziekten die werden gevonden bij "overige oogklachten" waren voornamelijk gelokaliseerd in de oogleden. Drie maal werden echter cornea-afwijkingen aangetroffen. Fundusafwijkingen kwamen niet voor.

\subsubsection{Conclusies}

De specifieke oogklachten die gedurende anderhalf jaar aan de huisarts werden gepresenteerd zijn van velerlei aard, doch betreffen voor het merendeel "minder goed zien" en "pijn aan het oog". De bij deze klachten geconstateerde aandoeningen representeren een weids spectrum van oogaandoeningen. Anders gezegd, de klacht verwees niet duidelijk naar ến bepaalde groep van aandoeningen, waarop men het onderzoek specifiek zou kunnen richten. Bij pijn aan het oog werden zelfs aandoeningen als refractie-anomalie en macula-degeneratie als verklaring voor de klacht aangemerkt.

Toch gaf de klacht wel enige indicatie woor de localisatie van de aandoening. Klachten over het zien werden in de meerderheid der gevallen veroorzaakt door een refractieafwijking. Pijn aan het oog verwees in de meerderheid der gevallen naar een aandoening van het voorste oogsegment. Bij klachten over de adnexen waren alle geconstateerde aandoeningen in de adnexen gelokaliseerd.

De meeste aandoeningen waren onschuldig van aard met dien verstande, dat bij niet onderkennen geen gevaar bestond voor verlies van het gezichtsvermogen. Bij in totaal 20 aandoeningen (inclusief strabismus) was dit echter wel het geval.

Opvallend vaak was (een deel van) het oogonderzoek gericht op het uitsluiten van een bepaalde aandoening en werd als diagnose een zogenaamde "negatieve diagnose" gesteld.

\subsection{Bevindingen bij surveillerend oogonderzoek}

In het eerste gedeelte van dit hoofdstuk (8.1) werden de aandoeningen vermeld die als verklaring konden dienen van een specifieke klacht van de patiënt met betrekking tot de ogen, dan wel het zien.

In nu volgende gedeelte (8.2) zal het accent liggen op de bevindingen bij "surveillerend" oogonderzoek, waarmee bedoeld wordt, onderzoek dat de arts op eigen initiatief verricht omdat:

- deze de mogelijkheid aanwezig acht, dat er sprake is van nog een andere oogaandoening dan die waarop de specifieke oogklacht van de patiënt betrekking heeft.

- de patiënt vage algemene klachten heeft, waarbij de arts een oogaandoening als mogelijke oorzaak van de klacht overweegt.

- de patiënt lijdt aan een aandoening, waarbij oogcomplicaties kunnen optreden, zonder dat sprake is van klachten betreffende de ogen c.q. het zien.

Bewust wordt niet gesproken van toevalsbevindingen. Het gaat hier namelijk steeds om bevindingen waarnaar gericht is gezocht, b.v. glaucoom bij iemand ouder dan 40 jaar, microaneurysmata bij een diabetes-patiënt.

In de navolgende paragrafen zullen de bevindingen bij surveillerend onderzoek, behorende bij de hierboven genoemde indicaties, achtereenvolgens worden besproken. 
Tabel 8.1.- 1: Positieve bevindingen bij surveillerend oogondenoek bij patienten mut spechfieke oogklachten.

Bevinding

Aantal

Refractieafwijking

$2^{l}$

Hordeolum

1

Pingueculum

2

Pterygium

Corneapigmentaties

2

Gering cataract

18

Duidelijk cataract

Glasvochtmembraanloslating

3

Meer dan normale troebelingen corpus vitreum

Sinchisis scimtillans

Persisterende arteria hyaloidea

Oude chorioretinitis

Nauwe arteriolen/wijde venen bij hypertensio

Bloedingen in fundo bij hypertensie

Diabetische retinopathie met minstens ên microaneurisma

Arterioloselerose graad 1

Venetakthrombose

Pigmentafwijkingen in de macula

Drusen in de macula

Papiloedeem

Peripapillaire atrofie

C/D verdacht woor glaucoom

Misschien glaucoom.

Waarschijnlijk glaucoom

tmedisch ingrijpen dan wel verwijzen lijkt wenselijk

potentieel gevaarlijk

\subsubsection{Nieuw geconstateerde aandoeningen bij surveillerend onderzoek bïj patienten met specifieke oogklachten}

Hoe vaak een deel van het oogonderzoek bij mensen met specifieke oogklachten ten behoeve van surveillance is uitgevoerd, is niet bekend.

De positieve bevindingen worden vermeld in tabel 8.2.1.- 1. De bevindingen worden gepresenteerd in de volgorde die correspondeert met de volgorde van handelingen zoals die wordt aangehouden bij het routine oogonderzoek. Dat wil zeggen, onderzoek naar: refractieafwijkingen, aandoeningen van het voorste oogsegment, fundusafwijkingen en afwijkende oogdruk.

Bevindingen, die duiden op gevaar voor het gezichtsvermogen en bevindingen waarbij medisch ingrijpen dan wel verwijzen wenselijk lijkt, worden apart aangegeven.

Uit tabel 8.2.1.- 1 komt een opvallend verschil in klinische importantie naar voren van de bevindingen betreffende het voorste oogsegment enerzijds, en de bevindingen betreffende de fundus en de oogdruk anderzijds. De bevindingen van het voorste oogsegment zijn alle van geringe ernst. 
Tabel 8.2.2.- 1: Nieuw geconstateedo adndoeningen bij wage afgemene klachen.

Bevinding

Aantal

Refractieproblemen

Virale conjunctivitis

Restgroep corntea-afwijkingen

Restgroep sclera-afwijkingen

Gering cataract

Duidelijilk cataract

Sinchisis scintullans

Nauwe arteriolen, wijde venen bij hypertensie

Bloedingen in fundo bij hypertersice.

Fundus arteriolosclerose graad 1

Venetakthrombose

Andere vastpathologie in fundo

Drusen in de macula

Papiloedeem

C/D verhoudingen verdacht woor glaucoom

Misschien gllaucoom

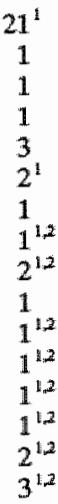

Totalal

43

medisch ingrüjpen dan wel verwijzen lijkt wenselijk

potenticel gevaarlijk

Heel anders ligt dat voor de bevindingen, aangetroffen bij funduscopie en oogdrukmeting. Hier is in het merendeel van de gevallen sprake van afwijkingen die op den duur het gezichtvermogen kunnen aantasten.

De bevindingen waarbij medisch ingrijpen dan wel verwijzen wenselijk lijkt, vormen samen $68 \%$ van het totale aantal.

De macula-afwijkingen vormen in zoverre een uitzondering, dat hierbij medisch ingrijpen weinig zinvol is, maar dat surveillance door de oogarts wel is aan te bevelen, on de progressie nauwlettend te volgen.

De bevindingen die (bovendien) gevaar opleveren voor het gezichtsvermogen, maken $57 \%$ van bet totaal uit.

Uit bovenstaande kan men concluderen, dat bij surveillerend oogonderzoek, dat verricht werd bij patiënten met een specifieke oogklacht, een weids scala van bevindingen c.q. aandoeningen werd aangetroffen, waarvan het merendeel als potentieel schadelijk voor het gezichtsvermogen kan worden beschouwd.

\subsubsection{Nieuwe bevindingen bij vage algemene klachten}

Nagegaan is, welke bevindingen werden aangetroffen bij volledig oogonderzoek, dat verricht werd op initiatief van de arts bij patiënten die zich presenteerden met vage 
algemene klachten. Zoals reeds opgemerkt, vormde de verdere anamnese een indicatie tot het verrichten van een oogheelkundig onderzoek.

De volgende klachten werden ingedeeld bij vage algemene klachten:

moeheid, hoofdpijn, misselijkheid, duizeligheid, algemene malaise.

In totaal werd 80 maal bij deze klachten een volledig oogonderzoek verricht. Hoewed mensen zich in de registratieperiode in totaal met vage algemene klachten op het spreekuur presenteerden is niet bekend. Dit is zeker een veelvoud van het hier vermelde aantal. In de meeste gevallen zag de arts geen noodzaak tot het verrichten van een oogonderzoek, hetzij, omdat een aandoening buiten het oog, dan wel geen organische aandoening, meer voor de hand lag, hetzij, omdat een oogaandoening in het geheel niet waarschijnlijk werd geacht.

De nieuwe bevindingen van het oogonderzoek bij wage algemene klachten zijn vermeld in tabe] 8.2.2.- 1 . De bevindingen worden gepresenteerd in de volgorde die correspondeert met de volgorde van handelingen zoals die plaatsvinden bij een routine oogonderzoek, zoals beschreven in paragraaf 8.2.1.

Bevindingen, waarbij medisch ingrijpen dan wel verwijzen wenselijk lijkt, en de bevindingen die duiden op gevaar voor het gezichtsvermogen, zijn apart aangegeven.

Uit de tabel blijkt, dat met name te voren niet bekende refractieafwijkingen aan het licht kwamen. De aangetroffen fundusafwijkingen zijn wederom van nogal ernstige aard.

Het totaal aan bevindingen, waarbij medisch ingrijpen dan wel verwijzen wenselijk lijkt bedraagt ruim driekwart van thet totale aantal. De aandoeningen, die (bovendien) een potentieel gevaar voor het gezichtsvermogen inhouden, beslaan een kwart van het totaal.

Uit het bovenstaande kan geconcludeerd worden, dat bij het vermoeden van een oogaandoening als oorzaak van een vage algemene klacht, oogaandoeningen van diverse aard werden aangetroffen, waarvan refractieafwijkingen en fundusafwijkingen het overgrote deel uitmaakten. Ruim een kwart van de aangetroffen bevindingen hielden een potentieel gevaar voor het gezichtsvermogen in.

\subsubsection{Oogonderzoek bij aandoeningen met mogelijke oogcomplicaties}

Bij een aantal (systeem-)aandoeningen kan ook het oog worden aangedaan. Het meest bekend zijn diabetes en hypertensie. Diabetische retinopathie is zelfs de belangrijkste oorzaak van blindheid in de westerse wereld. Bij patienten met dergelijke aandoeningen is het derhalve van belang regelmatig oogonderzoek te verrichten, om vroegtijdig oogcomplicaties op te sporen en daarmee mogelijk verlies van gezichtsvermogen te voorkomen.

In de eigen praktijk wordt één maal per maand een spreekuur voor type II-diabeten gehouden. Elke type II-diabeet wordt minstens een maal per jaar oogheelkundig nagekeken. Bij oogklachten of geconstateercle verontrustende bevindingen vaker.

Niet alle diabeten uit de praktijk bezoeken het spreekuur. Sommigen zijn onder behandeling van internist en oogarts. Deze patiënten komen in dit onderzoek niet 
yoor, waar het gaat om surveillance in het kader van hun diabetes. Mogelijk wel, indien zij zich met specifieke oogklachten of vage algemene klachten op het spreekuur presenteerden.

De hypertensie-patiënten worden in de eigen praktijk NIET systematisch oogheelkundig onderzocht. De indicatie tot oog-onderzoek is afhankelijk van de hoogte van de bloeddruk, andere risicofactoren enz.

Een derde groep betreft patiënten met een cardiovasculair lijden. Ook zij worden op geleide van de ernst van hun aandoening en bijkomende risicofactoren meer of minder frequent oogheelkundig onderzocht.

In total werden 88 patiënten met aandoeningen met mogelijke oogcomplicaties gezien.

In tabel 8.2.3. - 1 worden alle nieuwe bevindingen vermeld, die geconstateerd werden bij surveillerend oogonderzoek bij patienten met een dergelijke aandoening.

Tabel 8.2.3.- 1. Nieuwe bevindingen bij survillerest oogonderzoek bij patienten met aandoeningen met magelijke oogcomplicaties.

Refractieproblemen

Corneapigmentaties

Restgroep cormea-afwijkingen

Gering cataract

Duidelijk cataract

Glasvochtmembraanloslating

Verdichte structuur gllasvocht

Persisterende arteria hyaloidea

Oude chorioretinitis

Nauwe arteriolen/wijde venen bij hypertensic

Bloedingen in fundo bij hypertensic

Bloedingen en cottonwools bij hypertensie

Minstens eén microaneurysma bili diabetes.

Bloedingen en exsudaten bij diabetes

Arteriolosclerose graad 1

Arteriolosclerose graad 2

Zilverdraadarteriolen

Venertakthrombose

Andere watafwijkingen in fundo

Geringe pigmentafwijkingen in macula

Veel Drusen in macula

Peripapillaire atrofie

Misschien glaucoom

medisch ingrijpen dan wel verwijzen lijkt wenselijk

potenticel gevararitijk

$\mathrm{Bij}$ de presentatie van de bevindingen wordt weer de volgorde van een routineoogonderzoek aangehouden, zoals vermeld in paragraaf 8.2.1. 
Bevindingen, waarbij medisch ingrijpen dan wel verwijzen wenselijk lijkt, en bevindingen die duiden op gevaar voor het gezichtsvermogen, zijn apart aangegeven.

Zoals te verwachten was bij een groep die voornamelijk bestaat uit diabeten, en patiënten met hypertensie en cardiovasculair lijden, werden voornamelijk fundusafwijkingen gevonden. De aandoeningen waarbij medisch ingrijpen dan wel verwijzen wenselijk lijkt, maken $65 \%$ van het totaal aantal bevindingen uit.

De aandoeningen die bovendien potentieel gevaar opleveren voor het gezichtsvermogen vormen $53 \%$ van het totaal.

\subsubsection{Conclusies}

Geconcludeerd kan worden, dat surveillerend oogonderzoek werd uitgevoerd bij een groot aantal personen. Bij vage algemene klachten en bij aandoeningen met mogelijke oogcomplicaties alleen al werd 168 mal het oog volledig nagekeken. De aard van de daarbij geconstateerde bevindingen is veelbetekenend. Een groot aantal fundusafwijkingen van vrij ernstige aard werd ontdekt. Bij vage klachten tevens een aanzienlijk aantal tevoren niet bekende refractieafwijkingen.

\subsection{Beschouwing}

In dit hoofdstuk is weergegeven, wat het oogonderzoek dat gedurende anderhalf jaar in totaal 910 maal werd verricht, aan nieuwe bevindingen heeft opgeleverd.

Daaruit blijkt, dat de bevindingen een weids spectrum van oogheelkundige aandoeningen representeren. Opmerkelijk is, dat de bevindingen bij surveillerend onderzoek qua ernst de bevindingen resulterend uit oogonderzoek naar aanleiding van specifieke oogklachten overtreffen. Dit is niet zo verwonderlijk, indien men bedenkt, dat een aantal ernstige oogaandoeningen pas in een laat stadium klachten veroorzaken, zoals primair chronisch glaucoom en een groot deel van de funduspathologie. Tijdig ingrijpen $\mathrm{kan}$ in veel gevallen blijvende schade aan het gezichtsvermogen voorkomen.

Het lijkt dus alleszins de moeite waard om oogproblematiek in de eerste lijn ook anticiperend te benaderen. Daarmee zal zeker worden bijgedragen aan de preventie van verlies van gezichtsvermogen.

In hoofdstuk 10 zullen de potentieel gevaarlijke aandoeningen opnieuw aan de orde komen. Het verschil tussen de opbrengst naar aanleiding van specifieke oogklachten en de opbrengst naar aanleiding van surveillance wordt daar, nu vanuit de optiek van preventie, nogmaals besproken. 



\section{Hoofdstuk 9}

\section{TUSSEN KLACHT EN BEVINDING}

Instrumentele voorwaarden voor oogdiagnostiek

\subsection{Inleiding}

Om aan te tonen, dat een bepaald instrument noodzakelijk is om een bepaalde diagnose te stellen, zou een vergelijking moeten worden gemaakt tussen de beoordeling van een oogheelkundig probleem door een groep artsen zonder en een groep artsen mét dat instrument.

Daar een dergelijke opzet niet haalbaar was, moest hier worden volstaan met een "indirekte" bewijsvoering voor de zinvolheid van het instrumentele diagnostische handelen, afgeleid uit de verzamelde gegevens ten aanzien van de relatie tussen klacht, hulpmiddel en diagnose. In dit hoofdstuk wordt hierop nader ingegaan.

De opbouw van dit hoofdstuk is als volgt:

In paragraaf 9.1 zal worden aangegeven, welke hulpmiddelen in de eigen praktijk op bruikbaarheid voor de huisarts werden getoetst en welke gedurende de onderzoeksperiode werden aangewend.

In paragraaf 9.2 worden de acht meest gebruikt hulpmiddelen in relatie tot de oogklacht van de patiënt besproken.

In paragraaf 9.3 wordt het gebruik van de spleetlamp in relatie tot de diagnostiek van het voorste oogsegment belicht.

In paragraaf 9.4 zullen de ophthalmoscopische mogelijkheden van de indirecte funduscoop worden gedemonstreerd aan de hand van de opbrengst aan diagnosen.

Paragraaf 9.5 schetst de mogelijkheden voor glaucoom-diagnostiek in de huisartspraktijk met behulp van de applanatietonometer.

\subsection{De hulpmiddelen}

Sinds 1977 zijn in de praktijk van de onderzoeker een aantal hulpmiddelen aangeschaft dan wel op proef gevraagd. Doel was te achterhalen, welke set van instrumenten noodzakelijk en voldoende zou zijn, om oogheelkundige problemen in de praktijk snel en effectief te kunnen benaderen. De instrumenten werden "getest" op grond van de 
volgende criteria: praktische hanteerbaarheid, de kwaliteit van de verkregen informatie, prijs en vereiste studie-inspanning. Uiteraard was de uit deze "testprocedure" resulterende keuze een persoonlijke keuze. Dat neemt niet weg, dat hiermede wordt aangegeven, dat voorafgaand aan het onderzoek ervaring is opgedaan met een ruim assortiment aan instrumentarium. Het voor de huisartspraktijk geschikt geachte pakket aan hulpmiddelen representeert anno 1989 een bedrag van f. 8000,-. Indien dit wordt afgezet tegen de prijs van het doorgaans aanwezige instrumentarium, bestaande uit visuskaart, brilloep, Schiötz-tonometer of Glaucotest en direkte fundoscoop, geschat rond 4.500 .- betekent dit een extra investering.

Tabel 9.1.- 1 geeft de beproefde instrumenten/hulpmiddelen aan. Met "*" zijn de instrumenten/hulpmiddelen aangegeven, die geschikt werden geacht woor gebruik in de huisartspraktijk.

Tabel 9.1.- 1: Op bruikbaariteid onderzochte instrumenten/hulpmiddelen.

" visuskaart veraf; verschillende uitvoeringen

* visuskaart dichtbij

- focale belichting met brilloep: verschillende modellen

- splectlamp vergroting $10 \times, 16 \mathrm{x}_{\mathrm{i}} 25 \mathrm{x}, 40 \mathrm{x}$.

* directe funduscoop; verschillende uitvoeringen

* indirecte funduscoop; verschillende uitvoeringen cornet-contactglas.

retinacamera.

Glaucotest.

* applanatietonometer.

* fluoresceîne.

* Bengaals rood.

* Schirmertest.

* proef van Anel.

* centraal gezichtsveldtest volgens Amsler.

* brillendoos. topsterktemeter. perimeter...

* klleurentest van Ishihara.

* test op dieptezicn.

* door de onderzoeker geschikt geacht woor de huisartspraktijk

Omdat met de perimeter nog weinig ervaring was opgedaan, is dit instrument wel in de registratieperiode gebruikt en ook geregistreerd.

\subsubsection{De in het onderzoek betrokken hulpmiddelen}

Het aantal malen, dat de verkozen instrumenten tijdens de registratieperiode werden gebruikt, wordt weergegeven in tabel 9.1.2.- 1 .

Uit de tabel blijkt, dat de spleetlamp, de applanatie-tonometer, de indirecte funduscoop en de visuskaart voor veraf en dichtbij zeer vaak werden gebruikt. Geen enkele keer werd gebruik gemaakt van Bengaals rood en van de directe funduscoop. Ten aanzien van Bengaals rood geldt, dat dit doorgaans in deze praktijk wordt gebruikt bij een verdenking op keratitis dendritica, als deze niet met 
fluoresceïne kan worden aangetoond. Deze situatie heeft zich in de registratieperiode blijkbaar niet voorgedaan. De direkte fundoscoop werd niet gebruikt, ondat de onderzoekend arts in alle gevallen meende te kunnen volstaan met onderzoek via de indirekte fundoscoop.

Tabel 9.1.2.- 1: Frequente wan gebnik van de verschillende mulpmiddelen, absolwat en als pencentage van het total aantal oogproblemen $(N=748)$.

\begin{tabular}{lcc} 
Hulpmiddel & Absoluut & Procentu \\
\hline spleetlamp & & \\
indirecte funduscoop & 473 & 63.2 \\
visuskaart veraf & 362 & 48.4 \\
applanatietonometer & 359 & 48.0 \\
leeskaart dichtbij & 244 & 32.6 \\
fluoresceine & 155 & 20.7 \\
focale bellichting + brillocp & 57 & 8.0 \\
brillendoos & 43 & 5.0 \\
perimeter & 27 & 4.0 \\
Schirmertest & 13 & 1.0 \\
proef van Anel & 8 & 1.0 \\
ander hulpmiddel & 8 & 1.0 \\
Amsler & 3 & 0.4 \\
Bengaals rood & 2 & 0.3 \\
directe funduscoop & 0 & - \\
& 0 & -
\end{tabular}

N.B. Ondler "ander hulpmiddel" wordt verstaan het gebruik van de kleurentest van Ishihara en de dieptezien-test.

\subsection{De relatie tussen kJacht en hulpmiddel}

In deze paragraaf komt het gebruik van het hulpmiddel in relatie tot de oogklacht aan de orde. Alleen de acht meest gebruikte hulpmiddelen worden besproken, te weten de spleetlamp, de indirecte funduscoop, de visuskaart veraf, de leeskaart, de applanatietonometer, de fluoresceine-kleuring, de focale belichting met brilloep en de brillendoos.

De oogklachten werden onderverdeeld in dezelfde categorieën als gehanteerd in hoofdstuk 8. Het gebruik van hulpmiddelen werd niet onderzocht in relatie tot klachten over standsafwijkingen, klachten betreffende het gezichtsveld en "overige oogklachten". De aantallen oogproblemen binnen de eerste twee categorien waren te gering, en de "overige oogklachten" waren te slecht omschreven om enige betekenis toe te kennen aan de uitkomsten.

In tabel 9.2.- 1 wordt weergegeven hoe vaak (in percentages) binnen een bepaallde klachtencategorie van een bepaald hulpmiddel gebruik werd gemaakt.

Uit de tabel blijkt dat bij klachten betreffende het zien in de meeste gevallen een bijna volledig oogonderzoek werd uitgevoerd. Bij "geen oogklachten" werd bijna altijd gebruik gemaakt van de indirekte fundoscoop en dikwijls ook van de andere 
hulpmiddelen. Bij pijnklachten en adnexklachten werd in veel gevallen volstaan met alleen het gebruik van een spleetlamp.

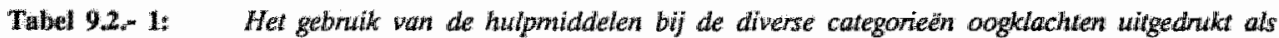

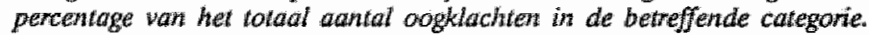

\begin{tabular}{|c|c|c|c|c|}
\hline s & $\underset{(n=247)}{\text { Zien }}$ & $\begin{array}{c}\text { Pijn } \\
(\mathrm{n}=235)\end{array}$ & $\begin{array}{l}\text { Adnexen } \\
(n=42)\end{array}$ & $\begin{array}{c}\text { Geen } \\
\text { oogkllachten }{ }^{1} \\
(\mathrm{n}=168)\end{array}$ \\
\hline spleedlamp & 69 & 81 & 36 & 42 \\
\hline indirekte funduscoop & 77 & 9 & 2 & 84 \\
\hline wisuskatart veraf & 91 & 17 & 14 & 42 \\
\hline applanatietonometer & 60 & 9.8 & 4.3 & 35 \\
\hline leeskaart dichtbij & 48 & 3 & 42 & 13 \\
\hline fluoresceine & 0.4 & 23 & - & . \\
\hline focale bel. + brilloep & 0.4 & 8.5 & 29 & 0.6 \\
\hline brillendoos & 5.3 & 0.8 & 2.3 & 6.0 \\
\hline
\end{tabular}

betreft de categorieển: vage algemene klachten en aundoeningen met mogelijke cogcomplicaties.

\subsection{De relatie tussen het gebruik van de spleetlamp en de diagnose}

Gebruik werd gemaakt van een spleetlamp, gemonteerd op een in hoogte verstelbaar tafeltje. Onderzocht werd steeds met een vergroting van 16 maal.

Voor de noodzaak wan het gebruik van de spleetlamp ontbreken in dit onderzoek direkte empirische bewijzen. Wel kan het belang van het gebruik van de spleetlamp aannemelijk worden gemaakt door na te gaan, welke categorieën van aandoeningen met de spleetlamp werden gediagnostiseerd, die met een apparaat met een minder sterk optisch onderscheidend vermogen redelijkerwijs niet zouden zijn ontdekt.

Om dit na te gaan, zijn de bevindingen onderverdeeld in de volgende categorieën:

1. Aandoeningen met kans op blijvende schade ten aanzien van het gezichtsvermogen.

2. Onaangename (maar niet gevaarlijke) aandoeningen. (Het aantonen hiervan is vooral belangrijk met betrekking tot de therapie)

3. Self-limiting diseases, of (betrekkelijk) onschuldige aandoeningen. (Het aantonen hiervan is vooral belangrijk, omdat dan niet verder gezocht behoeft te worden naar een andere verklaring van de klacht).

4. Geen afwijkingen. (een konsekwente voortgang van het diagnostisch proces veronderstelt vaak de noodzaak on bepaalde ziekten uit te sluiten).

5. Afwijkingen, die informatie geven over de algemene gezondheidstoestand van de patient (categorie: "informatief").

Deze indeling is toegepast op de twee grootste klachten-categorieën, namelijk klachten over het zien en klachten over pijn aan het oog.

Aandoeningen watrvan mag worden aangenomen dat ze zonder spleetlamp niet zouden zijn ontdekt, zijn "gemerkt". 


\subsubsection{Het gebruik van de spleetlamp in relatie tot klachten over het zien}

In tabel 9.3.1.- 1 worden de met de spleetlamp gediagnostiseerde aandoeningen weergegeven bij klachten over het zien. Hierbij werd in 170 van de 247 gevallen gebruik gemaakt van de spleetlamp.

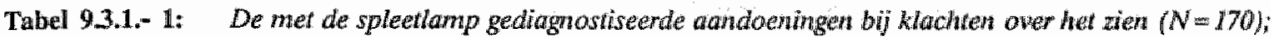
absolute aamallen.

Categorite

Potentiel gevaarlijk

Onaangenaam

Negatiewe diagnostiek

Informatief t.a.\%. de algemene gezondheidstoestand.
Aandoening

Antal

0

blefaritis

kalkconcrementen $\mathrm{i} / \mathrm{d}$ conjunctiva

keratitis punctata

gering cataract

cataract

0

13

1

1

$14^{1}$

26

hordeolum

bacterielle conjunctivitis

pinguecula

pterygium

corneapigmentaties

glasvochtmembraanloslating

troebelingen corpus vitreum

sinchisis scintillans

2

1

2

3

2

$7^{11}$

$2^{4}$

$2^{11}$

geen cornea-afwijking

geen cataract

geen afwijking corpus vitreum

$10^{1}$

$94^{1}$

$3^{\prime \prime}$

0

Totaal

Niet te zien zonder spleetlamp.

Het totaal is meer dan 170 omdat bij sommigen meer dan én bevinding werd gedaan, b.v. kalkconcrementen in de conjunctiva én géén cataract.

Blijkens deze tabel werden tijdens de registratieperiode bij de personen met klachten over het zien met behulp van de spleetlamp geen potentieel gevaarlijke aandoeningen ontdekt.

Opvallend vaak werd "géén cataract" geconstateerd. Bij personen boven 50 jaar met klachten over het zien moest vaak een cataract als verklaring van de klacht worden uitgesloten.

9.3.2 Het gebruik van de splleetlamp in relatie tot klachten over pijn aan het $00 \mathrm{~g}$ In tabel 9.3.2.- 2 worden de met de spleetlamp gediagnostiseerde aandoeningen weergegeven bij klachten over pijn aan het oog. Bij de 235 patienten met klachten over pijn aan het oog werd 190 maal gebruik gemaakt van de spleetlamp. 
Tabel 932. 2: De net de spleetlanp gediagnowiserde adndoeningen bij klachten over pijn aan het oog $\left(N^{*}=190\right) ;$ absolute abmallen.

Categorie

Gevalarlijk

Onaangenaam

Self-limiting/onschuldig

Negatiewe diagnosen

Informatief ta.v. de algemene gezondheidstoestand.
Aandoening

Aantal

$\begin{array}{lc}\text { entropion } & 1 \\ \text { humor vatn de conjunctiva } & 1 \\ \text { keratitis dendritica } & 2^{\mathrm{b}} \\ \text { corpus alienum/roestring in de cornea } & 10 \\ \text { acute weitis } & 3^{\mathrm{t}}\end{array}$

blefaritis 4

verminderde traamproductie 5

corpus alienum in de conjunctiva 3

pingueculitis $\quad 1$

keratitis electrica 2

erosie 14

episcleritis 1

kalkconerementen $\quad 3$

trichüasis 5

keratitis marginalis $10^{4}$

keratitis punctatit $\quad 12^{\mathrm{t}}$

vatingroei cormea $1^{1}$

hordeolum 7

bacteriele conjunctivitis $\quad 19$

virale conjunctivitis $\quad 80$

pinguecula 1

pterygium 1

hooikoorts 2

geen ooglidafwijkingen

geen afwijkingen traanwegen

geen conjunctiva-afwijkingen $21^{\prime}$

geringe conjunctiva-afwijkingen $17^{\prime}$

geen cornea-alwijkingen $56^{\prime}$

geen afwijkingen in de voorste aogkamer $13^{b}$

0

300

(1)

Totaal

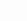

hist te zien zonder spleetlanp

Het totaal is meer dan 190 omdat bij sommige patienten meer dan éen diagnose werd gesteld, b.v. wel virale conjunctivitis, geén corneaafwijkingen, geen afwijkingen voorste oogkamer.

Bij het pijnlijke rode oog zouden zonder spleetlamp zeer waarschijnlijk de beginverschijnsdelen van herpes-ooginfecties (2) en van de acute iritis (3) gemist zijn. Bovendien zou de behandeling van een roestring in de cornea (10) mogelijk problemen hebben opgeleverd. 
Bij de groep "onaangenaam" werden 31 afwijkingen genoteerd, welke zonder hulp van een spleetlamp door mij niet zouden zijn gezien.

In totaal werd 163 maal, dus in ongeveer de helft van de gevallen, een diagnose gesteld waarvoor het gebruik van een spleetlamp noodzakelijk mag worden geacht, hetgeen in dit geval het volgende inhoudt:

- zonder spleetlamp zouden vijf ernstige aandoeningen zijn gemist.

- zonder spleetlamp zouden 31 onaangename aandoeningen zijn gemist.

- zonder spleetlamp zou de diagnostische voortgang zijn geblokkeerd, doordat men 107 maal niet in staat was geweest aandoeningen van conjunctiva, cornea en voorste oogkamer uit te sluiten.

\subsection{De relatie tussen het gebruik van de indirekte fundoscoop en de diagnose}

De oogfundus kan alleen worden bekeken met een funduscoop. Het is derlaalve uitgesloten, dat fundusafwijkingen zouden zijn ontdekt zonder funduscoop.

Er werd uitsluitend gewerkt met de indirekte fundoscoop, aangesloten op een koude lichtbron en met een lens met een vergroting van 20 maal.

Aangezien de negatieve fundusbevindingen niet systematisch werden geregistreerd, kunnen deze niet worden vermeld. De negatieve bevindingen werden namelijk afhankelijk van de klinische vraagstelling de ene keer als

"geen fundus hypertonicus", of de andere keer als "gave macula", of weer een andere keer zeer in het algemeen als "geen fundusafwijkingen" geregistreerd.

Tabel 9.4.- 1 geeft een overzicht van de nieuw gevonden fundus-pathologie bij diegenen, die ophthalmoscopisch werden onderzocht. Voor de diagnostiek van de 748 geregistreerde oogproblemen werd 362 maal gebruik gemaakt van de indirecte funduscoop.

Tabel 9.4.- 1: De met de indirecte funduscoop geconstateede fundus-pathologie; absolute aantallen.

Fundus-pathologie

Aantal

Fundus hypertonicus; nauwe arteriolen, wijde venen

23

Fundus hypertonicus; bloedingen

Fundus hypertonicas; cotton wools

Diabetische retinopathie; microaneurysmata

Diabetische retinopathie; bloedingen en exsudaten

Diabetische retinopathie; vaatproliferaties

Fundus arterioloscleroticus; overkruising: vene niet transparant

Fundus arterioloscleroticus; , owerkruising: ingedtukte vene

Fundus arteriolos cleroticus", zilverdraadarteriolen

Takalsluiting vena centralis retinae

Andere vaatpathologie in fundo

Macula; geringe pigmentafwijkingen

Macula; duidelijke maculadegeneratie

Macula; veel Drusen

Papil; papiloedeem

Papil; peripapillaire atrofie

Papil; C/D verdacht voor glaucoom 
Ophthalmoscopie met de indirecte funduscoop leverde in total 79 bevindingen van nog niet eerder ontdekte fundus-pathologie op.

Oogfundusafwijkingen kunnen voorboden zijn van ernstige aandoeningen, of zijn reeds een indicatie van een ernstige toestand. Bij tien patienten met hypertensie gaven de fundusbewindingen een indicatie tot stringentere regulering van de bloeddruk. Bij zes diabeten was de fundus niet normaal. 18 maal werden duidelijke verschijnselen van arteriolosclerosis gezien. Bij onderzoek van de macula bleek deze elf maal njet normaal te zijn. Dirie maal deden de C/D- bevindingen het bestaan van een glaucoom vermoeden.

Er zij op deze plaats nogmaals geattendeerd op het feit, dat in de morbiditeitsregistraties van Oliemans, Nijmegen, Lamberts en Hodgkin niet apart melding wordt gemaakt van fundusafwijkingen (zie hoofdstuk 7).

\subsection{De relatie tussen het gebruik van de applanatietonometer en de diagnose}

In relatie tot het gebruik van de applanatietonometer kan alleen maar de diagnose glaucoom aan de orde komen.

Zonder tonometer van welk type dan ook is het niet mogelijk verhoogde druk vast te stellen. Het vaststellen van de druk met de wijsvingers van beide handen moet als obsoleet worden beschouwd, daar op deze manier alleen extreem hoge drukken kunnen worden ontdekt.

Er kan hier geen vergelijking worden gemaakt tussen de uitkomsten van onderzoek met de applanatietonometer met die van de Schiötz tonometer en de Glaucotest, omdat deze hulpmiddelen niet (meer) werden gebruikt. De argumenten van de onderzoeker om de applanatietonometer te gebruiken waren:

- de mogelijkheid om hiemee de oogdruk kwantitatief te meten, hetgeen met de Glaucotest niet mogelijk is.

- de grotere betrouwbaarheid van de meetmethode ten opzichte van de andere methoden.

- de eenwoud van de procedure ten opzichte van de andere methoden: tijdens spleetlamp-onderzoek kan de oogdruk beiderzijds binnen een minuut worden bepaald, terwijl de patient voor de andere methoden speciaal moet gaan liggen.

De waarde van de applanatietonometer kan goed worden gedemonstreerd door vergelijking van de op deze wijze verkregen conclusies ten aanzien van glaucoom met een "goede" standaard. Naar aanleiding van tabel 9.5.- 2 wordt hierop ingegaan.

Het aantal malen, dat de applanatietonometer werd gebruikt is weergegeven in tabel 9.5. 1. Hierbij is onderscheid gemaakt tussen gebruik op indicatie en gebruik in het kader van surveillance. Onder gebruik op indicatie wordt hier verstaan: gebruik bij vage klachten zoals hoofdpijn en gebruik bij de wens van de patiënt zijn oogdruk te laten meten.

Tabel 9.5.- 1: Gebrik van de applanatietonometer.

Aantall 
Blijkens de tabel werd de oogdruk voornamelijk in het kader van surveillance gemeten.

Op grond van de verkregen informatie betreffende de oogdruk en de beoordeling van de papil werd gedifferentieerd tussen:

- zeer waarschijnlijk geen glaucoom: 218 maal

- misschien glaucoom: 24 maal

- zeer waarschijnlijk wel glaucoom: 6 maal

Het leek interessant, bovenstaande diagnostische hypothesen te relateren aan de uiteindelijk gestelde diagnose. Daarmee verkrijgt men bij benadering een indruk van de voorspellende waarde van de eerstelijns diagnose.

Als "goede" standaard werd het oordeel van de oogarts genomen. Echter, de oogarts heeft geen oordeel uitgesproken over diegenen die NIET naar hem werden verwezen.

Als "goede" standaard voor de niet-verwezenen werd ingevoerd: al of niet gebleken glaucoom na een aantal jaren (peildatum vijf jaar na beeindigen van de registratie).

De hypothese "geen glaucoom" werd door de follow-up geen enkele keer gefalsificeerd. Van degenen die wel naar de oogarts werden verwezen (11), had de helft daadwerkelijk een glaucoom.

Tabel 9.5.- 2 is een vierveldentabel waarin de test "huisarts" wordt gerelateerd aan de goede standaard.

Tabel 9.5.- 2: Werkhypothesen ten aanzien van ghoucoom vergeleken het een "goede" stavidaard.

\begin{tabular}{lccc}
\hline & \multicolumn{2}{c}{$\begin{array}{c}\text { "Goede" standiard } \\
\text { oogarts/follow-up }\end{array}$} & \\
\cline { 2 - 4 } Huisarts & Glaucoom & Geen glaucoom & Totaal \\
\hline Glaucoom & 6 & 5 & 11 \\
Geen glaucoom & 0 & 233 & 233 \\
\hline Totaal & 6 & 238 & 244
\end{tabular}

De sensitiviteit, specificiteit en voorspellende waarden van de eigen hypothesen zijn uit de tabel af te leiden:

$\mathrm{S}_{e^{-}}=26 / 6=100 \%$
$\mathrm{~S}_{\mathrm{P}^{+}}=233 / 238=98 \%$
$\mathrm{PV}^{+}=2 / 11=54 \%$
$\mathrm{PV}^{-}=233 / 233=100 \%$

$\mathrm{PV}^{+}=$voorspellende waardle van een positieve bevinding.

$\mathrm{PV}^{-}=$voorspellende waarde van een negatieve bevinding. 
Op grond van bovenstaande kan men concluderen, dat de werkhypothese: zeer waarschijnlijk geen glaucoom in dit onderzoek steeds werd bevestigd. Indien dit zou gelden voor de huisarts in het algemeen, zou dit betekenen, dat huisartsen die bereid zijn om bij hun patienten boven 40 jaar met een oogprobleem de oogdruk kwantitatief te meten en de papil te beoordelen, bijna met $100 \%$ zekerheid een glaucoom kunnen uitsluiten. Van degenen die alsnog naar de oogarts zouden worden verwezen voor verdere glaucoomdiagmostiek, zou volgens bovenstaande gegevens ruim de helft een glaucoom hebben. Een voorspellende waarde van ruim $50 \%$ ten aanzien van een ernstige oogziekte als glaucoom kan als excellente eerstelijns diagnostiek worden beschouwd. Bovenstaande berekening berust echter op relatief kleine aantallen en behoeft nadere bevestiging.

\subsection{Samenvatting en conclusies}

In dit hoofdstuk is weergegeven, welke diagnosen werden gesteld met gebruikmaking van de verschillende tests en instrumenten. In totaal werd van 13 verschillende hulpmiddelen gebruik gemaakt; het meest van de spleetlamp, gevolgd door de indirekte fundoscoop en de visuskaart. Het aantal aandoeningen waarvan mag worden aangenomen, dat zij zonder deze instrumenten niet of veel moeilijker c.q. later zouden zijn opgespoord, is aanzienlijk. Een niet gering deel daarvan kon worden gerekend tot de potentieel gevaarlijke aandoeningen, zoals acute uveïtis anterior, glaucoom en een groot aantal fundusafwijkingen. Het vermijden van doktersdelay is daarbij van groot belang.

Van belang is ook de negatieve diagnostiek, bedreven met de geregistreerde hulpmiddelen. Bij klachten over het zien vormde deze de rechtvaardiging voor de 160 verwijzingen naar de opticien zonder tussenkomst van de oogarts.

De doeltreffendheid van de glaucoomdiagnostiek met gebruikmaking van de applanatietonometer en de fundoscoop bleek zeer groot en legitimeerde de beslissing om bij een negatieve uitslag af te zien van verwijzing naar de oogarts ter bevestiging van de diagnose.

De prijs van het pakket aan voor de huisartspraktijk geschikt geachte instrumenten

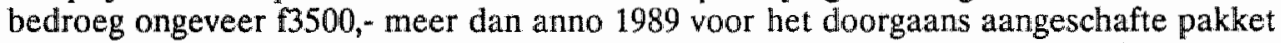
wordt betaald. Naar de mening van de onderzoeker werd deze extra investering ruimschoots gerechtvaardigd door de ruimere diagnostische mogelijkheden. 


\section{Hoofdstuk 10}

\section{SLECHTZIENDHEID EN BLINDHEID: MORBIDITEIT EN PREVENTIE}

\subsection{Inleiding}

In dit hoofdstuk wordt het preventief diagnostisch handelen besproken.

Doorgaans maakt men onderscheid in primaire, secundaire en tertiaire preventie (Sturmans 1982).

De afbakening van de ene vorm van preventie van de andere is niet altijd eenvoudig. Ook niet in de oogheelkunde.

In het vervolg zal de term "preventie" worden gebruikt voor het kenschetsen van al dat diagnostisch handelen, dat gericht is op het voorkomen van blijvende schade aan het gezichtsvermogen. Het gaat daarbij deels om secundaire preventie (vroegdiagnostiek), deels om tertiaire preventie (voorkomen van erger).

In paragraaf 10.1 wordt ingegaan op het voorkomen van blindheid en slechtziendheid.

In paragraaf 10.2 zullen eerder gepresenteerde gegevens ( 8.1 en 8.2 ) nogmaals worden besproken maar nu vanuit het oogpunt van preventie.

\subsection{Slechtziendheid en blindheid; invaliditeit door oogziekten}

Volgens de WHO-criteria heeft een blinde een visus van minder dan $2 / 60$. Een slechtziende heeft een visus tussen $2 / 60$ en 0.4 .

In het eigen onderzoek zijn de slechtzienden en blinden samengenomen, omdat het maken van onderscheid hiertussen voor het beleid van de huisarts niet relevant werd geacht (zie ook hoofdstuk methode).

De laatste 25 jaar is er een verschuiving opgetreden in de oorzaken van blindheid in Nederland. De redenen hiervoor zijn, dat de oogheelkundige diagnostiek en therapie voor een aantal oogaandoeningen zijn werbeterd en dat de bevolking is veroudlerd (Ten Doeschate 1982a, 1982b).

In tabel 10.1 - 1 worden de jaren 1957 en 1979 met elkaar vergeleken voor wat betreft de relatieve frequentie van voorkomen van de oorzaken van blindheid, bij alle geregistreerde gevallen van blindheid in Nederland (Ten Doesschate 1982a, 1982b). 
Tabel 10.1. 1: Relatieve frequenties vert oorzaken van blindhed in Nederland.

\begin{tabular}{|c|c|c|}
\hline & $\begin{array}{c}1957 \\
\%\end{array}$ & $\begin{array}{c}1979 \\
\% \\
\end{array}$ \\
\hline Narvus Opticus atrofie & 12.7 & 16.2 \\
\hline Glaucoom & 11.5 & 5.7 \\
\hline Diabetische retinopathis & 5.0 & 21.0 \\
\hline Seniele maculadegeneratic & 3.8 & 6.7 \\
\hline Vasculaire retinopathie & 2.4 & 3.0 \\
\hline Seniel cataract. & 1.0 & 2.0 \\
\hline Hooggradige myopie & 4.7 & 9.2 \\
\hline Restgroep & 58.9 & 36.2 \\
\hline Total & 100 & 100 \\
\hline
\end{tabular}

Het aandeel van blindheid ten gevolge van glaucoom is aanzienlijk verminderd, zeer waarschijnlijk mede ten gevolge van vroegtijdiger opsporing en behandeling.

Het aandeel van diabetische retinopathie als oorzaak van blindheid is sterk toegenomen. De verklaring hiervoor is, dat diabetische retinopathie niet zozeer gekoppeld is aan een oudere leeftijdsgroep, maar aan de duur van de diabetes. De zorg voor de diabeet heeft zich de laatste decennia geïntensiveerd, waardoor men langer als diabeet door het leven gaat.

Tabel 10.1.-2 geeft een aantal oorzaken van blindheid bij de bevolkingsgroep van 65 jaar en ouder in Framingham, Verenigde Staten, zoals geregistreerd in thet jaar 1973 (Braam 1984).

Tabel 10.1.- 2: Seniel cataract, glaucoom, diabetische retinopathie en seniele maculadegeneratie als oorzaken van blindheid bij personten van 65 jaar en ouder in Framingham als percentage van de leefijdsgroep.

Leeftijd

Seniel cataraci

Glaucoom

Diabetische retinopathic

Senicle maculadegeneratie
65

2.6

0.7

11.1

0.6
$65-75$

9.7

1.7

1.7

4.1
$>75$

33.7

2.9

3.0

15.4

Het relatieve aandeel van de hier genoemde aandoeningen binnen de groep van blinden boven 65 jaar neemt drastisch toe. Dit is op zich niet verwonderlijk, daar het hier o.a. gaat om blindheid ten gevolge van oogaandoeningen die niet of slechts ten dele behandelbaar zijn, zoalls seniele maculadegeneratie en diabetische retinopathie.

Het percentage blinden in Framingham ten gevolge van cataract is, vooral in de leeftijdsgroep van 75 jaar en ouder, erg hoog. Waarschijnlijk zijn hier bedoeld de nog niet geopereerden. Zelfs dan is het percentage echter verbazingwekkend.

De toename van blindheid met de leeftijd ten gevolge van glaucoom is een punt van aandacht. Bij een adlekwate vroege opsporing zou een dergelijke toename zich niet hoeven voordoen. De drastische toename van blindheid ten gevolge van seniele 
maculadegeneratie met de leeftijd komt voort uit het feit, dat dit een typische ouderdomsziekte is waarvoor nog geen behandeling bestaat.

Ook in het eigen onderzoek is het voorkomen van slechtziendheid en blindheid nagegaan, alsmede de vermeende oorzaken hiervan.

De resultaten van het onderzoek naar de gezichtsscherpte bij de 748 in ons onderzoek gepresenteerde oogproblemen worden vermeld in tabel 10.1.- 3 .

Tabel 10.1.. 3: $\quad$ Resultaat visusonderzoek bij de geregistreerde 748 oogproblemen, weergegeven voor her linker (OS) en het rechter oog (OD) apart.

\begin{tabular}{lrrrrr}
\hline & \multicolumn{5}{c}{ OS } \\
\cline { 2 - 6 } OD & $<0.4$ & $0.4-1.0$ & $>1.0$ & Niet $^{1}$ & Total \\
\hline$<0.4$ & $15^{2}$ & $15^{2}$ & $8^{2}$ & $1^{2}$ & \\
$0.4-1.0$ & $10^{2}$ & $86^{2}$ & $39^{2}$ & - & \\
$>1.0$ & $5^{2}$ & $24^{2}$ & 163 & - & \\
Niet & $1^{2}$ & - & 1 & 380 & \\
\hline
\end{tabular}

Totaal

748

Visus niet onderzocht/geregistreerd.

Visus aan een of beide ogen minder dan 1.0

Uit tabel 10.1.- 3 blijkt, dat 163 maal de visus aan beide ogen gelijk of meer was dan 1.0 en dat 204 maal een visus van minder dan 1.0 aan eén of beide ogen werd geconstateerd ?

Omdat bij degenen met een visus minder dan 0.4 van é́n of beide ogen geen dubbeltellingen betreffende personen voorkwamen, kan verder worden geconcludeerd, dat in totaal 55 personen slechtziend/blind waren aan één of beide ogen, walarvan 15 aan beide ogen en 40 aan é̉n oog.

De aandoeningen welke als waarschijnlijke (mede)-oorzaak van slechtziendheid/blindheid werden beschouwd, worden weergegeven in tabel 10.1.- 4. Aangegeven wordt, of de aandoening werd ontdekt bij surveillerend onderzoek ("surveillance"), dan wel, dat hiernaar werd gezocht naar aanleiding van een specifieke oogklacht ("klachtgericht"). Ook reeds bekende aandoeningen worden als zodanig aangegeven ("bekend").

Refractieafwijkingen en cataract zijn blijkens de tabel de belangrijkste veroorzakers van slechtziendheid/blindheid in dit onderzoek. Beide aandoeningen kunnen in de meerderheid der gevallen goed worden gecorrigeerd c.q. behandeld. Op de derde plaats komt de amblyopie, die in alle gevallen reeds bekend was. Uiteraard is hier geen behandeling meer mogelijk. 
Trbel 10.1. 4. Aastallen en and van de diagnosen verantwoordelijk voor de slechtziendheid/blindheid,

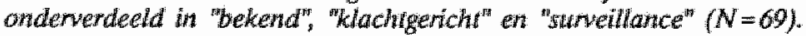

\begin{tabular}{|c|c|c|c|c|}
\hline Diagrose & Bekend & $\begin{array}{l}\text { Klacht- } \\
\text { gericht }\end{array}$ & $\begin{array}{l}\text { Surved- } \\
\text { lance }\end{array}$ & Totaal \\
\hline Refracticafwitkingen & 1 & 18 & 3 & 22 \\
\hline Chronische uiveitis anterior & 1 & - & - & $\mathbb{1}$ \\
\hline Cataract & 1 & 13 & 8 & 22 \\
\hline Afakie & $\mathbb{1}$ & 一 & $=$ & $\mathbb{1}$ \\
\hline Bloeding in corpus vitreum & - & 1 & . & 1. \\
\hline Oude chorioretinitis & - & 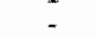 & 1 & 1 \\
\hline Takafsluiting vena centralis retinae & - & $=$ & 1 & 1 \\
\hline Macula-afwijkingen & 2 & 3 & 2 & 7 \\
\hline Opticusncuropathie & 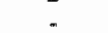 & 1 & $=$ & 1 \\
\hline Peripapillaire atrofie & - & 1 & 1 & 2 \\
\hline Amblyopic & 10 & - & . & 10 \\
\hline
\end{tabular}

Totaal

16

37

16

69

Opvallend is, dat noch glaucoom, noch diabetische retinopathie in het rijtje voorkomen, terwijl deze aandoeningen in de eerder gepresenteerde tabellen een belangrijke plaats innemen. De meest voor de hand liggende verklaring hiervoor is, dat mensen met deze aandoeningen, eenmaal opgespoord, in de regel onder controle van de pogarts blijven en in de registratieperiode niet (met oogklachten) op het spreekuur van de huisarts zijn geweest. Ook vroege detectie en behandeling van genoemde aandoeningen kan echter hieraan hebben bijgedragen.

Verder blijkt dat een kwart van de aandoeningen reeds tevoren bekend waren, ruim de helft werd gediagnostiseerd op geleide van een klacht en een kwart werd opgespoord in het kader van surveillance.

Ruim tweederde van de bij surveillance opgespoorde aandoeningen (refractieafwijkingen en cataract) kan worden gecorrigeerd c.q. behandeld, met als gevolg (gedeeltelijk) herstel van de visus.

\subsection{Op preventie gericht diagnostisch handelen}

\section{2,1 Nieuw gediagnostiseerde potentieel gevaarlijke aandoeningen}

Combinatie van gegevens uit de paragrafen 8.1 en 8.2 biedt de mogelijkheid na te gaan, welk deel van het totale diagnostisch handelen was gericht op preventie van blijvende gezichtsschade.

Daarbij gaat het om het opsporen van niet eerder bekende voor de visus potentieel gevaarlijke oogaandoeningen bij bestaande oogklachten (8.1) en om surveillance bij het vermoeden van dergelijke oogaandoeningen, welke vooralsnog niet tot oogklachten leidden (8.2).

In tabel 10.2.1.- 1 wordt hiervan een overzicht gegeven. Opsporen van aandoeningen die potentieel gevaar opleveren voor het gezichtsvermogen stoelde volgens deze gegevens drie maal vaker op surveillerend onderzoek dan op het klachtgericht onderzoek van het oog. 
Met name de ophthalmoscopie en de oogdrukmeting leverden een belangrijke bijdrage. Niet alle opgespoorde aandoeningen zijn behandelbaar of in hun beloop te beïnloeden, de meeste echter in principe wel.

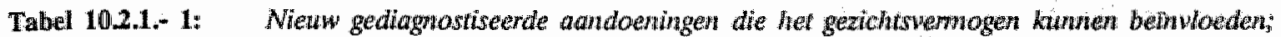
klachtgericht en sumeillenend ontdekt (absolkte aantallen).

Bevindingen
Inflammatoire aandoeningen
- ophthalmia neonatorum
- keratitis dendritica
- acute uveitis anterior
Melanoom conjunctivae
Cataract
Glasvochtbloeding
Macula-afwijkingen
Vasculaire retinopathieën
- fundus hypertonicus
- diabetische retinopathie
- fundus arterioloscleroticus
- andere vaatpathologie
Papiloedeem
Peripapillaire atrolie
Misschien glaucoom
Waarschijnlijk glaucoom
Strabismus

Totaal
Klacht- Surveil-

gericht lance Total

$\begin{array}{ccc}1 & - & 1 \\ 2 & - & 2 \\ 3 & - & 3 \\ 2 & - & 2 \\ 24 & 43 & 67 \\ 1 & - & 1 \\ 4 & 11 & 15\end{array}$

$\begin{array}{ccc}1 & 34 & 35 \\ 1 & 4 & 5 \\ - & 19 & 19 \\ 2 & 2 & 4 \\ - & 2 & 2 \\ 1 & 3 & 4 \\ 1 & 24 & 25 \\ 1 & 3 & 4 \\ 4 & - & 4\end{array}$

193

\subsubsection{Oogziekten van belang in het kader van preventie.}

De belangrijkste categorieën van aandoeningen, waarbij preventie van bljjvende gezichtsschade door medisch ingrijpen in principe mogelijk is, zullen worden besproken, te weten: glaucoom, diabetische retinopathie en andere vasculaire retinopathieën, inflammatoire aandoeningen en aandoeningen bij zuigelingen en kleuters. Het cataract blijft verder buiten beschouwing, ondat herstel van het gezichtsvermogen niet afhankelijk is van tijdige opsporing.

\subsubsection{Glaucoom}

Bij langer bestaande verhoogde oogdrukken ontstaat op den duur gezichtsvelduitval in de vorm van scotomen (allereerst vezelbundelscotomen, later ook centraal). Deze gezichtsvelduitval is irreversibel. Indien het primair chronisch glaucoom in een vroeg stadium wordt onderkend, is therapie door de oogarts mogelijk en kan blijvende gezichtsschade worden voorkomen.

Reeds eerder (9.5) is aangegeven, hoe vaak naar het voorkomen van primair chronisch glaucoom is gezocht en wat daarvan het resultaat was.

244 maal werd de oogdruk kwantitatief gemeten, terwijl 362 maal de oogfundus werd bekeken waarbij ook aandacht werd besteed aan mogelijke glaucomateuze veranderingen van de papil. Elf patienten $(4.5 \%)$ werden voor verdere 
glaucoomdiagnostlek naar de oogarts verwezen. Daarvan hadden volgens de oogarts zes patienten glaucoom $(2.4 \%)$ en vijf niet.

Van Rens (1976) vermeldt voor personen bowen 65 jaar een verwijspercentage naar de oogarts van $9.1 \%$ ten behoeve van verdere glaucoomdiagnostiek. Uiteindelijk bleek $4.7 \%$ van het totaal der onderzochte patienten een primair chronisch glaucoom te hebben. Bij van Rens ging het echter om een bevolkingsonderzoek.

\subsubsection{Diabetische retinopathie}

Wanneer een diabetes langer bestaat, kan in het retinale stroomgebied ischemie ontstaan, waardoor de vorming van vaatnieuwvorming, vaatproliferatie, wordt bevorderd. Door deze proliferaties treden gemakkelijk bloedingen op.

Preventie van gezichtsschade door dergelijke bloedingen is mogelijk door het afsluiten van de ischemische gebieden met behulp wan lasercoagulatie.

Een beginnende diabetische retinopathie geeft geen klachten, en is voor de patiënt geen aanleiding de huisarts/oogarts te consulteren. Wanneer de diabeet ernstige visusklachten ten gevolge van zijn diabetische retinopathie gaat ondervinden, is het ziekteproces meestal zo ver voortgeschreden, dat de patiënt zijn beste kansen heeft gemist. Hieruit resulteert de noodzaak bij diabeten zonder fundusafwijkingen regelmatig de fundus te onderzoeken (Reitsma 1985, Oosterhuis 1984, Kanski 1985, Baggen e.a. 1986).

Onder de 36 in dit onderzoek onderzochte diabeten werden de volgende uitingswormen van retinopathie opgespoord:

- minstens één microaneurysma $(2 x)$

- bloedingen en exsudaten (3x)

- glaswochtbloedingen (1x)

Van de drie patienten met exsudaten en bloedingen weigerde én persoon konsekwent een oogarts te consulteren, én patiënt had een dusdanig slechte lichamelijke conditie dat redelijkerwijs weinig profijt was te verwachten van een bezoek aan de oogarts, de derde patiënt had inderdaad eerder naar de oogarts moeten worden verwezen.

De patiënte met glasvochtbloedingen was voor haar diabetische retinopathie onder controle van een oogarts, maar meldde zich bij de huisarts omdat ze plotseling met én oog niets meer kon zien.

Uit bovenstaande valt het volgende te concluderen: meer dan $80 \%$ van de onderzochte diabeten bleek op het moment van onderzoek geen tekenen te vertonen valn een diabetische retinopathie. Hen is een gang naar de oogarts bespaard. Een kleine $20 \%$ had min of meer ernstige afwijkingen, welke om oogheelkundig ingrijpen vroegen. Hen is mogelijk (verder) verlies van gezichtsvermogen bespaard.

\subsubsection{Overige vasculaire retinopathieën}

Ernstige vaatafwijkingen in het oog in de zin van een totale afsluiting hebben doorgaans een blijvend gezichtsverlies van het betreffende oog of uitval van een gedeelte van het gezichtsveld tot gevolg. Het betreft hier meestal trombo-embolieën. Andere vasculaire retinopathieën, zich manifesterend in bloedingen en cotton-wools zijin meestal reversibel. Het belang van het opsporen van deze laatste groep ligt voornamelijk daarin, dat de conditie van de vaten in de fundus een indicatie vormt voor de conditie van hart en bloedvaten van de patiënt (Gunn 1904, Scheie 1953, Hagedoorn 1963, Gifford 1969, Crone 1977, Perloff e.a. 1983). De algemene 
complicaties van hypertensie en vatselerose zijn ernstig: hartinfarct, hersen-bloeding c.q. -infarcering, nierschorssclerose en afsluiting van perifere vaten.

Adekwate behandeling van hypertensie kan veel van deze complicaties voorkomen. Een hypertensie is tegenwoordig doeltreffend te behandelen. De huisarts kan de effectiviteit van zijn behandeling toetsen door het meten van de bloeddruk, door het maken van electrocardiogrammen, en door de bloedvaten in fundo te bekijken.

Vanuit een oogpunt van preventie is het niet zozeer de bedoeling patienten met de hierboven beschreven vaatafwijkingen te verwijzen naar een oogarts, maar veeleer het algehele vaatlijden van de patiënt meer aandacht te geven. Hypertensieve retinopathieën duiden op een slechte prognose en vormen een signaal om de bloeddruk nog stringenter te behandelen.

In de onderzoeksperiode werd in total 362 maal de oogfundus bekeken. Onder de onderzochten bevonden zich 111 personen met hypertensie en 33 personen met een cardiovasculair accident in de anamnese. In de meeste gevallen werd de fundus onderzocht in het kader van surveillance (dus op initiatief van de arts). De hierbij aangetroffen afwijkende ophthalmologische bevindingen staan vermeld in tabel 10.2.2.3.- 1 .

Tabel 10.2.2.3.- 1. Bij fundoscopie gevonden uitingen van vaatafinikingen, exchsief diabetische retimopathie $(N=362)$.

Uiting

Fundus hypertomicus

* nauwe arteriolen

- bloedingen

- cottonwool-exudaten

Totaal

Fundus arterioloscleroticus

- een niet transparante vene bij overkruising

- ingedrukte bloedkolom bij overkruising

- zilwerdraadarteriolen

- takafsluiting wena centralis retinae

Totaal

Andere vaatpathologie

Aantal

15

8

2

25

18

4

Totakl aantal afwijkende bevindingen

47

In totaal werden dus bij meer dan $10 \%$ van de op funduspathologie onderzochte personen afwijkingen aan de vaten geconstateerd.

De volgende casus illustreert het belang van dergelijke informatie als leidraad bij de behandeling van hypertensie.

Bij een man van 54 jaar met hoofdpijn werd een bloeddruk van $270 / 130$ gemeten.

Bij ophthalmoscopie werden in de rechter oogfundus cotton wool-exsudaten gezien; 
in de linker oogfundus tevens een, door vaatspasmen, ischemisch gebied waarin bloedingen en beginnende vaatproliferaties te zien waren.

Met antihypertensiva normaliseerde de bloeddruk zich snel. De cottoncool-exudaten waren reeds na een dag verdiwener.

Zeven maanden later waren in de linker oogfundus de vaatproliferaties nog duidelijk aanwezig. Echter, sommige afgesloten vaten waren wederom geopend.

13 maanden later werd een regressie van de vaatproliferaties waargenomen.

\subsubsection{Preventie van blijvende gezichtsschade bij zuigelingen en kleuters}

Tijdens de onderzoeksperiode werden twee kleuters van én jaar en twee van drie jaar wegens vermoede of manifeste oogstandafwijkingen naar de oogarts verwezen voor amblyopiebehandeling.

Eén pasgeborene met ophthalmia neonatorum werd met spoed verwezen naar de oogarts om een gonococceninfectie uit te sluiten. Achteraf bleek een banale infectie bij een afgesloten ductus nasolacrimalis de ophthalmia te hebben veroorzaakt.

\subsubsection{Inflammatoire oogaandoeningen}

Ontstekingen van conjunctiva, oogleden, cornea, iris en corpus ciliare zijn vaak selflimiting, maar kunnen in sommige gevallen ernstig zijn en bij niet tijdige onderkenning het oog chronisch irriteren of blijvend beschadigen.

Een niet direct herkende en niet direct behandelde herpes simplex-keratitis kan na enkele dagen overgaan in een diepe stromale keratitis, die moeilijk is te behandelen, vaak recidiveert en op den duur totaal verlies van het gezichtsvermogen tot gevolg kan hebben (Van Bijsterveld en Post 1981, La Lau e.a. 1981, Goudsmit en van der Noordaal 1983, Baggen 1985). Doordat het allerprilste stadium wan de ziekte zonder spleetlamp door de huisarts veelal niet is te diagnostiseren, wordt de ziekte in dat stadium niet vaak herkend. Bovendien komen artsen wel eens in de verleiding om corticosteroid-houdende oogdruppels of zalf te geven, hetgeen in dit geval fataal kan zijn. Het gaat hier niet om sporadische gevallen: in Engeland worden per jaar ongeveer 750 personen visueel gehandicapt, doordat corticosteroiden werden gegeven bij een herpesinfectie van het oog. (Wilson 1987).

Sinds de introductie van het geneesmiddel acyclovir is vroegdiagnostiek van een herpes simplex-keratitis nog dankbaarder. Direct toedienen van het geneesmiddel acyclovir bif het begin van de aandoening voorkomt, dat het virus het stroma van de cornea binnendringt (Van Bijsterveld en Post 1981, Baggen 1985).

Gedurende de onderzoeksperiode werd twee maal een keratitis dendritica gezien. Beide patienten kregen acyclovir, waarop ze binmen eén dag klachtenvrij werden. Recidieven traden niet op.

N.B. In de jaren na de registratieperiode werden vier gevallen van keratitis dendritica in een vroeg stadium gediagnostiseerd, welke na ến dag genazen en niet recidiveerden.

Elf maal werd een keratitis marginalis in het beginstadium gezien. Deze aandoening geeft doorgaans geen ernstige oogklachten, waardoor het nog al eens voorkomt dat adekwate therapie laat wordt ingesteld; zonder spleetlamp is de aandoening nauwelijks te diagnostiseren; macroscopisch gelijkt ze aanvankelijk op een conjunctivitis.

Een beginnende keratitis marginalis geneest snel na toediening van corticosteroiden. Een langer bestaande keratitis marginalis moet doorgaans langdurig worden behandeld 
met corticosteroïden, met alle gevaren van dien (Colen-brander 1971, Henkes 1977, Claque en Stevenson 1986).

Vier maal werd een acute uveitis anterior gezien. De prognose van iritis en iridocyclitis hangt voor een deel af van het stadium waarin behandeling wordt ingesteld (Henkes en van Balen 1983). De vier gevallen van iritis c.q. iridocyclitis werden bij de eerst voorkomende symptomen als zodanig onderkend en konden direkt adekwaat worden behandeld.

\subsection{Samenvatting en conclusies}

Het totaal aantal gevallen van slechtziendheid/blindheid aan eén of beide ogen was hoog: het betrof acht procent van de onderzochte personen. In een vierde van de gevallen bleek de patiënt zich niet bewust van deze handicap. De gevonden oorzaken van slechtziendheid/blindheid waren divers van aard. In totaal werden elf verschillende diagnosen gesteld. In een derde van de gevallen betrof het een cataract. In ruim $40 \%$ van de gevallen was de afwijking gelokaliseerd in de fundus.

$85 \%$ van de 107 aandoeningen welke een potentieel gevaar voor de visus opleverden, werd un het kader van surveillance opgespoord. Een aantal van de gevonden aandoeningen vereiste onmiddellijk ingrijpen. De meeste daarvan waren van dien aard, dat bij therapeutisch ingrijpen in principe (verder) verlies van gezichtsvermogen zou kunnen worden voorkomen.

De balans opmakend kan men stellen, dat op preventie gericht handelen een substantieel onderdeel uitmaakte van het totaal aantal diagnostische verrichtingen gericht op het opsporen van potentieel ernstige oogaandoeningen. De hieraan bestede tijd werd meer dan gerechtvaardigd door het total aan gevonden aandoeningen waarbij tijdige behandeling behoud van het gezichtsvermogen zou kunnen betekenen. Verwijzing geschiedde doorgaans onmiddellijk na opsporing en onnodig verwijzen werd voorkomen door risicogroepen bij wie geen afwijkingen werden gevonden zelf te vervolgen.

Voor het vormgeven van een goede huisartsgeneeskundige oogheelkunde vormen de hier gepresenteerde bevindingen ons inziens een belangrijk gegeven. 



\section{Hoofdstuk 11}

\section{SAMENVATTING VAN DE RESULTATEN, CONCLUSIES EN BESCHOUWING}

\subsection{Inleiding}

In dit hoofdstuk zullen allereerst de belangrijkste resultaten worden geresumeerd, voorzover deze bijdragen aan de beantwoording van de diverse onderzoekswragen (11.1). Vervolgens worden enkele kanttekeningen bij de onderzoeksopzet besproken (11.2).

Een reflectie volgt ten aanzien van de betekenis van de uitkomsten voor de eerstelijns oogheelkunde (11.3).

\subsection{De resultaten in relatie tot de onderzoeksvragen}

Onderzoeksvraag A: Met welk probleemaanbod - in termen van diagnosen op het gebied van de oogheelkunde - werd de huisarts in deze praktijk geconfronteerd?

In totaal werden in anderhalf jaar tijd 910 consulten aan 748 oogheelkundige problemen besteed bij 685 personen. Omgerekend naar een aanbod per jaar in een normpraktijk (2250), komt dit neer op ongeveer éen oogheelkundig consult per werkdag en eén oogheelkundig onderzoek bij $10 \%$ van de praktijkbevolking per jaar.

Van de oogproblemen werd meer dan $80 \%$ in een eenmalig consult afgehandeld. In $70 \%$ der gevallen betrof het een nog niet eerder bekend probleem.

$\mathrm{Bij}$ ouderen werd vaker oogonderzoek verricht dan bij jongeren. $25 \%$ wan het oogheelkundig probleemaanbod kwam uit de leeftijdscategorie 45-64 jaar. $30 \%$ uit de leeftijdscategorie 65 jaar en ouder.

Een kwart van de hoofddiagnosen betrof refractieproblematiek. In driekwart wan de gevallen werd een andere oogheelkundige diagnose gesteld. Uit de incidentielijst blijkt dat in anderhalf jaar het gehele palet aan bekende categorieën van oogheel'kundige afwijkingen werd gezien. Veel afwijkingen werden slechts een enkele maal

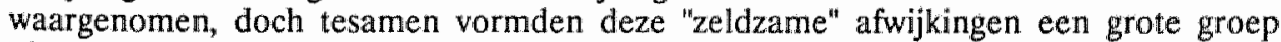
binnen het totaal van gestelde diagnosen. Hetzelfde kan gezegd worden van de 107 
potentieel gevaarlijke aandoeningen. Deze bleken als groep bepaald geen zeldzaamheid.

De incidenties van de in dit onderzoek gediagnostiseerde aandoeningen werden vergeleken met die uit het monitoringproject van Ommoord (Lamberts), de Continue Morbiditeits Registratie van Nijmegen en de registraties van Oliemans en Hodgkin. De belangrijkste uit deze vergelijking naar voren komende bewindingen zijn de volgende:

- De incidentiecijfers betreffende oogaandoeningen die doorgaans gepaard gaan met het symptoom: rood oog, lagen bij allen om en nabij de 25 (per 1000 per jaar). Het aantal verschillende diagnosecategorieën was in het eigen registratiesysteem echter aanzienlijk groter. Diagnosen werden gesteld behorende tot elk van deze categorieën; met andere woorden: geen enkele diagnosecategorie bleef "leeg".

- Het incidentiecijfer voor cataract lag in het eigen onderzoek beduidend hoger evenals dat voor glaucoom.

- Fundusafwijkingen kwamen in het eigen onderzoek frekwent voor: n.l. 13 per 1000 tot de praktijk behorende patiënten per jaar. Een vergelijking met de aantallen gediagnostiseerde fundusafwijkingen bij de anderen was niet mogelijk, daar een aparte categorie hiervoor bij hen ontbrak (!).

Onderzoekswraag B: In hoeverre betrof het diagnosen van belang in het kader van preventie van verminderd gezichtsvermogen?

In totaal werd 107 maal een aandoening gediagnostiseerd, welke kon worden beschouwd als potentieel schadelijk woor het gezichtsvermogen. Een aantal malen was onmiddellijk ingrijpen vereist, terwijl de meeste van deze aandoeningen van dien aard waren, dat bij therapeutisch ingrijpen in principe (verder) verlies van gezichtsvermogen zou kunnen worden voorkomen.

Slechts in een kwart van de gevallen was een klacht van de patiënt aanleiding tot onderzoek van het oog. Dit was onder andere het geval bij alle negen gediagnostiseerde "gevaarlijke" inflammatoire aandoeningen.

Daarentegen werd drie kwart van de voor het gezichtvermogen schadelijke aandoeningen opgespoord in het kader van surveillerend onderzoek, verricht op initiatief van de arts.

Cataract, (mogelijk) glaucoom en fundusaandoeningen vormden het overgrote deel van de gevonden potentieel schadelijke aandoeningen. Deze werden, begrijpelijkerwijze, met name aangetroffen bij personen boven 65 jaar.

55 personen bleken slechtziend/blind aan een of beide ogen, hetgeen neerkomt op $8 \%$ van thet totaal aantal onderzochten. Een derde van deze slechtzienden/blinden was zich niet bewust van deze handicap. In $23 \%$ van de gevallen, werd de slechtzlendheid/blindheid opgespoord in het kader van surveillerend onderzoek. Ruim $60 \%$ van de aandoeningen die de oorzaak vormden voor het slechte gezichtsvermogen waren in principe alsnog zodanig behandelbaar, dat herstel dan wel verbetering van het gezichtsvermogen tot de mogelijkheden behoorde. Het betrof hier met name refractieafwijkingen en cataract. Onherstelare schade aan het gezichtsvermogen werd voornamelijk veroorzaakt door fundusafwijkingen en amblyopie.

Onderzoeksuraag $\mathrm{C}$ : Met welke klachten en/of problemen presenteerden de mensen zich bij wie de bovengenoemde diagnosen werden gesteld? 
Oogheelkundig onderzoek werd in veruit de meeste gevallen verticht naar aanleiding van specifieke oogklachten van de patient, in $11 \%$ naar aanleiding van vage, algemene klachten, terwijl in $12 \%$ wan de gevallen de patient geen klachten had, maar werd onderzocht wegens bestaande afwijkingen waarbij oogcomplicaties te verwachten waren.

De specifieke oogklachten betroffen vooral klachten over het zien en klachten over pijn aan het oog; elk in ruim $40 \%$ van de gevallen.

Bij klachten over het zien werd 200 maal een afwijking gevonden die de klacht kon verklaren: refractieafwijkingen namen daarbij de belangrijkste plaats in (148), gevolgd door cataract (17). Verder werd nog 35 maal een andere afwijking geconstateerd, in totaal 19 verschillende.

Hierbij dient vermeld te worden, dat bij klachten over het zien 76 maal gericht gezocht is naar een bepaalde afwijking, zonder dat deze werd gevonden. Dit aantal vormt een indicatie voor de mate waarin de arts de diagnostiek toespitste op het uitsluiten van bepaalde aandoeningen; de zo genoemde "negatieve diagnostiek".

Bij klachten over pijn aan het oog werd ter verklaring van de klacht 205 maal een afwijking behorend tot 33 verschillende diagnosecategorieën geregistreerd. Hieronder bevonden zich tien aandoeningen die gevaar voor verlies van gezichtsvermogen konden opleveren. De gevonden afwijkingen betroffen voornamelijk afwijkingen van het voorste oogsegment. Ook naar aanleiding van deze klacht was het onderzoek vaak, 136 maal, gericht op het uitsluiten van bepaalde aandoeningen die uiteindelijk niet aanwezig bleken.

Surveillerend onderzoek, dat wil zeggen onderzoek verricht op initiatief van de arts, leverde bij specifieke oogklachten in totaal 89 nog niet eerder bekende afwijkingen op. Daarbij ging het 20 maal om een verdenking op glaucoom en 26 maal om oogfundusafwijkingen.

Het onderzoek bij vage, algemene klachten werd steeds verricht op initiatief van de arts. Hierbij werd 43 maal een nog niet bekende oogafwijking gediagnostiseerd. In de helft van de gevallen betrof het een refractieafwijking.

Het surveillerend aogonderzoek bij aandoeningen, waarbij oogcomplicaties te verwachten waren, zoals diabetes en hypertensie leverde 74 mal nog niet bekende afwijkingen op. In 46 van deze gevallen betrof het oogfundusafwijkingen.

Onderzoeksvraag D: Welke oogheelkundige onderzoeksmethoden werden bij het opsporen van bovengenoemde afwijkingen gebruikt?

Een uitgebreid arsenaal van oogheelkundig instrumentarium werd in de jaren voorafgaand aan het onderzoek beproefd.

15 verschillende hulpmiddelen werden gedurende de onderzoeksperiode daadwerkelijk gebruikt. Uiteindelijk bleken de spleetlamp (473 maal), de indirecte funduscoop ( 362 maal), de visuskaart veraf ( 359 maal), de applanatietonometer ( 244 maal) en de leeskaart (155 maal) de vijf meest gebruikte hulpmiddelen. Bij klachten betreffende het zien werden in de meerderheid der gevallen alle hier bovengenoemde hulpmiddelen aangewend; met andere woorden: hierbij werd doorgaans een volledig oogonderzoek uitgevoerd. Bij pijn aan het oog was de spleetlamp veruit het meest gebruikte instrument. In ruim $80 \%$ van de gevallen werd dit hulpmiddel aangewend. Bij vage algemene klachten en bij aandoeningen met mogelijke oogcomplicaties werd de indirekte fundoscoop het meest gebruikt, namelijk in ruim $80 \%$ van de gevallen. 
Ook de spleetlamp, de visuskaart veraf en de applanatietonometer werden echter in bijna de helft van de gevallen aangewend.

De opbrengst van het gebruik van de spleetlamp, de indirecte funduscoop en de applariatietonometer werd uitwoerig onderzocht.

Bij klachten over het zien werd met gebruik van de spleetlamp 183 maall een diagnose gesteld, waarbij inbegrepen 107 "negatieve diagnosen". 94 maal werd bijvoorbeeld geconcludeerd, dat er geen sprake was van cataract.

Bij pijn aan het oog werd met de spleetlamp 300 maal een diagnose gesteld, waarbij het 112 maal om een negatieve diagnose ging.

Naar de mening van de onderzoeker ging het in een groot aantal gevallen van beide categorieën klachten om afwijkingen die zonder spleetlamp niet of slechts met zeer grote moeite zouden zijn ontdekt.

Met de indirecte funduscoop werd 79 maal een fundusafwijking opgespoord. Het ging daarbij vooral om fundusafwijkingen bij hypertensie (55) en diabetes (6), maar ook om macula-afwijkingen verdacht voor maculadegeneratie (11) en cup-disc afwijkingen van de papil passend bij de diagnose glaucoom (3).

De dírecte funduscoop werd niet gebruikt, hetgeen moet worden gezien als uiting van een sterke voorkeur van de onderzoeker voor de indirekte funduscoop.

(Potentiele) glaucoompatienten werden allen opgespoord op geleide van de oogürukken, gemeten met een applanatietonometer en van de papilbevindingen bij ophthalmoscopie. Er werden elf personen naar de oogarts verwezen voor verdere glaucoomdiagnostiek, waarvan zes een glaucoom bleken te hebben. 233 maal werd de diagnose zeer waarschijnlijk geen glaucoom gesteld, welke kwalificatie door de followup nooit werd weersproken. In besliskundige termen uitgedrukt was de sensitiviteit en specificiteit van deze glaucoomdetectie respectievelijk $100 \%$ en $98 \%$.

Onderzoeksvraag E: In welke mate werden de gepresenteerde oogheelkundige problemen door de huisarts zelfstandig afgehandeld dan wel verwezen naar oogarts of opticien?

Voor $11 \%$ van de 748 gepresenteerde problemen ( 81 maal), werd een verwijskaart woor de oogarts afgegevem, wararvan $2 \%$ uitsluitend op uitdrukkelijk verzoek van de patiënt. De resterende 68 verwijzingen (9\%) betroffen voornamelijk verzoeken om therapeutische interventie; in een derde van de gevallen werd verwezen voor verdere diagnostiek. De helft daarvan betrof een verzoek tot nadere glaucoomdiagnostiek.

In $22 \%$ van de 748 gepresenteerde problemen (160 maal), werd verwezen naar de opticien, nadat bij oogheelkundig onderzoek geen andere dan refractieafwijkingen waren geconstateerd. Dit aantal is twee maal zo hoog als het aantal, verwezen naar de oogarts.

Onderzoekswraag F: In hoeverre werd de juistheid van de onder A bedoelde diagnosen door de follow-up bevestigd?

Noch uit de terugrapportage van de oogarts, noch uit de analyse van de patiëntenkaarten in de follow-up-periode van gemiddeld $3 \frac{1}{2}$ jaar kwamen feiten naar voren, die deden twijfelen aan de juistheid van de gestelde diagnosen. Hierbij zij opgemerkt, dat de hypothese mogelijk dan wel waarschijnlijk glaucoom in de helft van de gevallen leidde tot een nader oordeel: geen glaucoom, blijkens de rapportage van de oogarts. 


\subsection{Conclusies}

Bovenstaande resultaten leiden in het licht van de gestelde vragen tot de volgende conclusies:

Gedurende de onderzoeksperiode werd een weids scala van oogheelkundige afwijkingen gediagnostiseerd en wel zodanig, dat het formuleren van een "top $10^{\text {" }}$ onrecht zou aandoen aan de breedte van het domein, waarop de onderzoeker kennis en onderzoeksbekwaamheden van node bleek te hebben om verantwoord oogheelkundige diagnostiek (en therapie) te kunnen bedrijven. Met name bij de leeftijdsgroep van 65 jaar en ouder bleken vele oogheelkundige aandoeningen voor te komen, die niet van onschuldige aard waren.

De klachten geuit door de patiënt, bleken slechts ten dele een goede leidraad voor het formuleren van hypothesen ten aanzien van de aard van de aandoeningen. Met name bij klachten betreffende het zien werd een grote variëteit aan aandoeningen gevonden, gelocaliseerd in de verschillende segmenten van het oog. Preventieve activiteiten, in de vorm van oogonderzoek uitgevoerd op inatiatief van de arts, werden in ruime mate ontplooid en niet zonder resultaat. Vooral door onderzoek bij algemene aandoeningen die gepaard kunnen gaan met oogafwijkingen werden vele, verschillende afwijkingen aangetroffen die een bedreiging zouden kunnen vormen voor het gezichtsvermogen van de patiënt.

Slechtziendheid/blindheid bleek bij nader onderzoek in een niet onaanzienlijk aantal gevallen "niet definitief". Therapie in de vorm van refractiecorrectie en caratactextractie zou een (gedeeltelijk) herstel van het gezichtsvermogen van de patiënt kunnen betekenen.

De aangeschafte oogheelkundige apparatuur werd op grote schaal gebruikt. Aannemelijk werd gemaakt, dat veel van de hiermee gediagnostiseerde afwijkingen met minder sterke optische hulpmiddelen niet zouden zijn ontdekt.

Er bleek sprake van een adekwate diagnosestelling en een laag verwijspercentage, terwijl verwijzing van (potentieel) ernstige aandoeningen veelal vroegtijdig en gericht plaatsvond.

\subsection{Kanttekeningen bij de onderzoeksopzet}

Het hier besproken onderzoek is een descriptief, explorerend onderzoek. Dit betekent, dat er met name sprake is van een verkenning, in dit geval van het oogheelkundig aanbod en de aanpak daarvan in een goed geoutilleerde huisartspraktijk. Een dergelijke opzet stelt duidelijke grenzen aan de mate waarin conclusies ten aamzien van de opbrengst van die aanpak kunnen worden veralgemeniseerd. Voordeel is echter, dat met een geringe investering aan mankracht en middelen een terrein binnen de huisartsgeneeskunde dat tot nu toe in Nederland zowel klinisch als wetenschappelijk weinig aandacht kreeg, in kaart is gebracht, hetgeen uitgangspunt kan zijn voor werder hypothese-toetsend onderzoek.

Duidelijk moge zijn, dat de outillage in de onderzoekspraktijk sterk afwijkt van die welke doorgaans in de Nederlandse huisartspraktijk aanwezig is, terwijl ook de scholing van de huisarts c.q. onderzoeker intensiever is geweest dan die welke de meeste huisartsen doormaakten. Het is daarom niet gerechtvaardigd en ook niet de bedoeling geweest om uitspraken te doen omtrent de aanpak van de Nederlandse huisarts bij oogheelkundige problemen. Voorzover van bewijsvoering sprake is, is dit een indirecte. 
Verondersteld wordt, dat door de aard van de symptomatologie van de verschillende, hier opgespoorde aandoeningen redelijkerwijs mag worden aangenomen dat deze niet kan worden onderkend zonder "optisch sterk" instrumentarium.

Ook zijn kanttekeningen te plaatsen bij de standaard waarmee de diagnosen van de niet verwezen patiënten op hun juistheid werden beoordeeld. De follow-up vormde hierbij het criterium. Contrôle door een oogarts ware wellicht beter geweest, doch hier werd om redenen van uitvoerbaarheid vanaf gezien. Echter, de follow-up vormt dan wel geen "gouden" standaard, maar toch minstens een "goede" standaard, zeker voor die aandoeningen die zonder of met verkeerd ingrijpen zouden zijn verergerd.

Gezien bovenstaande overwegingen is het raadzaam, om de conclusies te beperken tot uitspraken omtrent de omvang en aard van het aanbod aan oogheelkundige problemen in een huisartspraktijk met een doorsnee praktijkpopulatie en omtrent de mogelijkheden om in een dergelijke setting met de nodige investeringen tot een meer gedifferentieerde diagnosestelling en therapeutische aanpak te komen.

Verder onderzoek zou wenselijk zijn, gericht op het effect van training van grotere groepen huisartsen in oogheelkundige vaardigheden en de bijbehorende kennis in de zin vath verandering in opsporing van oogaandoeningen en beleid.

Ook roepen sommige bevindingen vragen op ten aanzien wan het natuurlijk beloop van aandoeningen, zoals fundusafwijkingen bij hypertensie en cataract bij vrouwen. Tot slot verdient onderzoek naar het effect van vroege interventie, zoals bij keratitis herpetica, aanbeveling.

\subsection{Beschouwing en aanbevelingen}

Zoals hierboven reeds aangegeven, zijn, op grond van uit dit onderzoek resulterende bevindingen, twee gevolgtrekkingen te maken die van belang zijn voor de Nederlandse huisarts. De eerste betreft aard en aantal van oogheelkundige problemen in de huisartspraktijk. De aard bleek in dit onderzoek divers, het aantal groot. Er is geen reden te veronderstellen, dat de morbiditeit in andere praktijken sterk hiervan afwijkt. Uit de besproken literatuur en de aard van de oogheelkundige morbiditeits-registraties komt echter een geheel andere indruk naar voren van het oogheelkundig probleemaanbod in de huisartspraktijk.

De tweede conclusie betreft de aanpak van oogheelkundige problemen door de onderzoeker. Deze wijkt af van de doorgaans gebruikelijke. Ten eerste wordt een groot accent gelegd op vroegdiagnostiek, vooral in de vorm van surveillerend onderzoek, ten tweede wordt onderzoek verricht met betere hulpmiddelen. Aannemelijk wordt gemaakt, dat deze wijze van werken in grote mate bepaalt, in hoeverre en in welk stadium bestaande oogaandoeningen worden opgespoord.

Ondanks het ontbreken van een rechtstreeks bewijs voor de meerwaarde van de beschreven aanpak ten opzichte van de doorgaans gebruikelijke, lijkt een pleidooi op zijn plaats voor een andere omschrijving van het kennis- en vaardigheden-pakket voor de huisarts op het gebied van de oogheelkunde en voor intensivering van het onderwijs aan (aanstaande) huisartsen.

De inrichting van het onderwijs in de oogheelkunde, met name in de beroepsopleiding en de nascholing voor de huisarts, lijken in de huidige vorm ontoereikend.

De richtlijnen zoals omschreven in het Basistakenpakket zijn te algemeen van aard om als leidraad woor een adekwate scholing te dienen. Tevens lijken deze te weinig geënt op het morbiditeitsaanbod en op kennis van risico's ten aanzien van verlies van 
gezichtsvermogen. Opmerkelijk is ook, dat refractioneren, een vaardigheid die juist als é̉n wan de moeilijkste geldt, bij de (facultatieve) taken wordt genoemd, terwijl meer toepasbare en eenvoudiger taken ontbreken. Dit doet vermoeden, dat de richtlijnen niet grondig genoeg zijn doordacht.

De huisarts zou gediend zijn met een leerboek oogheelkunde voor de huisarts, dat geënt is op de oogheelkundige morbiditeit in de huisartspraktijk. Dit houdt in, dat met name beginstadia wan aandoeningen worden beschreven. Oogheelkunde is een visueel wak. Goede illustraties, juist van beginstadia van (ernstiger) aandoeningen, zijn daarom wan belang. Deze dienen dan wel overeen te komen met het beeld dat met behulp van het geadwiseerde hulpmiddel wordt verkregen. Belangrijk is ook kennis van de verwijsindicaties naar de oogarts. Het is immers geenszins de bedoeling, dat de huisarts ook oogarts wordt. De huisarts is gebaat bij argumenten voor het vormgeven van een adekwaat beleid en een verantwoorde taakafbakening. Ook adviezen voor aanschaf van apparatuur en praktijkinrichting heeft de huisarts van node. Informatie daarover is op dit moment uiterst schaars.

Vooral de vaardigheden verdienen echter aandacht. Nascholingsbijeenkomsten zouden hier ruim plaats voor moeten inruimen. Een middag oefenen in het omgaan met de spleetlamp of met de indirekte fundoscoop is ontoereikend. Veeleer zijn stages op de polikliniek oogheelkunde, bijvoorbeeld een middag in de week gedurende een half jaar, aan te bevelen. De onderzoeker heeft daar zelf goede ervaring mee opgedaan. Toch is het zelf, dagelijks, oefenen in de eigen praktijk nog de beste leerschool. In Maastricht zijn plannen in voorbereiding voor een intensieve cursus oogheelkunde voor huisartsopleiders met een lease-systeem voor oogheelkundige apparatuur en de mogelijkheid een supervisor te consulteren. Dit lijkt een stap in de goede richting.

In een pleidooi voor verandering van de status quo mag een evaluatie van de kosten-baten-balans niet ontbreken. De huisarts moet immers van vele markten thuis zijn. De oogheelkunde is slechts een onderdeel van het gehele vakgebied. Bovendien mag intensivering van de aandacht voor een bepaald gebied de normale praktijkvoering niet verstoren. De onderzoeker kan hier slechts spreken uit eigen ervaring: naast intensieve scholing in de oogheelkunde hebben ook andere onderdelen van het vakgebied ruim aandacht gekregen, zonder dat dit "naar zijn stellige overtuiging, ten koste ging van overzicht over het totale vakgebied of van de kwaliteit van de huisartsgeneeskundige benadering. Integendeel, verdieping bracht met mame inzicht in de verwevenheid van aandoeningen en in de implicaties ervan op het functioneren van mensen. Ook de praktijkvoering leed geenszins onder de verandering van werkwijze. $\mathrm{Na}$ enige oefening kon nagenoeg elk oogheelkundig consult in de gebruikelijke consulttijd van tien minuten worden afgehandeld. De huisartsen in opleiding in de eigen praktijk bleken allen in staat na enige maanden het gehele oogheelkundig instrumentarium redelijk goed te hanteren.

De financiële investeringen, hoewel niet gering, wogen ruimschoots op tegen het genoegen kennis en ervaring te kunnen vergroten en te benutten.

De onderzoeksresultaten enerzijds en de persoonlijke ervaringen anderzijds geven naar de mening van de onderzoeker steun aan de veronderstelling, dat een betere uitoefening van de oogheelkunde in de huisartspraktijk tot de reële mogelijkheden behoort en de moeite van de getrooste inspanning ruimschoots waard is. 


\section{Samenvatting}

In dit proefschrift wordt verslag gedaan van een onderzoek naar het voorkomen van oogheelkundige problemen in een huisartspraktijk en de benadering daarvan.

In Nederland betreft een aanzienlijk deel van de verwijzingen van ziekenfondspatiënten vanuit de huisartspraktijk naar de specialist verwijzingen naar de oogarts. Desondanks onttrekt het vak oogheelkunde zich steeds meer aan het gezichtsveld van de huisarts. Tot deze slotsom kwam de onderzoeker ettelijke jaren geleden, waarbij hij zich afvroeg wat daarvan de oorzaak was. Een van de mogelijke redenen was de ontoereikendheid van het oogheelkundig instrumentarium van de huisarts, dat aanzienlijk verschilt van dat van de oogarts. Om dit te onderzoeken werd apparatuur op zicht gevraagd en volgden een aantal jaren van intensieve scholing in de oogheelkunde in de vorm van "stages" op twee poliklinieken oogheelkunde, bestudering van literatuur en experimenteren en oefenen met apparatuur.

Gaandeweg werd het oogheelkundig onderzoek in de dagelijkse praktijkvoering geïntegreerd en raakten de patiënten vertrouwd met het idee, dat oogheelkundige problematiek niet zonder meer een verwijzing naar de oogarts inhield. Ook vroeg men de assistentes steeds minder om verwijskaarten voor de oogarts zonder voorafgaand consult door de huisarts. Zodoende ontstond zicht op het oogheelkundige morbiditeitsaanbod.

De behoefte werd gevoeld de eigen ervaring bekendheid te geven en tevens de eigen veronderstellingen omtrent aanbod en aanpak te toetsen. Hieruit ontstond het idee van een proefschrift.

Vertrekpunt was de actuele stand van zaken betreffende het handelen van de Nederlandse huisarts bij oogheelkundige problemen. Bestudeerd werden:

- de richtlijnen voor het handelen van de huisarts bij oogheelkundige problemen zoals gesteld in het Basistakenpakket van de Landelijke Huisartsen Vereniging (1983) en Kenmerken III van van Es, de Melker en Goosmann (1983).

- de verwijscijfers

- het onderwijs in de oogheelkunde

- het wetenschappelijk onderzoek met betrekking tot de oogheelkunde in de huisartspraktijk.

De richtlijnen in het Basistakenpakket en Kenmerken II zijn onderverdeeld in obligate en facultatieve taken, welke alleen in globale termen zijn omschreven.

Het verwijscijfer naar de oogarts is hoog en bedraagt ongeveer een vijfde van het totaal der werwijzingen naar specialisten.

Zowel in de basisartsopleiding als in de beroepsopleiding tot huisarts komt de oogheelkunde slechts summier aan bod.. Ook in de op huisartsen gerichte vakliteratuur komen artikelen betreffende de oogheelkunde weinig voor. Kanttekeningen zijn te maken bij de didactische kwaliteit daarvan. De georganiseerde nascholing biedt instructie betreffende enkele capita selecta. Oefenen in oogheelkundige vaardigheden is daarvan zelden een onderdee].

Het wetenschappelijk onderzoek met betrekking tot het feitelijk handelen van huisartsen bij oogheelkundige problemen is uiterst beperkt. Enig onderzoek is verricht 
naar het oogheelkundig morbiditeitsaanbod en de zinvolheid van screening. De morbiditeitsregistraties van Nijmegen en Lamberts geven de incidentiecijfers betreffende een aantal categorieën van oogheelkundige afwijkingen in de huisartspraktijk weer.

Ook in Engeland en de Verenigde Staten is weinig onderzoek verricht naar het feitelijk oogheelkundig handelen wan huisartsen. De meeste auteurs beperken zich tot slechts eén oogheelkundig onderwerp c.q. aandoening.

Op grond wan deze gegevens werd geconcludeerd, dat allereerst behoefte bestond aan een inventarisatie van het aanbod aan oogheelkundige problemen. Daarnaast wilde de onderzoeker zijn eigen aanpak en het resultaat daarvan aan een nader onderzoek onderwerpen. Vooral het surveillerend onderzoek, gericht op opsporing van potentieel gevaarlijke - oogaandoeningen waarover de patiënt zich niet beklaagde, had daarbij de speciale belangstelling van de onderzoeker.

De volgende onderzoeksvragen werden geformuleerd:

A. Met welk probleemaarbod - in termen van diagnosen op het gebied van de oogheelkunde - werd de huisarts in deze praktijk geconfronteerd?

B. In hoeverre betrof dit diagnosen van belang in het kader van preventie van verminderd gezichtsvermogen?

C. Met welke klachten en/of problemen presenteerden de mensen zich bij wie de bovengenoemde diagnosen werden gesteld?

D. Welke oogheelkundige onderzoekmethoden werden daarbij gebruikt?

E. In welke mate werden de gepresenteerde oogheelkundige problemen door de huisarts zelfstandig afgehandeld dan wel verwezen naar oogarts of opticien?

F. In hoeverre werd de juistheid van de onder A bedoelde diagnosen door de followup bevestigd?

De praktijk waarin het onderzoek werd uitgevoerd, is gevestigd in de oostelijke mijnstreek in Zuid-Limburg. Ten tijde van de uitvoering van het onderzoek werkten de onderzoeker en zijn associe ten behoeve van 4500 mensen. In de praktijk worden tevens huisartsen opgeleid. De samenstelling van de praktijkpopulatie wijkt nauwelijks af van die de van de Nederlandse bevolking. Alleen het aantal vrouwen boven 65 jaar is kleiner.

Gedurende anderhalf jaar werd door de onderzoeker elk oogheelkundig probleem geregistreerd. Er werd naar gestreefd, dat elk oogheelkundig probleem in de praktijk door de onderzoeker zelf werd gezien. De geregistreerde diagnosen waren de diagnosen waarmee de patiënt als het ware "lhet praktijkpand verliet". Deze werden achteraf niet gewijzigd na terugrapportage van de oogarts. Wel werden terugrapportage en follow-up als controle gebruikt voor de juistheid van de gestelde diagnosen.

Ook zogenoemde "negatieve diagnosen" werden geregistreerd: aandoeningen c.q. afwijkingen waarnaar gericht werd gezocht, maar die konden worden uitgesloten.

In anderhalf jaar tijd werden bij 685 personen voor 748 afzonderlijke problemen 910 oogheelkundige consulten verricht. Voor een huisarts met een normpraktijk zou dit 
betekenen, dat deze gemiddeld eenmaal per dag met een oogheelkundig probleem zou worden geconfronteerd. Het aanbod van oogheelkundige problemen kwan met name uit de hogere leeftijdsgroepen. Rekening houdend met de samenstelling van de praktijkpopulatie kwam $25 \%$ van het aanbod uit de leeftijdsgroep van $45-64$ jaar en $30 \%$ uit de leeftijdsgroep van 65 jaar en ouder.

Een kwart van het totale aanbod betrof refractieproblemen, echter de oogproblematiek van personen boven 65 jaar was in ruim $80 \%$ der gevallen van andere aard.

486 problemen werden zelfstandig afgehandeld; 251 problemen werden verwezen: 160 maal naar de opticien, 81 maal (11\%) naar de oogarts en 10 maal naar een andere specialist. Verwijzing naar de oogarts vond 13 maal uitsluitend op verzoek van de patiënt plaats, dus zonder medische indicatie. Follow-up gegevens en terugrapportages van de oogarts leidden tot de conclusie, dat in geen enkel geval een foutieve diagnose van enige klinische relevantie was gesteld.

Het gehele palet aan bekende oogafwijkingen werd gezien. Zeldzame oogafwijkingen kwamen weliswaar afzonderlijk weinig voor, maar hun totaal was relatief hoog en herbergde een niet gering aantal potentieel gevaarlijke aandoeningen.

De verkregen incidenties werden vergeleken met gegevens uit het monitoringproject van Lamberts, de CMR van Nijmegen, en de registraties van Oliemans en Hodgkin. Het meest viel op, dat in het eigen onderzoek een meer gedifferentieerde indeling in categorieën van oogziekten werd gehanteerd en dat een aparte categorie voor fundusafwijkingen bij de andere registraties ontbrak.

In het eigen onderzoek werden refractieproblemen twee tot drie maal vaker geregistreerd. Dit verschil is ten dele te verklaren door het feit, dat aanpassing van een bestaande refractiecorrectie in het eigen onderzoek als "nieuw" werd geregistreerd. Ook glaucoom werd in het eigen onderzoek vaker opgespoord. De incidentie van de groep aandoeningen met als symptoom een "rood oog" waren voor Lamberts, Nijmegen en het eigen onderzoek ongeveer gelijk. Vooral voor deze groep van aandoeningen was het aantal categorieën in het eigen onderzoek veel groter. De relevantie van het gemaakte onderscheid was ondermeer af te leiden uit de differentiatie in de therapie c.q. het beleid.

$\mathrm{Bij}$ de reden voor oogheelkundig onderzoek is onderscheid gemaakt tussen specifieke oogklachten, vage algemene klachten (zoals hoofdpijn, misselijkheid) en aandoeningen met risico voor oogcomplicaties (zoals diabetes en hypertensie). Bij de laatste twee groepen werd het oogonderzoek steeds verricht op initiatief van de arts.

Specifieke oogklachten, 580 maal de reden voor oogonderzoek, betroffen in $83 \%$ van de gevallen klachten over het zien of klachten over pijn aan het oog. Klachten over het zien werden in drie kwart van de gevallen veroorzaakt door refractieproblematiek; cataract kwam op de tweede plaats. Pijn aan het oog werd meestal veroorzaakt door aandoeningen van het voorste oogsegment, waaronder een tiental potentieel gevaarlijk aandoeningen.

Bij vage algemene klachten, 80 maal voor de arts aanleiding tot oogonderzoek, werden in totaal 43 oogafwijkingen aangetroffen. In de helft van de gevallen betrof het refractieproblematiek; tevens werden diverse fundusafwijkingen aangetroffen, waaronder een aantal ernstige.

Aandoeningen met risico voor het oog waren 91 maal reden voor oogheelkundig onderzoek, steeds uitsluitend op initiatief van de arts (surveillance). Daarbij werden in totaal 74 oogafwijkingen geconstateerd, waaronder een groot aantal fundusafwijkingen van diverse aard. 
Bij alle categorieen is het aantal negatieve diagnosen groot, hetgeen wil zeggen, dat vaak gericht gezocht werd naar een (potentieel gevaarlijke) oogaandoening, maar dat deze kon worden uitgesloten.

Bijna alle glaucoompatienten en bijna alle fundusafwijkingen werden opgespoord dank zij surveillerend oogonderzoek.

Elk hulpmiddel dat werd gebruikt voor het oplossen van een oogprobleem werd geregistreerd. In totaal werden 13 werschillende diagnostische hulpmiddelen gebruikt. Het meest frequent werd gebruik gemaakt van de spleetlamp, namelijk in $65 \%$ van de gevallen. In $50 \%$ van de gevallen werd gebruik gemaakt van de indirecte funduscoop en van de visuskaart veraf en in $30 \%$ van de applanatietonometer.

Vaak werden genoemde hulpmiddelen aangewend voor het uitsluiten van ernstiger pathologie.

Met een kwantitatieve applanatietonometer werd 264 maal de oogdruk gemeten. Elf patienten werden voor verdere glaucoomdiagnostiek naar de oogarts verwezen. Daarvan hadden zes personen een glaucoom. Geen van de niet-verwezenen bleek later een glaucoom te hebben. In besliskundige termen betekent dat een sensitiviteit van 1.0 en een specificiteit van 0.98 .

De kans op slechtziendheid en blindheid neemt toe met de leeftijd. Er is een verschuiving opgetreden in de relatieve frekwenties van de oorzaken van blindheid doordat mensen relatief ouder worden (meer maculadegeneratie), diabeten langer leven (meer diabetische retinopathie), en oogaandoeningen eerder worden opgespoord (minder glaucoomblindheid).

In dit onderzoek bleken bij het visusonderzoek van 685 onderzochte personen 15 personen slechtziend/blind aan beide ogen (visus minder dan 0.4) en 40 personen aan één oog.

De afwijkingen verantwoordelijk voor deze slechtziendheid/blindheid waren in eén kwart van de gevallen reeds bekend, werden in de helft van de gevallen ontdekt op geleide van de klacht van de patiënt (klachten over het zien) en in een kwart van de gevallen bij surveillerend oogonderzoek.

Meerdere potentieel gevaarlijke aandoeningen werden opgespoord in een zo vroeg stadium, dat verder verlies van gezichtsvermogen kon worden voorkomen. Tot deze aandoeningen behoorden: diabetische retinopathie, glaucoom, keratitis dendritica, acute uveïtis anterior en amblyopie.

De volgende gevolgtrekkingen werden gemaakt:

De mogelijkheid tot meer gedifferentieerdere diagnostiek van oogaandoeningen resulteerde in een opbrengst aan oogdiagnosen die in hun verscheidenheid bijna het hele palet aan oogafwijkingen uitmaakten. Het tijdig onderkennen van sommige van die afwijkingen was herhaaldelijk bepalend voor de prognose.

Patiënten presenteerden zich voornamelijk met klachten over het zien en met klachten over pijn aan thet oog.

Deze klachten werden weliswaar in het merendeel der gevallen veroorzaakt door respectievelijk refractieafwijkingen en aandoeningen van het voorste oogsegment, maar daarnaast door talrijke andere - deels gevaarlijke - aandoeningen, waarvan de opsporing steeds een grondig oogonderzoek vereiste. In veel gevallen was niet de klacht, maar de wens van de onderzoeker om bepaalde oogafwijkingen uit te sluiten, aanleidling voor de uitvoering van het onderzoek. Dit komt ook tot uiting in een groot aantal zogenoemde "negatieve diagnosen". De in de huisartspraktijk weinig gebruikte 
hulpmiddelen als spleetlamp, indirekte fundoscoop en applanatietonometer werden veelvuldig gebruikt.

Hoewel de onderzoeksopzet niet toelaat te concluderen, dat de opbrengst aan diagnosen mag worden toegeschreven aan het gebruik van genoemde apparatuur en aan de bij de onderzoeker aanwezige kennis, wordt wel aannemelijk gemaakt, dat hier tussen een verband bestaat. Op grond hiervan wordt een aanpassing van de richtlijnen en een intensivering van het onderwijs aan huisartsen op het gebied van de oogheelkunde bepleit. 



\section{Summary}

In this thesis an account is given of research into the prevalence of ophthalmological problems in a general practitioner's practice.

In the Netherlands it was found that a considerable part of the referrals of sick fund patients from the practice of the G.P. to the specialist, were in actual fact referrals to the eye-specialist (ophthalmologist). Notwithstanding all that, the profession of ophthalmology is more and more breaking away from the field of vision of the general practitioner. I came to this conclusion a few years ago and wondered what could be the cause of this phenomenon. One of the reasons might be that the ophthalmological instruments of the G.P. were inadequate, instruments which are quite different from the apparatus used by the eye-specialist. To verify my assumption I had instruments sent to me on approval, subsequently followed by years of intensive education in ophthalmology, in the form of stages at two out-patient departments for ophthalmology, studying literature and experimenting and practising with instruments (apparatus).

Gradually ophthalmologic research was integrated into the daily routine of our practice and our patients became familiar with the idea that if they had an eye problem this does not mean that they are automatically referred to an eye-specialist. Consequently, receptionists in our practice were confronted with ever decreasing requests for referrals to the eye-specialist without previous consultation of the G.P. Thus, a better insight into the ophthalmologic morbidity was obtained.

It was considered necessary to give publicity to the personal experience and at the same time to check the personal assumptions with regard to the approach of ophthalmologic problems. From here the idea of a thesis originated.

Starting point was the actual state of affairs regarding the action taken by the Dutch G.P. when confronted with ophthalmological problems. A detailed study was made

- of the guide-lines for action taken by the G.P. in case of ophthalmologic problems as laid down in the Basistakenpakket (cf. Basic terms of reference) of the National General Practioner's Association (1983) and Kenmerken II by van Es, de Melker and Goosmann (1983).

- Referral statistics

- Education in ophthalmology

- Scientific research with regard to ophthalmology in the G.P.s' practice.

The guide-lines in the Basistakenpakket and Kenmerken II are subdivided into obligatory and optional tasks, which are only described in broad terms.

The rate of referrals to the eye-specialist is high and amounts to approximately onefifth of the total number of referrals to specialists.

Both in the basic training for G.P. and in the vocational training for G.P., ophthalmology is only very briefly touched. Even in the specific technical literature for G.P.'s, articles related to ophthalmology but little occur. The didactic standard of this 
training calls for comment. The organised refresher courses provide instruction concerning some capita selecta. The actual practising in ophthalmological skills is seldom included in the curriculum.

There has been very little scientific research into the ways G.P.'s actually tackle ophthalmological problems. Some research into the ophthalmological morbidity and the significance of screening has been conducted. The morbidity registrations of Nijmegen and Lamberts clearly picture incidence figures with regard to a number of categories of ophthalmological diseases in the G.P.s" practice.

Even in England and the United States little research was conducted into ophthalmological treatment by G.P."s. Most authors restrict themselves to only one ophthalmological subject c.q. disease.

On the ground of these data I concluded that first of all there was a need to take an inventory of the total number of ophthalmological problems. In addition I wanted to make further inquiries into my own approach and the result of that approach. Particularly the surveilling examination focused on the detection of potentially dangerous eye diseases about which the patient did not complain, deserved my special attention.

The survey was carried out to provide answers to the following questions:

A What problems did this G.P, have to face in his own practice in terms of diagnosis of eye diseases.

B. What percentage of these diagnoses were of importance with regard to prevention of reduced power of vision?

C. What were basically the complaints expressed to the doctor who made the above diagnoses?

D. Which methods of research were used for the ophthalmological examination?

E. To what extent did the G.P. deal with the problems himself or refer the patient to the ophthalmologist or the optician?

F. What percentage of the diagnoses under A were confirmed during follow-up?

The practice in which the research was conducted, is located in the eastern miningdistrict of South-Limburg. During the research period the researcher and his partner worked for a population of 4500 people. In this practice there is also a training for G.P.'s. The built-up of these 4500 people is largely similar to that of the overall Dutch population; except for the number of women over 65 , which is below average.

For 18 months each ophthalmological problem was registered by drawing up a report of the consultation. The intention was that every patient with an eye problem was seen by the researcher. The registered diagnoses were those made before the patient left the premises. They were never changed afterwards on receipt of the ophthalmologist's report although feedback and follow-up were used to check the accuracy of the diagnoses made. 
Negative diagnoses were also registered, in other words I did register cases where I looked specifically for certain diseases c.q. abnormalities but these could subsequently be excluded.

In a period of eighteen months 910 ophthalmological examinations were carried out involving 685 patients with 748 individual problems. For a G.P. with a standard practice this would mean that on average he would be confronted with an ophthalmological problem once a day. The total number of ophthalmological problems mainly occurred in the higher age brackets. Taking into consideration the built-up of the practice population, 25 per cent of the total occurred in the age brackets $45-64$ years and 30 per cent in the age bracket 65 years and over.

A quarter of the total number of ophthalmologic problems in my practice related to refractive errors, however, the eye problems of persons over 65 years of age was in more than 80 per cent of the cases of a different nature.

486 cases were treated in our own practice; 251 were referred: 160 to the optician, $81(11 \%)$ to the ophthalmologist and ten to another specialist. Referral to the ophthalmologist took place 13 times exclusively at the request of the patient, so without medical indication. Follow-up data and feed back reports of the ophthalmologist led to the conclusion that no wrong diagnosis of any clinical relevance was made.

The patient's complaints covered the entire range of known eye abnormalities. Rare eye abnormalities however, occurred - separately - in only a few cases, but their total number was relatively high and included a fair number of potentially dangerous diseases.

The incidences thus obtained were compared with data from the monitoring project of Lamberts, the continuous morbidity registration of Nijmegen, and the registration of Oliemans and Hodgkin. The most striking aspect was that in my own research a more differentiated categorisation of eye diseases was used and that a separate category for fundus diseases was lacking in the other surveys.

In my own research, refractive errors were registered two to three times more often. This difference is partly attributable to the fact that adjustment of an existing refraction correction in my own research was registered as new. Even glaucoma was more often detected in my own research. The incidence of the group diseases with the red eye symptom was practically the same for Lamberts, Nijmegen and my own research. Particularly for this group of diseases the number of categories in my own research, was considerably larger. The relevance of this distinction made could be deducted from the differentiation in therapy and/or the approach.

Before starting an ophthallmological examination, I made a distinction between specific eye complaints, vague general complaints (such as headache, nausea) and diseases with risk of eye complications (such as diabetes and hypertension). In the last two categories eye examination was always conducted at the initiative of the G.P.

Specific eye complaints (troubles) which were the reason for eye examination in 580 cases, had to do with reduced vision or complaints about pain in the eye in 83 per cent of the cases. $75 \%$ of the complaints about reduced vision were caused by refraction problems; cataract came second. Pain in the eye was mostly caused by affections of the anterior segment of the eye, among which I found nine or ten potentially dangerous diseases. 
In vague general complaints the G.P. in 80 cases decided to have an eyeexamination, in 43 out of the 80 cases he found eye-abnormalities. In 50 per cent of the cases this had to do with refraction problems; likewise various fundus abnormalities were found, some of them serious.

In 91 cases, diseases with risk of eye complications called for ophthalmologic examination always exclusively at the initiative of the doctor (surveillance). The examinations resulted in a total of 74 eye-abnormalities among which a great number of fundus abnormalities of various nature.

There were many negative diagnoses in all categories which implies that often we looked specifically for symptoms of a (potentially dangerous) eye disease which could subsequently be excluded.

Nearly all glaucoma patients and nearly all fundus abnormalities were detected thanks to the surveying eye examination.

Each aid used to try and solve an eye problem was registered. In total 13 different diagnostic aids were used. In most cases - 65 per cent - the slitlamp was used; in 50 per cert the indirect ophthalmoscope and the vision chart, in 30 per cent the applanationtonometer. These instruments were often used to exclude more serious pathology.

By means of a quantitative applanationtonometer intraocular eye pressure was taken 264 times. Eleven patients were referred to the ophthalmologist for further glaucoma diagnosis; six of them appeared to have a glaucoma. None of the nonreferred patients later appeared to have a glaucoma. In terms of clinical decision this means a sensitivity of 1.0 and a specificity of 0.98 .

The chance of poor vision and blindness increases with age. There has been a change in the relative frequencies of the causes of blindness because of people getting relatively older (more macular degeneration), diabetics live longer (more diabetic retinopathy) and eye-diseases are detected sooner (fewer cases of glaucoma blindness).

We examined the eye-sight of 685 patients and found that 15 patients were blind or had poor vision in both eyes (vision less than 0.4 ) and 40 patients blind/poor vision in one eye.

The abnormalities that caused this blindness/poor vision were already known in 25 per cent of the cases; in 50 per cent they were discovered on the basis of the patient's complaints about eye sight and in another 25 per cent they were diagnosed during the surveying eye-examination.

Several potentially dangerous diseases were detected so early that further loss of eye-sight could be prevented. These diseases were: diabetic retinopathy, glaucoma, dendritic keratitis, acute anterior uveitis and amblyopia.

The following conclusions were drawn:

Owing to a greater variety in diagnostics of eye-diseases, we diagnosed so many different eye-diseases that nearly the entire range of eye-abnormalities was covered. The early diagnosis of some of these abnormalities was repeatedly the determining factor for the prognosis.

Patients mainly came to the G.P. complaining of reduced eye-sight and pain in the eye.

Although most of these complaints were attributable to refraction errors and abnormalities of the anterior segment of the eye, many others were caused by abnormalities - some of which dangerous - whose detection always required thorough 
eye-examination. In many cases it was not the patient"s complaint which induced me to start the eye-examination but my own wish to exclude specific abnormalities. This is also reflected in a large number of negative diagnoses. We often applied aids that are little used in a G.P.s" practice e.g. slitlamp, indirect ophthalmoscope and applanationtonometer.

Although the concept of my research method does not allow the conclusion that the total number of diagnoses should be attributed to the use of the said instruments and the existing expertise of the researcher, it sounds quite plausible to assume that these elements have actually played an important part. I would therefore recommend that the existing guide-lines be adjusted and that the professional education of G.P.'s in the ophthalmologic field be intensified. 



\section{Literatuur}

Bain DJ. Methods used by general practitioners in developmental screening of preschool children. $\mathrm{Br}$ Med $J$ 1977; 2: 363.

Baggen JL, Vaessen MHJ, Jacobs JPL. De diabetespatient: dokter is er zoet mee. Med Contact 1986; $41: 704$.

Baggen JL. Keratitis dendritica in een huisartspraktijk. Ned Tijdschr Geneeskd 1985; 129: 2213 en 1986; 130: 131 en 1033.

Beek G van de, Schiffelers HRM. Enquete oogspiegelen in de huisartspraktijk. Skillslab Rijksuniversiteit Limburg 1982. (niet gepubliceerd).

Braam HAL. Een overzicht van veel voorkomende oogheelkundige afwijkingen in de geriatrie. Moderne Geriatrie jan 1984: 9.

Breebaart AC. Omvang en oorzaken van blindheid in de wereld. Ned Tijdschr Geneeskd 1983; 127: 877.

Bouhuys PAJ. Nascholing huisartsen. Onderwerpen voor regionale nascholingscursussen. Wat vindt de huisarts er zelf van? Med Contact 1981; 36: 599.

Bosch WJHM van den. Herpesvirusinfecties in de huisartspraktijk. Patient Care (ned ed) mei 1986: 15 .

Bulger JTh. Oogaandoeningen: behandelen, consulteren, verwijzen? Patient Care (ned ed); febr 1981: 24 .

Bremer GJ. Het oogheelkundig onderzoek in de huisartspraktijk. Huisarts en Wetenschap 1970; 13: 181.

Bijsterveld OP van, Post HJ. Trifluorothymidine and adenine arabinoside in the treatment of dendritic keratitis. In: Sundmacher R (red). Herpetische Augenerkrankungen. München: J.F. Bergmann Verlag, 1981.

Bijsterveld OP van, Ekdom B. Het rode oog; diagnostiek en behandeling van conjunctivitis. Ned Tijdschr Geneeskd 1987; 131: 2251.

Claque CMP, Stevenson KE. Incidence of inappropriate treatment of herpes simplex keratitis with topical steroids. Br Med J 1986; 292: 1450.

Colenbrander MC. Gevaar voor de ogen door langdurig gebruik van corticosteroiden. Ned Tijdschr Geneeskd 1971; 115: 435. 
Crone RA. Amblyopie. Ned Tyjschr Geneeskd 1972; 116: 789.

Crone RA. Een alledaagse ziekte. Bespiegelingen over de voorhoedefunctie van de academische ziekenhuizen. Ned Tijdschr Geneeskd 1977; 121: 1193.

Collins EC, Eagan EF, Payseur GS. Wenken voor de tijdige opsporing van glaucoom. Patient Care (ned ed); maart 1977: 22.

I'Espoir NEJC, Snellen-Balendong HAM, Bouhuys PAJ, Metsemakers JFM. Onderzoek van Onderwijs. Rijksuniversiteit Limburg 1988.

Es JC van, Melker RA de, Goosmann FCL. Kenmerken van de Huisarts II. Bohn, Scheltema \& Holkema, Utrecht/ Antwerpen 1983.

Doesschate $J$ ten (a). Causes of blindness in the Netherlands. Doc Ophth 1982; 52: 279.

Doesschate J ten (b). Causes of blindness in the Netherlands. Doc Ophth 1982; 52: 3.

Fielder AP. De zuigeling die niet goed lijkt te zien. The Practitioner (ned ed); sept 1985: 915.

Goudsmit $\mathbb{J}$, Noordaal $\mathbf{J}$ van der. Antiherpetica en hun indicaties. Ned Tijdschr Geneeskd 1983; 127: 597.

Gunn RM. Ophthalmoscopic evidence of arterial changes associated with chronic renal disease, and of increased arterial tension. Trans Ophth Soc U.K. 1904; 24: 356.

Gifford RW. The Importance of retinal findings in essential hypertension. Bull NY AC Med 1969; 45: 922.

Hagedoorn A. Strabismus. Ned Tijdschr Geneeskd 1968; 112: 1557.

Hagedoorn A. Interne geneeskunde en oogheelkunde. Ned Tijdschr Geneeskd 1963; 107: 696 .

Hodgkin K. Towards earlier diagnosis in primary care. Churchill Livingstone. Edinburgh, London, New York, 1978.

Henkes FIE, Balen AThM van. Oogheelkunde. Elsevier Amsterdam/ Brussel 1983.

Henkes HE. Indicaties en contra-indicaties voor het gebruik van corticosteroiden in de oogheelkunde. Ned Tijdschr Geneeskd 1977; 121: 1605.

Howie JGR, Tayler JL. Raised intraocular pressure. Time for a rethink on referral procedure? B Med J 1982; 285: 1009. 
Kar van de. Een onderzoek naar de waarde van de fundusfotografie bij het opsporen van diabetische retinopathie in de huisartsenpraktijk. Krips Repro Meppel, 1988.

Karmal A, Gummerus S, Kujansuu E, Pitkajarvi T. Detection of diabetic retinopathy in primary health care. WONCA London 1986.

Kanski JJ. Diabetische retinopathie. The Practitioner (ned ed); sept 1985: 905.

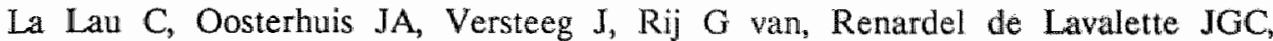
Craandijk A, Lamers WRMJ, Mierlobensteyn Th. Aciclovir and trifluorothymidine in herpetic keratitis. Preliminary report of a multicentered trial. Doc Ophth 1981; 50: 287.

Lamberts H. Morbidity in General Practice. Uitgeversmij Huisartsenpers BV. Utrecht, 1984.

Lamers WPMA. Taakverdeling oogarts - huisarts. VAGZ Magazine 1986; 2: 8.

Landelijke Huisartsen Vereniging. Basistakenpakket van de Huisarts. 1983.

Landelijke Huisartsen Vereniging. Wijziging/ aanpassing dd ?? 26-11- 1985 .

Nolet HA, Prick- Slothouwer NFA. Cataract, een blinde vlek? Huisarts en Wetenschap 1978; $21: 97$.

Nijmeegs Universitair Huisartsen Instituut. Morbidity figures from general practice. Data from four general practices 1979 - 1982. N.U.H.I. 1985.

NIVEL. Een nationale studie naar ziekten en verrichtingen in de huisartspraktijk. Terugrapportage periode 2. 1987.

Oliemans AP. Morbiditeit in de huisartsenpraktijk. HE Stenfert Kroese NV. Leiden 1969.

Oosterhuis JA. Vaatafwijkingen in het oog bij diabetes. Ned Tijdschr Geneeskd 1984; 128: 1567.

Perloff $\mathrm{D}$, Sokolow $\mathrm{M}$, Cowan $\mathrm{R}$. The Prognostic value of ambulatory blood pressures. JAMA 1983; 249: 2792.

Post D. LISZ - gegevens en ziekenfonds - eigen informatie voor beoordeling van oogartsproductie. VAGZ Magazine 1986;130: 2367.

Post D. Verwijzen naar de oogarts. Patient Care (ned ed) aug 1989.

Price M, Philips CI. A general practitioner in an ophthalmology accident and emergency departement. Br Med J 1976; 2: 509. 
Reitsma WD. Diabetescontrole en late complicaties. Ned Tijdschr Geneeskd 1985; 129: 989.

Rens JWGA van. Glaucoma Simplex in de huisartspraktijk Bohn, Scheltema \& Holkema, Utrecht 1976.

Rijksuniversiteit Limburg. Faculteit der Geneeskunde. Ondenwijsverslag 1987.

Smit PTh. De huisarts en het "kJeine" vak oogheelkunde. Patient Care (ned ed) maart 1.986: 2.

Steinmann WC. The "who" and "how" of detecting glaucoma. Br Med J 1982; 285: 1091.

Sturmans F. Epidemiologie. Dekker \& van de Vegt Nijmegen, 1986.

Scheie HG. Evaluation of ophthalmoscopic changes of hypertension and arteriolar sclerosis. Archs Ophth N.Y. 1953; 49: 117.

Schweitzer NMJ. Het onderzoek van de ogen. In: Bremer en Hoekstra (red). Anamnese en onderzoek in de huisartspraktijk. Wetenschappeilijke uitgeverij; Utrecht 1986.

Tan LHC. Tekorten in de opleiding tot huisarts. Proefschrift Universiteit van Amsterdam, 1989.

Tielens VCL, Mokkink H, Mesker P. Het medisch - diagnostisch handelen van de huisarts. Huisarts en Wetenschap 1985; $28: 44$.

Tucker JB. Glaucoma detection in family practice. I Fam Pract 1981; 12: 565.

Weel Chr van. Diabetische retinopathie. Huisarts en Praktijk 1979; 3: 18.

Wilson A. The red eye: a general practice survey. I Royal Coll Gen Practitioners 1987; 37: 62 .

Wolfhagen I. Programma-evaluatie PMO-H. Overzicht van de resultaten 1987-1988. Rijksuniversiteit Limburg, 1988. 


\title{
Wijzigingen/aanpassingen Basistakenpakket dd 26-11-1985 Facultatieve taken.
}

\author{
Hoofdstuk $\mathbf{F}$ \\ Brillen aanmeten en oogheelkundig onderzoek
}

Een bril kan door de huiarts in beginsel worden aangemeten wanneer, met uitsluiting van andere oogpathologie, door middel van refractiecorrectic een wisusverbetering iot (nagenoeg) $100 \%(5 / 5) \mathrm{kan}$ worden bereikt. Daarom mag het aanmeten ban brillen slechts dan in de eerste lijn plaatsvinden, wanneer daar tevens het vereiste oogheelkundig onderzoek kan plaatsvinden.

Visusbepaling en refractioneren zijn technisch gesproken niet moeilijk, maar vereisen nauwkeurigheid, geduld, systematisch werken on weel ervaring.

Dit geldt net name bij jonge kinderen, waturbij het uitsluiten van o.a. (latent) strabisme wan groot belang is en meer onderzoekservaring vergt dan in een doorsnee huisartspraktijk te verwerven valt. Daarom valt aan te raden (jonge) kinderen geen brillen aan te meten zonder voorafga ande specialistische diagnostiak.

\section{Indicatiegebied}

Volwassenen met klachten over het nabij zien of in de verte zien,

- objectiveerbare/ reproduceerbatre visuswermindering

- korrigeerbaar tot $100 \%$ met positieve resp. negalieve sferische glazen, eventueel met toevoeging van een kleine cylinder $(1 / 2-1)$

- afwezigheid van andere pathologie.

Volwassen brildragers bij wie in het verleden een relractie-afwijking is vastgesteld en warbij na verloop van tijd kleine aanpassingen van de brilsterkte noodzakelijk blijken om een volledige korrektie te bereiken (bijw. bij lichte myopie, presbyopie).

\section{Deskundigheidsbevordering en -bewaking}

1. Uitsluiten andere pathologie

Bij kinderen: in het algemeen indicatie woor verwijzing

Bij wolwassemen:

1. algemeen uitwendig onderzoek

2. inspektie media met spleetlampje en een loupe (corneatroebeling, cormeadefecten, VOK- toebeling, lensafwijkingen)

3. ophthalmoscopie: glaswochtafwijkingen, netvliesafwijkingen, watafwijkingen, papilafwijkingen

4. oogboldrukmeting

5. gezichtsveldbepaling (oog- in- oog methode)

De vereiste deskundigheid is te werwerven door studie (lecrboek), door het opdoen van ervaring, waartoe iedere huisartsempraktijk ruimschoots gelegenheid biedt, en woor zover nodig door training onder supervisic wan ervaren deskundige. (met name: ophthalmoscopie, oogboldrukmeting).

Epidemiologisch belangrijke pathologie:

- cataract (lenstroebelingen)

- ablatio retinae

- verhoogde oogboldruk/glaucoom (tonometrie, gezichtsveldafwijkingen, randstandig vaatwerloop/ excavatie - netvliesafwijkingen tgv hypertensie, diabetes, art. sklerose)

- VOK- traebeling is met een loupe + spleetlampje niet altijd wit te sluiten, maar epidemiologisch alleen van belang bij br rheuma en Besnier Boeck paticntem: bij pupilverwijding letten op synechien. 
2. Refractioneren: essentied is crvaring (letten op reaktie san patient, tempo anpassen ) en geduld, daarmaast systematiek (beginnen met positieve glazen, daama negatieve, zonodig cylinders). Refractioneren is primair van belang on de corrigecrbaarheid vast te stellen.

\section{Errvaring}

Ervarimg is van doorslaggevend belang. De gemiddelde proktijk biedt - gelet op het indicatiegebied rumachoots gelegenheid on die ervaring te verwerven. Van alle verwijzingen naar de oogarts gaat $60 \%$ am refractieproblemen.

\section{Uitrusting}

Letterkaart (Snellen of Landoltringen)

Leestekst- kaart woor nabij zien

Montuur + glazen (sferisch van mogelijkheden +5 tor -5 , interval $1 / 2$, cylindrisch tot 2, Maddox glas)

Binoculaire loupe

Ophithalmoscoop met splectlampje

tonometer Schiotz of glaucotest

fluresceine strips

cornea- anesteticum

\section{Konklusie}

De meeste refractieproblemen bij volwassenen kunnen door de huisarts worden behandeld. Deskundigheid is in principe makkelijk te verwerven, de praktijk biedt voldoende garantie voor het onderhouden daarvan en voor bet opdoen van ervaring. Bij voldoende deskundigheid, geduld en de beslissing om middels feitelijke toepassing de ervaring te onderhouden ${ }_{n}$ kan dit als facultatieve taak door huisartsen worden uitgevoerd.

Refractie- korrektie bij jonge kindren vereist zeer veel ervaring mbt het uitsluiten van andere pathologie. Ondat de doorsnee huisartsenpraktijk daarvoor te klein is, kan dit in principe geen facultatieve taak zijn. 


\section{Bijlage II}

\section{Kenmerken van de huisarts II: de drie kennis- en vaardighedennivos van de huisarts op het gebied van de oogheelkunde}

In Kenmerken van de Huisarts II (van Es, de Melker, Goosmann 1983) worden drie kennis- en vaardighedennivos van de huisarts onderscheiden.

nivo 1: ziekten die de huisarts zelfstandig moet kunnen diagnostiseren en behandelen. Dat zijn voor de oogheelkunde:

conjunctivitis

blefaritis

hordeolum

niet perforerend corpus alienum

refractieafwijkingen (alleen sferisch en presbyoop).

lasogen

nivo 2: ziekten die de huisarts in zijn differentiaaldiagnose moet kunnen opnemen en na overleg met de oogarts zelf afhandelen. Dat zijn:

dacryostenose

dacryoflegmone

entropion

blindheid

chalazion

keratoconjunctivitis

glaucoom

nivo 3: ziekten die de huisarts in zijn differentiaaldiagnose moet kunnen opnemen waarbij hij/zij moet kutuen aangeven in hoewerre deze "pluis" dan wel "niet-phis" zijn. Dat zijn:

keratitis (imd K Dendritica)

iritis

ontsteking $N$ Opticus en retina

ontsteking traanwegen

refractieafwijkingen

cotneatroebeling

strabismus

cataract

retinaziekten ind ablatio

uveitis

exophthalmus

oogspierparese

hemianopsic

plotseling optredend vermindering gezichtsvermogen

oogletsels. 



\section{Computerformulier}

computertormulier rubrieken ougheelkunde
in een huisartspraktijk

patientenumer

datum

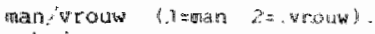

geb jaar

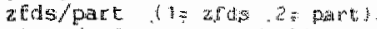

eigen/indermans praktijk. (h= eigea 2 andenans wat

$-\ldots-\ldots \ldots-\ldots$

soort wan het eerste consult

kentrerken patiënt:

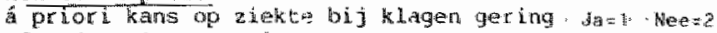

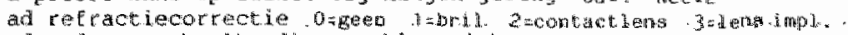
ad andere ooghed lkundige problemati id

ad kenmerken op niet-oogheelkundige gebíd maar wel relevant voor de oogheelkunde

hypertensite ifla $2=$ Nee diabetes. 1sug $2=$ Nee

voorgeschiedenis $v_{\text {cardiovas }}$ accident $1_{n}=4 a, 2=$ Nee andere afwijkingen/ziekten

$$
\text { 11:ula } 2 \text { inee }
$$

patiënt is reeds onder behandeling/controle van oogarts, $1=$ Ja opticiên' tal andere specialist. 1? Jal

oogheelkundig onder zoek op initiatief var:

- - - - - - - - - - - - - - - - - - - - de klacht betreft één/twee ogen: 1. 2 .

reden van oogheelkundig onder zoek:

specitieke oogklachten

ad wage algamene klachten

bestaande afwi jkingen met $r$ isico vam het oog

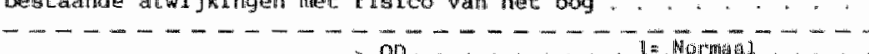

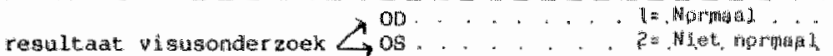

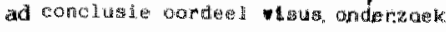

ad oogstand en oog beweglngen

ad oogleden

ad klieren halsgebied

ad traanwegen

ad conjunet iva

ad cornea

ad sclera

acil unea

ad lens

ad corpus vitreum

ad fundus bij hypertensie

ad fundus bij ai abetes

ad fundus t.a.v. arteriolosclerose

ad fundus bij andere vatpathologie

ad retinal.
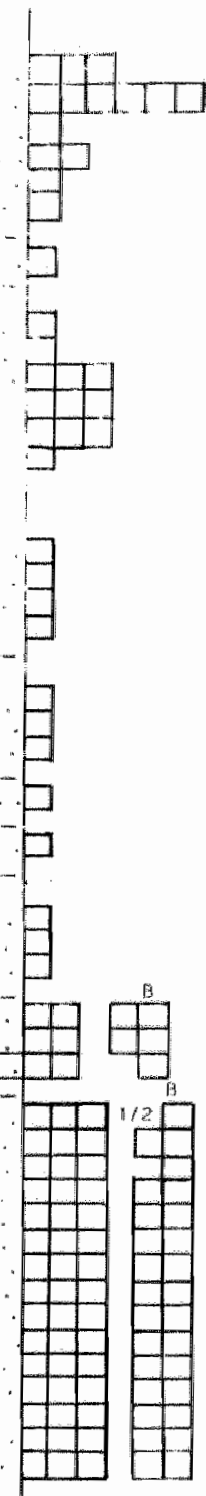


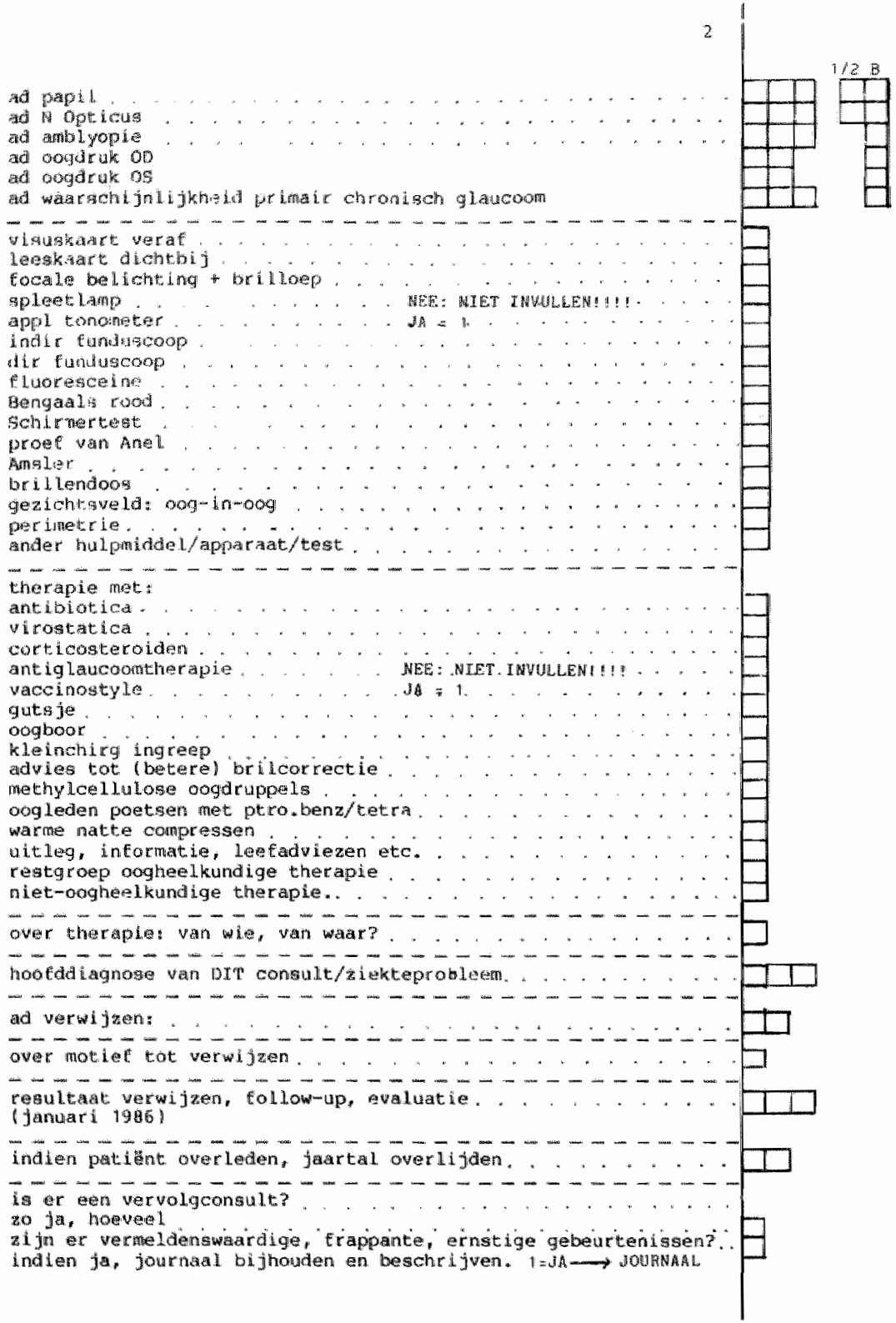




\section{Bijlage IV}

\section{Rubriekenlijst}

$\mathrm{B}=$ soort bevinding

$1 / 2=$ ecn of twee ogen

visus $O D$ in decimalen

00

visus $O S$ in decimalen

00

Conclusie/oordeel visusonderzoek

230 geen visuswermindering; indien

000

gecorrigeerd, dan goed gecorrigeerd

240 visusafw tgv refractieafw

241 myopie

242 hypermetropie

243 presbyopie

244 astigmatisme

245 gecompliceerde refracticafis

246 myopia gravis

250 visusafw niet tgv refr afw

Oogstand en oogbewegingen

000

$1 / 2 \quad B$

001 geen afwijkingen

002 (mogelijk)(latent) strabismus

003 strabismus paralyticus

004 amblyopie inet/zonder strabismus

005 nystagmus

006 exophithalmus

007 andere afwijking

Oogleden

010 geen afwijkingen

$000 \quad 0 \quad 0$

011 summiere afwa;geem diagnose te stellen

012 wratje

013 chalazion

014 hordeolum

015 blefaritis

016 kalkconcrementen

017 trichiasis

018 herpesinfectie

019 oedeem

020 neurodermitis

021 entropion

022 ectropion

023 restgroep

Klieren halsgebied

030 geen klieren palpabell

031 klieren palpabel 
040 geen afwijkingen

041 niet atuliggende traanpunten

042 verstopte afwoer traanwegen

043 verminderde traanproductie

044 dacryocystitis

045 resilgroep

Corjunctiva

050 geen afwijkingeri

051 summiere afwn; geen diagnose te stellen

052 subconjunctivale bloeding

053 bact conjunctivitis (waarschijnlijk)

054 ophihalmia neonatorum

055 vir follic conjunctivitis (waarschijnlije)

056 conjunctivitis vernalis

057 hooikoorts

058 corpus alienum

059 pinguecula

060 pingueculitis

061 plerygüm

062 tumor

063 restgroep

Cornea

070 geen afwijkingen

$000 \quad 0 \quad 0$

071 keratitis dendritica

072 keratitis discoides

073 keratitis marginalis

074 keratitis electrica

075 erosie

076 corp al/ roestring

077 macula corneae

078 corneapigmentaties

079 valatingroei

080 corneaoedeem

081 keratitis punctata

082 restgroep

Sclera

090 geen afwijkingen

$000 \quad 0 \quad 0$

091 episcleritis

092 restgroep

Uvea

100 geen afwijkingen

$000 \quad 0 \quad 0$

101 ac uveitis ant

102 chr uveitis ant

103 ac uveitis post

104 chr uveitis post

105 lasercoagulaten

106 restgroep 
Lens

110 geen afwijkingen

111 in geringe mate cataract

112 seniel catarract

113 toxisch cataract

114 diabetes cataract

115 congenitaal cataract

116 traumatisch cataract

117 anderszins cataract

118 afakie

119 lensimplantaat

120 restgroep

Corpus vitreum
130 geen afwijkingen
131 glaswochtmembraanlloslating
132 verdichte structuur, troebelingen
133 sinchisis scintillans.
134 bloedingen
135 persisterende $A$ hyaloidea
136 restgroep

Fundus bij hypertensie

140 geen fundus hypertonicus

$000 \quad 0 \quad 0$

141 nauwe arteriolen/ wijde venen

142. met bloedingen

143 met cotton wools

144 met papiloedeem

Fundus bij diabetes

150 geen diabetische retinopathie

00000

151 instens ến microaneurysma

152 bloedingen en exsudaten

153 prolifer veranderingen, glaswochtbloedingen

Fundus bij arteriolosclerosis

$000 \quad 0 \quad 0$

160 geen arteriolosclerosis

161 bij overkruising vene niet transparant

162 idem indrukken veneuze bloedkolom

163 idem puntwormig ingedrukte veneuze bloedkolon; zilverdraadarteriolen

164 veneuze stuwing; takafsluiting VCR

Fundus bij andere vatpathologie

$000 \quad 0 \quad 0$

171 andere vaatpathologie

Retina

180 geen afwijkingen

$000 \quad 0 \quad 0$

181 geringe pigmentafw in maculat

182 maculadegeneratie

183 veell Drusen in periferie

184 veel Drusen in macula

185 ablatio retinae

186 restgroep 
Papil

190 geen afwijklingen

191 bleke papil

192 papiloedeem

193 peripapillaire atrofie

$194 \mathrm{C} / \mathrm{D}$ verdachi voor glaucoom

195 resigroep

N Opticus

201 (mogelijk) neuritis optica

000

00

202 (mogelijk) opticusatrolie

Amblyopie

000

210 geen amblyopie

211 amblyopie

Oogdruk $O D$ in $\mathrm{mmHg}$

Oogdruk OS in mmHg

Glaucoom

220 waarschijnlijk geen pr chr glaucoom

221 misschien pr chr glaucoom

222 waarschijnlijk pr chr glaucoom

223 secundair glaucoom

Therapie: van wie, van waar

1 nu nieuw

2 herhaling eigen receptwur

3 herhaling receptuur oogarts

Hoofddiagnose van dit consult/probleem

toelichting:

de code 000 werd gebruikt bij het constateren van

gến oogafwijkingen

Verwijzen

00 niet ter zake; reeds onder behandeling

10 niet verwezen

21 naar de oogarts

22 naar de opticien

23 andere specialist

Motief tot verwijzen

1 = terecht naar mijn mening

2 sonterecht naar mijn mening

Resulat verwijzen, follw-up, evaluatie

110 niet verwezen mijn diagnose bevestigd

120 niet verwezen; ik twijlel aan mijn juiste diagnose

121 niet verwezen; ik heb twijlels over mijn beleid

130 niet verwezen; beloop niet te achterhalen

210 wel verwezen; diagnose congruent met mijn visie

220 wel verwezen; de ander heeft een andere visic niet in de orde van juist/ onjuist

221. wel verwezen; door mij te licht ingeschat

222 wel verwezen; door mij te zwaar ingeschat

230 wel verwezen; beloop niet te achterhalen 


\section{Incidentielijst}

\begin{tabular}{|c|c|c|c|c|c|c|c|c|c|c|}
\hline \multirow[b]{2}{*}{ Aandoening } & \multirow{2}{*}{$\begin{array}{c}\text { Nieuw- } \\
\text { Oud }\end{array}$} & \multirow[b]{2}{*}{ Sexe } & \multicolumn{6}{|c|}{ Leefijdscategorie } & \multirow[b]{2}{*}{ Totaal } & \multirow{2}{*}{$\begin{array}{l}\text { Inci- } \\
\text { dentio }\end{array}$} \\
\hline & & & $0-4$ & 5.14 & $15-24$ & $25-44$ & $45-64$ & $\geq 65$ & & \\
\hline \multirow{6}{*}{$\begin{array}{l}\text { Refractic- } \\
\text { afwijkingen }\end{array}$} & Nieuw & Man & & 11 & 5 & 15 & 34 & 11 & 76 & 22.5 \\
\hline & & Vrouw & & 8 & 9 & 23 & 56 & 19 & 115 & 34.0 \\
\hline & & Totaal & & 19 & 14 & 38 & 90 & 30 & 191 & 28.3 \\
\hline & Oud & Man & & & & & & & & \\
\hline & & Vrouw & & & & & & & & \\
\hline & & Totaal & & & 1 & & & & 1 & \\
\hline \multirow{5}{*}{$\begin{array}{l}\text { Latent } \\
\text { Strabisme }\end{array}$} & Nieuw & Man & & & & & & & & \\
\hline & & Vrouw & & & & & & & & \\
\hline & & Totaal & 1 & & & & & & 1 & 0.1 \\
\hline & Oud & Man & & & & & & & & \\
\hline & & Totaal & & & & & & & & \\
\hline \multirow[t]{5}{*}{$\begin{array}{l}\text { Strabismus } \\
\text { paralyticus }\end{array}$} & Nieuw & $\begin{array}{l}\text { Man } \\
\text { Vrouw }\end{array}$ & & & & & & & & \\
\hline & & Totaal & & & & & $\mathbb{1}$ & & 1 & 0.1 \\
\hline & Oud & Man & & & & & & & & \\
\hline & & Vrouw & & & & & & & & \\
\hline & & Totaal & & & & & & & & \\
\hline \multirow[t]{6}{*}{ Strabismus } & Nieuw & Man & & & & & & & & \\
\hline & & Vrouw & & & & & & & & \\
\hline & & Tolaal & 2 & & & & & & 2 & 0.3 \\
\hline & Oud & Man & & & & & & & & \\
\hline & & Vrouw & & & & & & & & \\
\hline & & Totaal & & & & & & & & \\
\hline \multirow[t]{6}{*}{ Exophthalmus } & Nieuw & Man & & & & & & & & \\
\hline & & Vrouw & & & & & & & & \\
\hline & & Totaal & & & & 1 & & 1 & 2 & 0.3 \\
\hline & Ond & Man & & & & & & & & \\
\hline & & Vrouw & & & & & & & & \\
\hline & & Totaal & & & & & & & & \\
\hline \multirow[t]{6}{*}{ Wratje } & Nieuw & Man & & & & & & & & \\
\hline & & Vrousw & & & & & & & & \\
\hline & & Totaal & & & & & 1 & 1. & 2 & 0.3 \\
\hline & Oud & Man & & & & & & & & \\
\hline & & Vrouw & & & & & & & & \\
\hline & & Totaal & & & & & & & & \\
\hline
\end{tabular}




\begin{tabular}{|c|c|c|c|c|c|c|c|c|c|c|}
\hline \multirow[b]{2}{*}{ Aandoening } & \multirow[b]{2}{*}{$\begin{array}{l}\text { Nieuw- } \\
\text { Oud }\end{array}$} & \multirow[b]{2}{*}{ Sexe } & \multicolumn{6}{|c|}{ Leefijdscategorie } & \multirow[b]{2}{*}{ Totaal } & \multirow[b]{2}{*}{$\begin{array}{l}\text { Inci- } \\
\text { dentia }\end{array}$} \\
\hline & & & 04 & $5-14$ & $15-24$ & $25-44$ & $45-64$ & $\geq 65$ & & \\
\hline Chalazion & $\begin{array}{l}\text { Nieuw } \\
\text { Oud }\end{array}$ & $\begin{array}{l}\text { Man } \\
\text { Vrouw } \\
\text { Totaal } \\
\text { Man } \\
\text { Vrouw } \\
\text { Totaal }\end{array}$ & & & & & 2 & 1 & 3 & 0.4 \\
\hline Hordcolum & $\begin{array}{l}\text { Nieuw } \\
\text { Ond }\end{array}$ & $\begin{array}{l}\text { Man } \\
\text { Vrouw } \\
\text { Totaal } \\
\text { Man } \\
\text { Vrouw } \\
\text { Totaal }\end{array}$ & & 4 & 5 & 5 & 7 & 2 & 23 & 3.4 \\
\hline Blefaritis & $\begin{array}{l}\text { Nieuw } \\
\text { Oud }\end{array}$ & $\begin{array}{l}\text { Man } \\
\text { Vrouw } \\
\text { Totaal } \\
\text { Man } \\
\text { Vrouw } \\
\text { Totaal }\end{array}$ & & $\begin{array}{l}4 \\
4\end{array}$ & $\begin{array}{l}2 \\
2\end{array}$ & $\begin{array}{l}2 \\
2\end{array}$ & $\begin{array}{l}1 \\
1\end{array}$ & $\begin{array}{l}1 \\
1\end{array}$ & $\begin{array}{r}1 \\
9 \\
10\end{array}$ & $\begin{array}{l}0.1 \\
2.7 \\
1.5\end{array}$ \\
\hline $\begin{array}{l}\text { Kalk- } \\
\text { konkrementen }\end{array}$ & $\begin{array}{l}\text { Nieuw } \\
\text { Ond }\end{array}$ & $\begin{array}{l}\text { Man } \\
\text { Vrouw } \\
\text { Totaal } \\
\text { Man } \\
\text { Vrouw } \\
\text { Total }\end{array}$ & & & & 1 & 3 & & 4 & 0.6 \\
\hline Trichiasis & $\begin{array}{l}\text { Nieuw } \\
\text { Oud }\end{array}$ & $\begin{array}{l}\text { Man } \\
\text { Vrouw } \\
\text { Totaal } \\
\text { Man } \\
\text { Vrouw } \\
\text { Totaal }\end{array}$ & & & & 1 & 2 & & 1 & 0.6 \\
\hline $\begin{array}{l}\text { Blefaritis } \\
\text { horpetica }\end{array}$ & $\begin{array}{l}\text { Nieuw } \\
\text { Oud }\end{array}$ & $\begin{array}{l}\text { Man } \\
\text { Vrouw } \\
\text { Totaal } \\
\text { Man } \\
\text { Vrouw } \\
\text { Totaal }\end{array}$ & & & & $\mathbb{1}$ & & & $\mathbb{1}$ & 0.1 \\
\hline $\begin{array}{l}\text { Oedeem } \\
\text { oogleden }\end{array}$ & $\begin{array}{l}\text { Nieuw } \\
\text { Oud }\end{array}$ & $\begin{array}{l}\text { Man } \\
\text { Vrouw } \\
\text { Totaal } \\
\text { Man } \\
\text { Vrouw } \\
\text { Totalal }\end{array}$ & & 1 & $\mathbb{1}$ & 3 & & & 5 & 0.7 \\
\hline
\end{tabular}




\begin{tabular}{|c|c|c|c|c|c|c|c|c|c|c|}
\hline \multirow[b]{2}{*}{ Aandioening } & \multirow[b]{2}{*}{$\begin{array}{l}\text { Nieuw- } \\
\text { Oud }\end{array}$} & \multirow[b]{2}{*}{ Sexe } & \multicolumn{6}{|c|}{ Leefujdscategorie } & \multirow[b]{2}{*}{ Totalal } & \multirow{2}{*}{$\begin{array}{l}\text { Inci } \\
\text { dentie }\end{array}$} \\
\hline & & & $0-4$ & $5-14$ & $15-24$ & $25-44$ & 4564 & $\geq 65$ & & \\
\hline $\begin{array}{l}\text { Neurodermitis } \\
\text { oogleden }\end{array}$ & $\begin{array}{l}\text { Nieuw } \\
\text { Oud }\end{array}$ & $\begin{array}{l}\text { Man } \\
\text { Vrouw } \\
\text { Totaal } \\
\text { Man } \\
\text { Vrouw } \\
\text { Totaal }\end{array}$ & & 1 & & 3 & 1 & 1 & 7 & 1.0 \\
\hline Entropion & $\begin{array}{l}\text { Nieuw } \\
\text { Oud }\end{array}$ & $\begin{array}{l}\text { Man } \\
\text { Vrouw } \\
\text { Totaal } \\
\text { Man } \\
\text { Vrouw } \\
\text { Totaal }\end{array}$ & & & & & & 1 & $\mathbb{1}$ & 0.1 \\
\hline $\begin{array}{l}\text { Niet- } \\
\text { aanliggende } \\
\text { traanpunten }\end{array}$ & $\begin{array}{l}\text { Nieuws } \\
\text { Oud }\end{array}$ & $\begin{array}{l}\text { Man } \\
\text { Vrouw } \\
\text { Totaal } \\
\text { Man } \\
\text { Vrouw } \\
\text { Totaall }\end{array}$ & & & & & & 2 & 2 & 0.3 \\
\hline $\begin{array}{l}\text { Stenosis } \\
\text { traanwegen }\end{array}$ & $\begin{array}{l}\text { Nieurw } \\
\text { Oud }\end{array}$ & $\begin{array}{l}\text { Man } \\
\text { Vrouw } \\
\text { Totaal } \\
\text { Man } \\
\text { Vrouw } \\
\text { Totaal }\end{array}$ & & & & & 1. & & 1 & 0.1 \\
\hline $\begin{array}{l}\text { Verminderde } \\
\text { traanproductie }\end{array}$ & $\begin{array}{l}\text { Nieuw } \\
\text { Oud }\end{array}$ & $\begin{array}{l}\text { Man } \\
\text { Vrouw } \\
\text { Totaal } \\
\text { Man } \\
\text { Vroury } \\
\text { Totaal }\end{array}$ & & & & & 4 & 2 & 6 & 0.9 \\
\hline $\begin{array}{l}\text { Subconjumctivale } \\
\text { bloeding }\end{array}$ & $\begin{array}{l}\text { Nieuw } \\
\text { Oud }\end{array}$ & $\begin{array}{l}\text { Man } \\
\text { Vrouw } \\
\text { Totaal } \\
\text { Man } \\
\text { Vrouw } \\
\text { Totaal }\end{array}$ & 1 & & 2 & & 2 & 1 & 6 & 0.9 \\
\hline $\begin{array}{l}\text { Bactriele } \\
\text { conjunctivitis }\end{array}$ & $\begin{array}{l}\text { Nieuw } \\
\text { Oud }\end{array}$ & $\begin{array}{l}\text { Man } \\
\text { Vrouw } \\
\text { Totaal } \\
\text { Man } \\
\text { Vrouw } \\
\text { Totaal }\end{array}$ & 5 & 8 & 3 & 4 & 1 & 1 & 22 & 3.2 \\
\hline
\end{tabular}




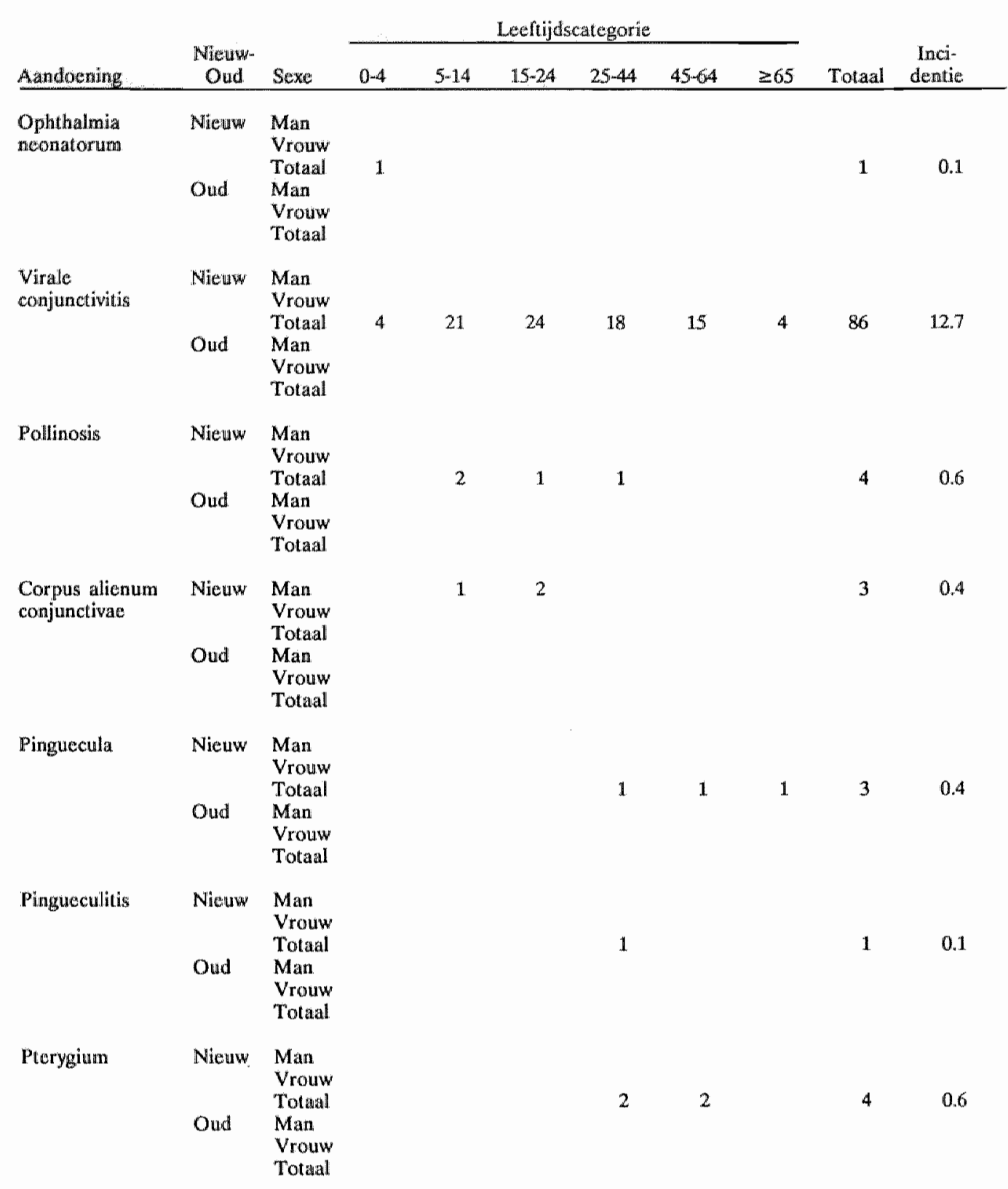




\begin{tabular}{|c|c|c|c|c|c|c|c|c|c|c|}
\hline \multirow[b]{2}{*}{ Agndoening } & \multirow[b]{2}{*}{$\begin{array}{l}\text { Nicuw- } \\
\text { Oud }\end{array}$} & \multirow[b]{2}{*}{ Sexe } & \multicolumn{6}{|c|}{ Leeftijdscategorie } & \multirow[b]{2}{*}{ Totainl } & \multirow{2}{*}{$\begin{array}{c}\text { Inci- } \\
\text { dentie }\end{array}$} \\
\hline & & & $0-4$ & $5-14$ & $15-24$ & $25-44$ & $45-64$ & $\geq 65$ & & \\
\hline $\begin{array}{l}\text { Tumor } \\
\text { conjunctivae }\end{array}$ & $\begin{array}{l}\text { Nieuw } \\
\text { Oud }\end{array}$ & $\begin{array}{l}\text { Man } \\
\text { Vrouw } \\
\text { Totaal } \\
\text { Man } \\
\text { Vrouw } \\
\text { Totaal }\end{array}$ & & & & 1 & & 1 & 2 & 0.3 \\
\hline $\begin{array}{l}\text { Keratitis } \\
\text { dendritica }\end{array}$ & $\begin{array}{l}\text { Nieuw } \\
\text { Oud }\end{array}$ & $\begin{array}{l}\text { Man } \\
\text { Vrouw } \\
\text { Totaal } \\
\text { Man } \\
\text { Vrouw } \\
\text { Totaal }\end{array}$ & & & & & 2 & & 2 & 0.3 \\
\hline $\begin{array}{l}\text { Keratitis } \\
\text { marginalis }\end{array}$ & $\begin{array}{l}\text { Nieuw } \\
\text { Oud }\end{array}$ & $\begin{array}{l}\text { Man } \\
\text { Vrouw } \\
\text { Totaall } \\
\text { Man } \\
\text { Vrouw } \\
\text { Totaal }\end{array}$ & & $\begin{array}{l}4 \\
4\end{array}$ & $\begin{array}{l}2 \\
2\end{array}$ & $\begin{array}{l}2 \\
1 \\
3\end{array}$ & $\begin{array}{l}1 \\
1 \\
2\end{array}$ & & $\begin{array}{r}3 \\
8 \\
11\end{array}$ & $\begin{array}{l}0.9 \\
2.4 \\
1.6\end{array}$ \\
\hline $\begin{array}{l}\text { Keratitis } \\
\text { electrica }\end{array}$ & $\begin{array}{l}\text { Nieuw } \\
\text { Oud }\end{array}$ & $\begin{array}{l}\text { Man } \\
\text { Vrouw } \\
\text { Totaal } \\
\text { Man } \\
\text { Vrouw } \\
\text { Totatal }\end{array}$ & & & & 1 & 1 & & 2 & 0.3 \\
\hline Erosie & $\begin{array}{l}\text { Nieuw } \\
\text { Ond }\end{array}$ & $\begin{array}{l}\text { Man } \\
\text { Vrouw } \\
\text { Totaal } \\
\text { Man } \\
\text { Vrouw } \\
\text { Totaal }\end{array}$ & 1 & & 1 & 9 & 3 & & 14 & 2.1 \\
\hline $\begin{array}{l}\text { Corpus alienum } \\
\text { /roestring } \\
\text { in corneam }\end{array}$ & $\begin{array}{l}\text { Nieuw } \\
\text { Oud }\end{array}$ & $\begin{array}{l}\text { Man } \\
\text { Vrouw } \\
\text { Totaal } \\
\text { Man } \\
\text { Vrouw } \\
\text { Totaal }\end{array}$ & & & & & 6 & 4 & 10 & 1.5 \\
\hline $\begin{array}{l}\text { Cornea- } \\
\text { pigmentaties }\end{array}$ & $\begin{array}{l}\text { Nieuw } \\
\text { Oud }\end{array}$ & $\begin{array}{l}\text { Man } \\
\text { Vrouw } \\
\text { Totaal } \\
\text { Man } \\
\text { Vrouw } \\
\text { Totaal }\end{array}$ & & & & & 1 & 2 & 3 & 0.4 \\
\hline
\end{tabular}




\begin{tabular}{|c|c|c|c|c|c|c|c|c|c|c|}
\hline \multirow[b]{2}{*}{ Aandotening } & \multirow{2}{*}{$\begin{array}{c}\text { Nieuw- } \\
\text { Oud }\end{array}$} & \multirow[b]{2}{*}{ Sexe } & \multicolumn{6}{|c|}{ Leeftijdscategorie } & \multirow[b]{2}{*}{ Totaal } & \multirow{2}{*}{$\begin{array}{l}\text { Inci: } \\
\text { dentie }\end{array}$} \\
\hline & & & $0-4$ & $5-14$ & $15-24$ & $25-44$ & $45-64$ & $\geq 65$ & & \\
\hline $\begin{array}{l}\text { Vaatingroei } \\
\text { cornea }\end{array}$ & $\begin{array}{l}\text { Nieurw } \\
\text { Oud }\end{array}$ & $\begin{array}{l}\text { Man } \\
\text { Vrouw } \\
\text { Totaal } \\
\text { Man } \\
\text { Vrouw } \\
\text { Totaal }\end{array}$ & & & 1 & & & & 1 & 0.1 \\
\hline $\begin{array}{l}\text { Keratitis } \\
\text { punctata }\end{array}$ & $\begin{array}{l}\text { Nieww } \\
\text { Oud }\end{array}$ & $\begin{array}{l}\text { Man } \\
\text { Vrouw } \\
\text { Totaal } \\
\text { Man } \\
\text { Vrouw } \\
\text { Totaal }\end{array}$ & & $\begin{array}{l}1 \\
1\end{array}$ & $\begin{array}{l}1 \\
2 \\
3\end{array}$ & $\begin{array}{l}3 \\
3\end{array}$ & $\begin{array}{l}1 \\
5 \\
6\end{array}$ & & $\begin{array}{r}3 \\
10 \\
13\end{array}$ & $\begin{array}{l}0.9 \\
3.0 \\
1.9\end{array}$ \\
\hline Episcleritis & $\begin{array}{l}\text { Nieuw } \\
\text { Oud }\end{array}$ & $\begin{array}{l}\text { Man } \\
\text { Vrouw } \\
\text { Totaal } \\
\text { Man } \\
\text { Vrouw } \\
\text { Totaal }\end{array}$ & 1 & & & & & & 1 & 0.1 \\
\hline $\begin{array}{l}\text { Acute } \\
\text { uveitis } \\
\text { anterior }\end{array}$ & $\begin{array}{l}\text { Nieuw } \\
\text { Oud }\end{array}$ & $\begin{array}{l}\text { Man } \\
\text { Vrouw } \\
\text { Totaal } \\
\text { Man } \\
\text { Vrouw } \\
\text { Totaal }\end{array}$ & & & & 2 & 1 & & 1 & 0.6 \\
\hline $\begin{array}{l}\text { Chronische } \\
\text { uweitis } \\
\text { posterior }\end{array}$ & $\begin{array}{l}\text { Nieuw } \\
\text { Oud. }\end{array}$ & $\begin{array}{l}\text { Man } \\
\text { Vrouw } \\
\text { Totaal } \\
\text { Man } \\
\text { Vrouw } \\
\text { Totaal }\end{array}$ & & & 1 & & 2 & & 3 & 0.4 \\
\hline $\begin{array}{l}\text { Metustasen } \\
\text { uvea }\end{array}$ & $\begin{array}{l}\text { Nieuw } \\
\text { Oud }\end{array}$ & $\begin{array}{l}\text { Man } \\
\text { Vrouw } \\
\text { Totaal } \\
\text { Man } \\
\text { Vrouw } \\
\text { Totaal }\end{array}$ & & & & & & 1 & 1 & 0.1 \\
\hline $\begin{array}{l}\text { Gering } \\
\text { cataract }\end{array}$ & Nieuw & $\begin{array}{l}\text { Man } \\
\text { Vrouw } \\
\text { Totaal } \\
\text { Man } \\
\text { Vrouw } \\
\text { Totaal }\end{array}$ & & & & $\begin{array}{l}1 \\
1\end{array}$ & $\begin{array}{l}4 \\
5 \\
9\end{array}$ & $\begin{array}{r}5 \\
12 \\
17\end{array}$ & $\begin{array}{r}9 \\
18 \\
27\end{array}$ & $\begin{array}{l}2.7 \\
5.3 \\
4\end{array}$ \\
\hline
\end{tabular}




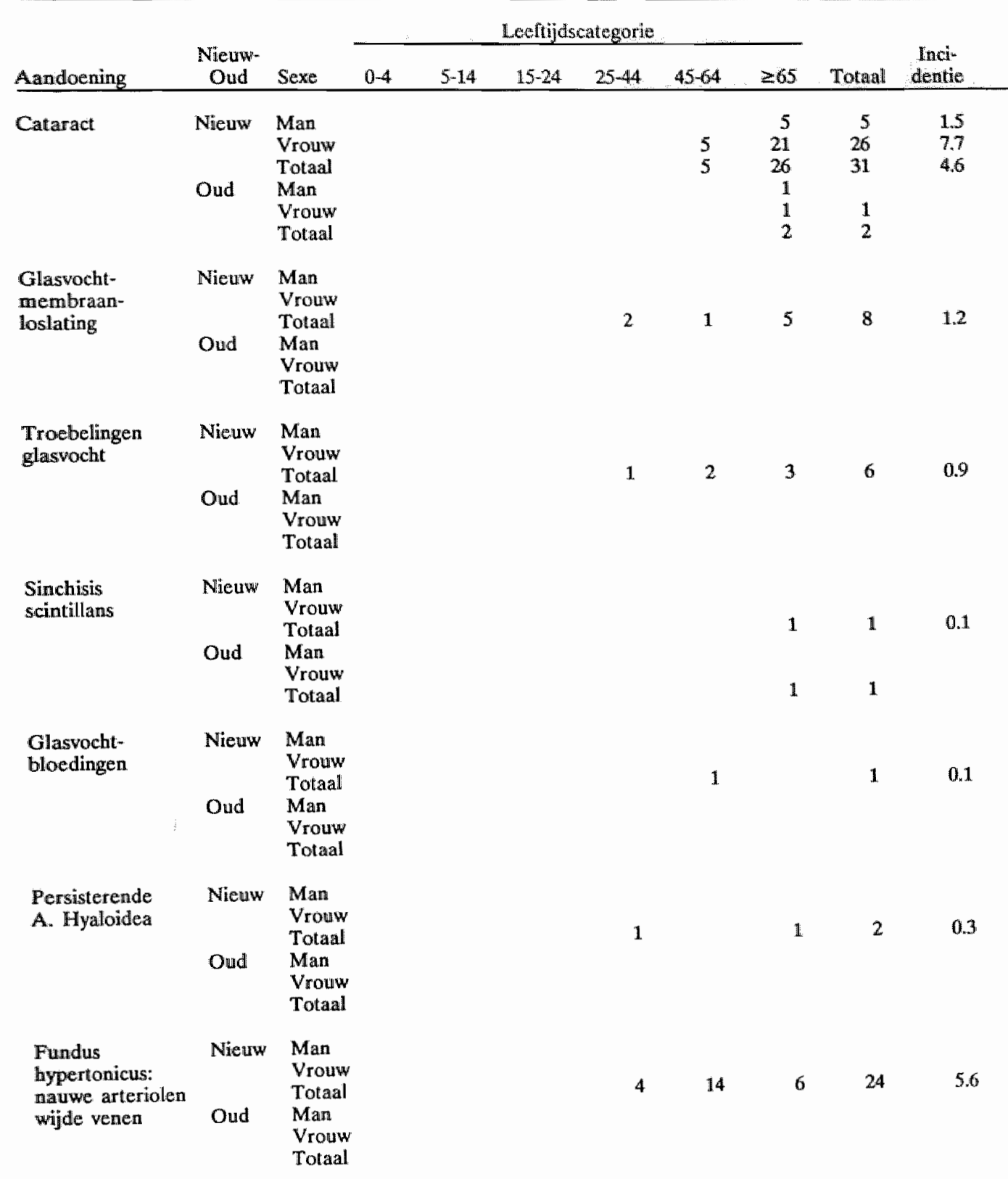




\begin{tabular}{|c|c|c|c|c|c|c|c|c|c|c|}
\hline \multirow[b]{2}{*}{ Aandoening } & \multirow[b]{2}{*}{$\begin{array}{l}\text { Nieuw- } \\
\text { Ouid }\end{array}$} & \multirow[b]{2}{*}{ Sexe } & \multicolumn{6}{|c|}{ Leefijdseategorie } & \multirow[b]{2}{*}{ Totaal } & \multirow[b]{2}{*}{$\begin{array}{c}\text { Inciw } \\
\text { dentie }\end{array}$} \\
\hline & & & $0-4$ & $5-14$ & $15-24$ & $25 \cdot 44$ & $45-64$ & $\geq 65$ & & \\
\hline $\begin{array}{l}\text { Pundus } \\
\text { lhypertonicus: } \\
\text { bloedingen }\end{array}$ & $\begin{array}{l}\text { Nieuw } \\
\text { Oud }\end{array}$ & $\begin{array}{l}\text { Man } \\
\text { Vrouw } \\
\text { Totalal } \\
\text { Man } \\
\text { Vrouw } \\
\text { Totaal }\end{array}$ & & & & & 1 & 4 & 8 & 1.2 \\
\hline $\begin{array}{l}\text { Fundus } \\
\text { hypertonicus: } \\
\text { cotton wools }\end{array}$ & $\begin{array}{l}\text { Nieuw } \\
\text { Ond }\end{array}$ & $\begin{array}{l}\text { Mant } \\
\text { Vrouw } \\
\text { Totalal } \\
\text { Man } \\
\text { Vrouw } \\
\text { Totalal }\end{array}$ & & & & & 1 & 1. & 2 & 0.3 \\
\hline $\begin{array}{l}\text { Diabetische } \\
\text { retinopathie: } \\
\text { microaneurysma }\end{array}$ & $\begin{array}{l}\text { Nieuw } \\
\text { Oud }\end{array}$ & $\begin{array}{l}\text { Man } \\
\text { Vrouw } \\
\text { Totaal } \\
\text { Man } \\
\text { Vrouw } \\
\text { Totaal }\end{array}$ & & & & & & 2 & 2 & 0.3 \\
\hline $\begin{array}{l}\text { Diabetische } \\
\text { retinopathie: } \\
\text { bloedingen en } \\
\text { exsudaten }\end{array}$ & $\begin{array}{l}\text { Nieuw } \\
\text { Oud }\end{array}$ & $\begin{array}{l}\text { Man } \\
\text { Vrouw } \\
\text { Totaal } \\
\text { Mant } \\
\text { Vrouw } \\
\text { Totaall }\end{array}$ & & & & & 1 & 1 & 1 & 0.4 \\
\hline $\begin{array}{l}\text { Diabetische } \\
\text { retinopathie: } \\
\text { vatprolife- } \\
\text { raties }\end{array}$ & $\begin{array}{l}\text { Nieuw } \\
\text { Oud }\end{array}$ & $\begin{array}{l}\text { Man } \\
\text { Vrouw } \\
\text { Totaal } \\
\text { Man } \\
\text { Vrouw } \\
\text { Totaal }\end{array}$ & & & & 1 & & & 1 & 0.1 \\
\hline $\begin{array}{l}\text { Fundus } \\
\text { arteriolo- } \\
\text { scleroticus: } \\
\text { bij overkruising } \\
\text { wene niet } \\
\text { transparant }\end{array}$ & $\begin{array}{l}\text { Nieuw } \\
\text { Oud }\end{array}$ & $\begin{array}{l}\text { Man } \\
\text { Vrouw } \\
\text { Totaal } \\
\text { Man } \\
\text { Vrouw } \\
\text { Totaal }\end{array}$ & & & & & 4 & 3 & 7 & 1.0 \\
\hline $\begin{array}{l}\text { Fundus } \\
\text { arteriolo- } \\
\text { scleroticus: } \\
\text { bij overkruising } \\
\text { indrukken } \\
\text { bloedtkollom }\end{array}$ & Nieuw & $\begin{array}{l}\text { Man } \\
\text { Vrouw } \\
\text { Totaal } \\
\text { Man } \\
\text { Vrouw } \\
\text { Totaal }\end{array}$ & & & & 1 & 2 & 1 & 4 & 0.6 \\
\hline
\end{tabular}




\begin{tabular}{|c|c|c|c|c|c|c|c|c|c|c|}
\hline \multirow[b]{2}{*}{ Aandoening } & \multirow[b]{2}{*}{$\begin{array}{c}\text { Nieuw- } \\
\text { Oud }\end{array}$} & \multirow[b]{2}{*}{ Sexe } & \multicolumn{6}{|c|}{ Leeftidscategorie } & \multirow[b]{2}{*}{ Totaal } & \multirow[b]{2}{*}{$\begin{array}{l}\text { Inci- } \\
\text { dentie }\end{array}$} \\
\hline & & & $0-4$ & $5-14$ & $15-24$ & $25-44$ & $45-64$ & $\geq 65$ & & \\
\hline $\begin{array}{l}\text { Fundus } \\
\text { arteriolo- } \\
\text { scleroticus: } \\
\text { zilverdraad- } \\
\text { arterien }\end{array}$ & $\begin{array}{l}\text { Nieuw } \\
\text { Oud }\end{array}$ & $\begin{array}{l}\text { Man } \\
\text { Vrouw } \\
\text { Totaal } \\
\text { Man } \\
\text { Vrouw } \\
\text { Totaal }\end{array}$ & & & & & 1 & 2 & 3 & 0.4 \\
\hline $\begin{array}{l}\text { Fundus } \\
\text { arteriolo- } \\
\text { scleroticus: } \\
\text { takafslunting } \\
\text { vena centralis } \\
\text { retinae }\end{array}$ & $\begin{array}{l}\text { Nicuws } \\
\text { Oud }\end{array}$ & $\begin{array}{l}\text { Man } \\
\text { Vrouw } \\
\text { Totaal } \\
\text { Man } \\
\text { Vrouw } \\
\text { Totaal }\end{array}$ & & & & & 3 & 1 & 4 & 0.6 \\
\hline $\begin{array}{l}\text { Andere } \\
\text { vaatpathologie } \\
\text { in fundo }\end{array}$ & $\begin{array}{l}\text { Nieuw } \\
\text { Oud }\end{array}$ & $\begin{array}{l}\text { Man } \\
\text { Vrouw } \\
\text { Totaal } \\
\text { Man } \\
\text { Vrouw } \\
\text { Totaal }\end{array}$ & & & & & 2 & 2 & 4 & 0.6 \\
\hline $\begin{array}{l}\text { Macula: } \\
\text { pigmentblad- } \\
\text { afwijkingen }\end{array}$ & $\begin{array}{l}\text { Nieuw } \\
\text { Oud }\end{array}$ & $\begin{array}{l}\text { Man } \\
\text { Vrouw } \\
\text { Totaal } \\
\text { Man } \\
\text { Vrouw } \\
\text { Totaal }\end{array}$ & & & & & 1 & 3 & 4 & 0.6 \\
\hline $\begin{array}{l}\text { Macula- } \\
\text { degeneratie }\end{array}$ & $\begin{array}{l}\text { Nieurw } \\
\text { Oud }\end{array}$ & $\begin{array}{l}\text { Man } \\
\text { Vrouw } \\
\text { Totaal } \\
\text { Man } \\
\text { Vrouw } \\
\text { Totaal }\end{array}$ & & & & & & 1 & $\begin{array}{l}1 \\
2\end{array}$ & 0.1 \\
\hline $\begin{array}{l}\text { Ved Drusen } \\
\text { in macula }\end{array}$ & $\begin{array}{l}\text { Nieuw } \\
\text { Oud }\end{array}$ & $\begin{array}{l}\text { Man } \\
\text { Vrouw } \\
\text { Totaal } \\
\text { Man } \\
\text { Vrouw } \\
\text { Tolad }\end{array}$ & & & & & 1. & 5 & 6 & 0.9 \\
\hline Papiloedeem & Nieuw & $\begin{array}{l}\text { Man } \\
\text { Vrouw } \\
\text { Tolaal } \\
\text { Man } \\
\text { Vrouw } \\
\text { Tolaal }\end{array}$ & & & & & 1 & & 1 & 0.1 \\
\hline
\end{tabular}




\begin{tabular}{|c|c|c|c|c|c|c|c|c|c|c|}
\hline \multirow[b]{2}{*}{ Aandoening } & \multirow[b]{2}{*}{$\begin{array}{c}\text { Nieaw } \\
\text { Oud }\end{array}$} & \multirow[b]{2}{*}{ Sexe } & \multicolumn{6}{|c|}{ Leeftijdscategorie } & \multirow[b]{2}{*}{ Totaal } & \multirow[b]{2}{*}{$\begin{array}{l}\text { Inci- } \\
\text { dentie }\end{array}$} \\
\hline & & & $0 \sim 4$ & $5-14$ & $15-24$ & $25-44$ & $45-64$ & $\geq 65$ & & \\
\hline Papilatrofie & $\begin{array}{l}\text { Nieuw } \\
\text { Oud }\end{array}$ & $\begin{array}{l}\text { Man } \\
\text { Vrouw } \\
\text { Totaal } \\
\text { Man } \\
\text { Vrouw } \\
\text { Totaal }\end{array}$ & & & 1 & & & & 1 & \\
\hline $\begin{array}{l}\text { Peripapillaire } \\
\text { atrofie }\end{array}$ & $\begin{array}{l}\text { Nieuw } \\
\text { Oud }\end{array}$ & $\begin{array}{l}\text { Man } \\
\text { Vrouw } \\
\text { Totaal } \\
\text { Man } \\
\text { Vrouw } \\
\text { Totaal }\end{array}$ & & & & $\mathbb{1}$ & 1 & 1 & 3 & 0.4 \\
\hline $\begin{array}{l}\text { Neuritis } \\
\text { optica }\end{array}$ & $\begin{array}{l}\text { Nieuw } \\
\text { Oud }\end{array}$ & $\begin{array}{l}\text { Man } \\
\text { Vrouw } \\
\text { Totaal } \\
\text { Man } \\
\text { Vrouw } \\
\text { Totaal }\end{array}$ & & & & $\mathbb{1}$ & & & 1 & \\
\hline $\begin{array}{l}\text { Misschien } \\
\text { glaucoom }\end{array}$ & $\begin{array}{l}\text { Nietuw } \\
\text { Oud }\end{array}$ & $\begin{array}{l}\text { Man } \\
\text { Vrouw } \\
\text { Totaal } \\
\text { Man } \\
\text { Vrouw } \\
\text { Totaal }\end{array}$ & & & & 3 & 11 & 9 & 23 & 3.4 \\
\hline $\begin{array}{l}\text { Waarschijnlijk } \\
\text { glaucoom }\end{array}$ & $\begin{array}{l}\text { Nieuw } \\
\text { Oud }\end{array}$ & $\begin{array}{l}\text { Man } \\
\text { Vrouw } \\
\text { Totaal } \\
\text { Man } \\
\text { Vroww } \\
\text { Totaal }\end{array}$ & & & & & 3 & 1 & 3 & 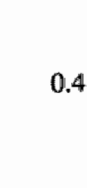 \\
\hline $\begin{array}{l}\text { Secundair } \\
\text { glatucoom }\end{array}$ & $\begin{array}{l}\text { Nieuw } \\
\text { Oud }\end{array}$ & $\begin{array}{l}\text { Man } \\
\text { Vrouw } \\
\text { Totaal } \\
\text { Man } \\
\text { Vrouw } \\
\text { Totaal }\end{array}$ & & & & & 1 & & 1 & 0.1 \\
\hline Amblyopie & $\begin{array}{l}\text { Nieuw } \\
\text { Oud }\end{array}$ & $\begin{array}{l}\text { Man } \\
\text { Vrouw } \\
\text { Totaal } \\
\text { Man } \\
\text { Vrouw } \\
\text { Totaal }\end{array}$ & & & $\begin{array}{l}2 \\
2\end{array}$ & $\begin{array}{l}1 \\
1 \\
2\end{array}$ & $\begin{array}{l}2 \\
2\end{array}$ & & $\begin{array}{l}5 \\
1 \\
6\end{array}$ & \\
\hline
\end{tabular}




\section{Bijlage VI}

\section{Restcategorie behorend bij tabel 7.2.- 1, 7.2.- 2 en 7.2.- 3}

Aandoeningen uit de eigen registratie behorend tot de restcategorie van tabel 7.2.1 (vergelijking met Oliemans en Nijmegen).

Aandoening

challazion

$\begin{array}{ll}\text { kalkconcrementen in conjunctiva } & 0.4 \\ & 0.6\end{array}$

$\begin{array}{ll}\text { trichiasis } & 0.6\end{array}$

entropion $\quad 0.1$

niet-aanliggende traanpunten $\quad 0.3$

$\begin{array}{ll}\text { sicca-syndroom } & 0.9\end{array}$

subconjunctivale bloeding $\quad 0.9$

tumor conjunctivae $\quad 0.3$

$\begin{array}{ll}\text { erosic } & 2.1\end{array}$

$\begin{array}{ll}\text { vaatingroei cornea } & 0.1\end{array}$

metastasen uvea $\quad 0.1$

glasvochtmembraamloslating $\quad 1.2$

troebelingen glaswocht $\quad 0.9$

sinchisis scintillans $\quad 0.1$

glasvochtbloeding $\quad 0.1$

fundus hypertonicus graad 1,2,3 7.1

diabetische retinopathie graad $1,2,3 \quad 0.8$

vaatsclerose graad $1,2,3,4 \quad 2.6$

andere vaatpathologie in fundo $\quad 0,6$

macula:pigmentveranderingen $\quad 0.6$

maculadegeneratie $\quad 0.1$

veel Drusen in macula $\quad 0.3$

papiloedeem $\quad 0.1$

peripapillaire atrofre $\quad 0.4$

Totaal restcattegorie incidentie

21.7

Restcategorie Oliemans (incidentie 3.7) en Nijmegen (incidentie 23.5):

corneatroebeling

conj bloeding

chalazion

ec/entropion

blindheid aan een of twee ogen 
Aandoeningen uit de eigen registratie behorend tot de restcategorie van tabel 7.2.- 2 (vergelijking met Lamberts).

Aaardoening

latent strabisme $\quad 0.1$

strabisme $\quad 0.3$

strabismus paralyticus 0.1

kalkconcrementen in conjunctiva $\quad 0.6$

$\begin{array}{ll}\text { trichiasis } & 0.6\end{array}$

entropion 0.1

niet-aanliggende traanpunten $\quad 0.3$

viccasyndroom 0.9

subconjunctivale bloeding $\quad 0.9$

tumor conjunctivae $\quad 0.3$

keratitus dendritica $\quad 0.3$

randulcera corneace $\quad 1.6$

keratitis electrica 0.3

erosie 2.1

vaatingroei cornea 0.1

$\begin{array}{lr}\text { keratitis punctata } & 1.9\end{array}$

$\begin{array}{ll}\text { episcleritis } & 0.1\end{array}$

acute uveitis anterior $\quad 0.6$

metastasen uvea $\quad 0.1$

glasvochtmembraanloslating 1.2

troebelimgen glaswocht $\quad 0.9$

sinchisis scintillans 0.1

glaswochtbloeding 0.1

fundus hypertonicus graad 1,2,3

diabetische retinopathie graad 1,2,3 0.8

vaatsclerose graad $1,2,3,4 \quad 2.6$

andere vaatpathologie in fundo $\quad 0.6$

macula:pigmentveranderingen $\quad 0.6$

maculadegeneratie $\quad 0.1$

veel Drusen in macula 0.9

papiloedeem 0.1

peripapillaire atrolie $\quad 0.4$

$\begin{array}{ll}\text { Totaal restcategorie } & 26.8\end{array}$

Lamberts: incidentie "andere oogziekten" $6.3-6.6$ 
Aandoeningen uit de eigen registratie behorend tot de restcategorie van tabel 7.2.- 3 (vergelijking met Hodgkin).

Aandoening

$\begin{array}{ll}\text { chalazion } & 0.4 \\ \text { kalkconcrementen in conjunctiva } & 0.6 \\ \text { trichiasis } & 0.6 \\ \text { entropion } & 0.1 \\ \text { niet-aanliggende traanpunten } & 0.3 \\ \text { sicca syndroom } & 0.9 \\ \text { corpus alienun conjunctivae } & 0.4 \\ \text { tumor conjunctivae } & 0.3 \\ \text { keratitis dendritica } & 0.3 \\ \text { erosie } & 2.1 \\ \text { copus alienum corneae } & 1.5 \\ \text { vaatingroei cornea } & 0.1 \\ \text { keratitis punctata } & 1.9 \\ \text { episcleritis } & 0.1 \\ \text { metastasen uvea } & 0.1 \\ \text { glaswochtmembraanloslating } & 1.2 \\ \text { troebelingen glaswocht } & 0.9 \\ \text { sinchisis scintillans } & 0.1 \\ \text { fundus hypertonicus graad 1,2,3 } & 7.1 \\ \text { diabetische retinopathie graad } 1,2,3 & 0.8 \\ \text { vaatsclerase graad } 1,2,3,4 & 2.6 \\ \text { andere vaatpathologie in fundo } & 0.6 \\ \text { macula:pigmentveranderingen } & 0.6 \\ \text { maculadegeneratie } & 0.1 \\ \text { veel Drusen in macula } & 0.9 \\ \text { papiloedeem } & 0.1 \\ \text { peripapillaire atrofie } & 0.4\end{array}$

Totaal restcategoric

geen restcategorie bij Hodgkin 


\section{Curriculum vitae}

Josephus Leonardus Baggen werd 8 october 1929 geboren te Schinveld. Hij behaalde in 1950 het Gymnasium B diploma aan het Bernardinuscollege te Heerlen. Na twee jaar militaire dienst doorliep hij de medische opleiding aan de Rooms Katholieke Universiteit te Nijmegen welke in 1961 werd afgesloten met het behalen wan het artsexamen. Zowel tijdens als na de geneeskundige opleiding werd tevens studie gemaakt van de filosofie en de culturele antropologie, met name van de medische richting hierbinnen. $\mathrm{Na}$ een half jaar waarnemingen in verschillende huisartspraktijken vestigde hij zich op 1 october 1961 als solist-huisarts te Brunssum, waar hij in januari 1978 associeerde met M.H.J.Vaessen. Vanaf 1975 is hij als huisartsopleider verbonden aan de huisartsopleiding van de Rijksuniversiteit Limburg en sinds 1987 tevens als huisarts-docent. 